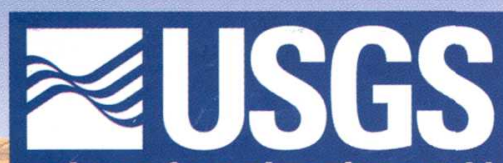

science for a changing world

Prepared in cooperation with the $12118 / 98$

KANSAS WATER OFFICE

\title{
Effects of Water-Budget Components on Streamflow in the Republican River from Near Hardy, Nebraska, to Concordia, Kansas, October 1980-September 1995
}

Water-Resources Investigations Report 98-4163

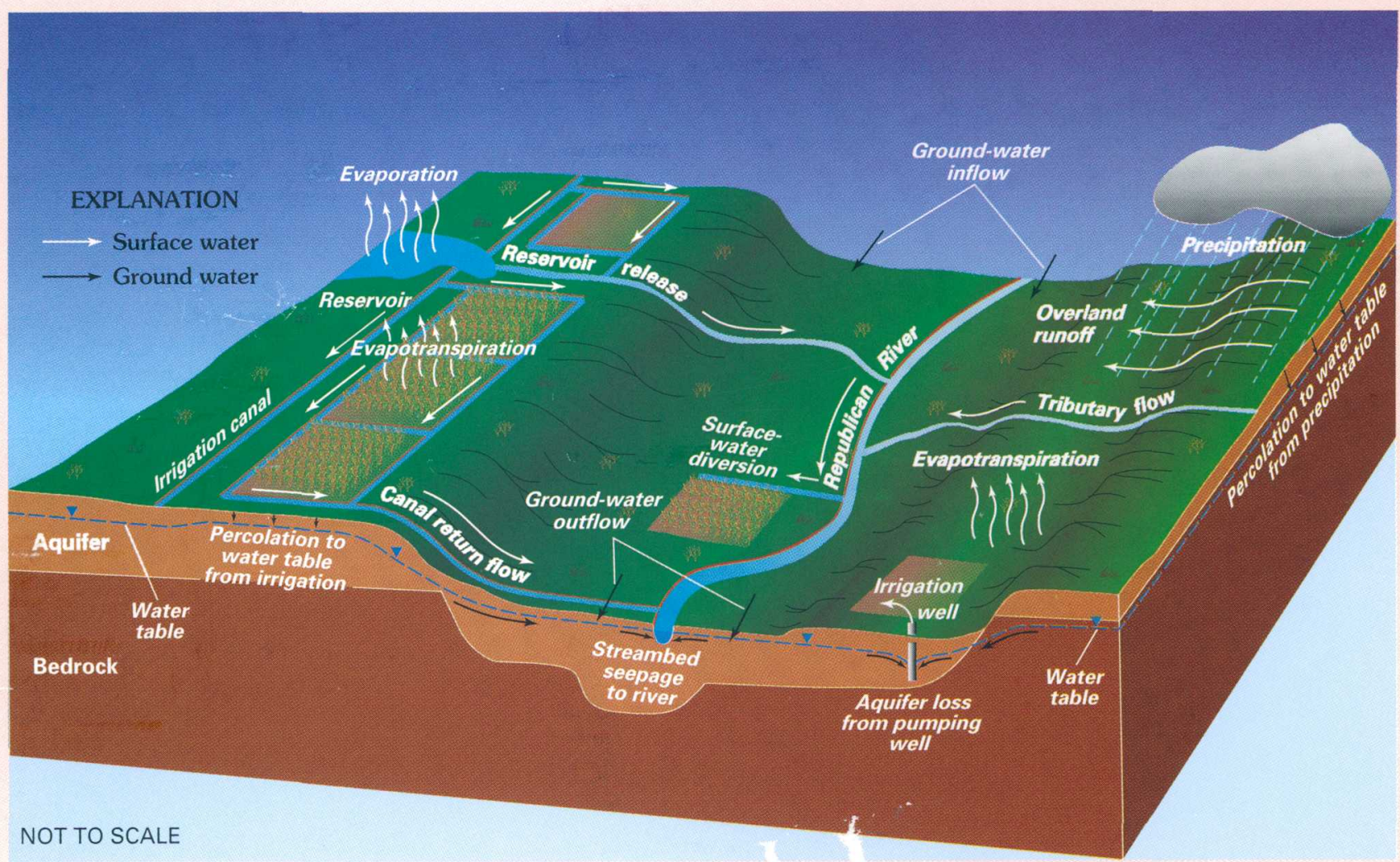


Prepared in cooperation with the

KANSAS WATER OFFICE

\title{
Effects of Water-Budget Components on Streamflow in the Republican River From Near Hardy, Nebraska, to Concordia, Kansas, October 1980-September 1995
}

\author{
By Cristi V. Hansen
}

Water-Resources Investigations Report 98-4163

Lawrence, Kansas

1998 


\section{U.S. Department of the Interior}

Bruce Babbitt, Secretary

\section{U.S. Geological Survey}

Thomas J. Casadevall, Acting Director

For additional information write to:

District Chief

U.S. Geological Survey 4821 Quail Crest Place

Lawrence, KS 66049-3839
Copies of this report can be purchased from:

U.S. Geological Survey

Information Services

Box 25286

Federal Center

Denver, CO 80225-0826 


\section{CONTENTS}

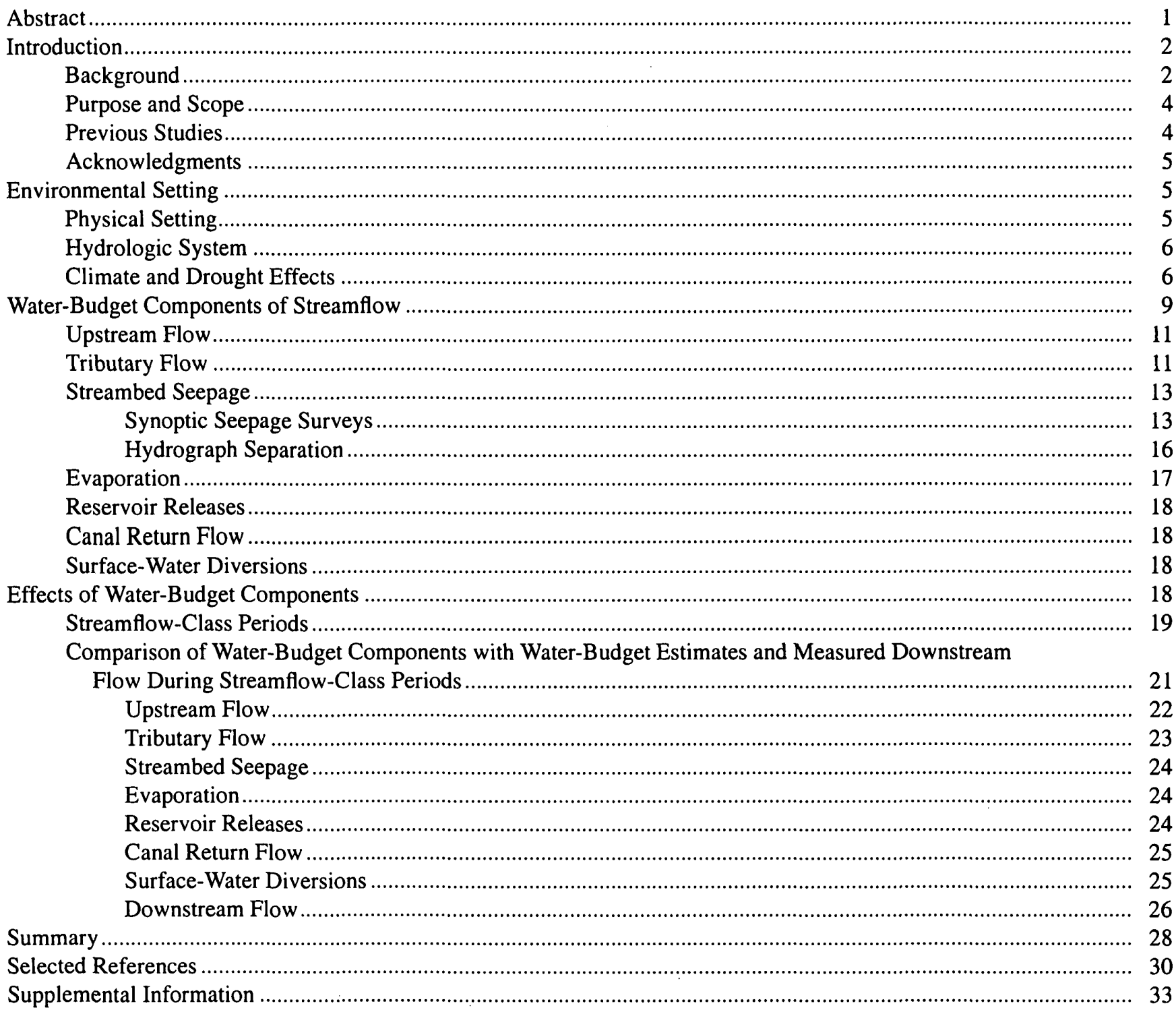

\section{FIGURES}

1. Maps showing location of Republican River, streamflow-gaging stations, and synoptic seepage-survey sites in study area, north-central Kansas

2. Diagram showing conceptualized hydrologic system and components of flow in study area.................................6

3-10. Graphs showing:

3. Precipitation at Concordia, Kansas; gaged streamflow of Republican River near Hardy, Nebraska; gaged streamflow at Concordia, Kansas; streamflow gain in Republican River from near Hardy, Nebraska, to Concordia, Kansas; evaporation at Lovewell Reservoir, Kansas; and periods of significant droughts and floods in north-central Kansas, October 1932-September 1996

4. Monthly precipitation and gaged streamflow at Concordia, Kansas, October 1951-September 1957 and October 1987-September 1992 
5. Comparison of measured and estimated streamflow at gaging station on Buffalo Creek near Jamestown, Kansas, July 1959-June 1990

6. Instantaneous streamflow measured at synoptic seepage-survey sites along Republican River in study area, 1982 and 1995-97.

7. Comparison of measured streamflow at Concordia, Kansas, during 1982 and 1995-97 with streambed seepage estimated from synoptic seepage-survey data

8. Comparison of streambed seepage estimated using data from 10 synoptic seepage surveys during 1982 and 1995-97 with streambed seepage estimated using BFI4 computer program

9. Monthly precipitation, estimated and measured streamflow, and difference between estimated and measured streamflow by volume and percent at Concordia, Kansas, and Palmer Modified Drought Severity Index for north-central Kansas, with example streamflow-class periods, October 1980-September 1995

10. Comparison of measured streamflow with water-budget estimates of streamflow in Republican River at Concordia, Kansas, October 1980-September 1995

\section{TABLES}

1. Comparison of average annual precipitation, streamflow, and canal return flow in the Republican River in the study area and average annual surface-water diversions and reservoir releases upstream from the study area during six selected reference periods

2. Synoptic seepage-survey measurements during 1982 and 1995-97

3. Average monthly precipitation, estimated water-budget components, and measured and estimated downstream flow for example streamflow-class periods, October 1980-September 1995

4. Average monthly and annual precipitation at Concordia, Kansas, and streamflow near Hardy, Nebraska, and at Concordia, Kansas, during October 1951-September 1995 and October 1980-September 1995

5. Monthly, monthly average for water years, and average monthly water-budget estimates of components of flow and of streamflow in the Republican River from near Hardy, Nebraska, to Concordia, Kansas, compared to measured downstream flow, minimum desirable streamflow, and precipitation at Concordia, Kansas, October 1980-September 1995

CONVERSION FACTORS, ABBREVIATIONS, AND VERTICAL DATUM

\begin{tabular}{rll}
\hline \multicolumn{1}{c}{ acre } & By & \multicolumn{1}{c}{ To obtain } \\
\hline acre-foot (acre-ft) & 1,233 & square meter \\
cubic meter \\
acre-foot per month (acre-ft/mo) & 1,233 & cubic meter per month \\
acre-foot per year (acre-ft/yr) & 1,233 & cubic meter per year \\
cubic foot per second $\left(\mathrm{ft}^{3} / \mathrm{s}\right)$ & 0.02832 & cubic meter per second \\
foot (ft) & 0.3048 & meter \\
inch (in.) & 25.4 & millimeter \\
inch per month (in/mo) & 25.4 & millimeter per month \\
inch per year (in/yr) & 25.4 & millimeter per year \\
mile $(\mathrm{mi})$ & 1.609 & kilometer \\
square mile $\left(\mathrm{mi}^{2}\right)$ & 2.590 & square kilometer \\
\hline
\end{tabular}

Sea level: In this report, "sea level" refers to the National Geodetic Vertical Datum of 1929-a geodetic datum derived from a general adjustment of the first-order level nets of the United States and Canada, formerly called Sea Level Datum of 1929.

Water year: Water year is the 12 -month period October 1 through September 30 . The water year is designated by the calendar year in which it ends. Thus, the year ending September 1995 is called the " 1995 water year." 


\title{
Effects of Water-Budget Components on Streamflow in the Republican River From Near Hardy, Nebraska, to Concordia, Kansas, October 1980-September 1995
}

\author{
By Cristi V. Hansen
}

\section{Abstract}

Kansas, Nebraska, and Colorado formed the Republican River Compact in 1942 to allocate the available water in the Republican River Basin among the three States. Greatly increased water use, beginning in the 1950's, has caused concern by the State of Kansas regarding the compliance of the compact conditions by Nebraska, the maintenance of streamflow above the minimum desirable streamflow at Concordia, Kansas, and the ensurance of an adequate water supply in Milford Lake to fulfill the needs of downstream users. This report describes the effects of major waterbudget components on streamflow in the Republican River from near Hardy, Nebraska, to Concordia, Kansas, for October 1980 through September 1995.

Upstream flow into the study reach, tributary flow, streambed seepage, evaporation, reservoir releases, irrigation canal return flow, and surfacewater diversions were considered major waterbudget components in a mass-balance model. Monthly water-budget estimates were compared to measured discharge of the Republican River at Concordia during high-flow, normal-flow, lowflow, and extreme low-flow conditions to quantify how well the water-budget estimates matched measured flows.

Components of streamflow that are less affected by human activity within the study area (upstream flow, tributary flow, streambed seepage, and evaporation) typically contribute the largest part of the water budget—averaging about 94 percent of the monthly water budget for October 1980 through September 1995 when combined. This combined percentage is relatively constant, ranging from 91 percent during the high-flow period to about 101 percent during the extreme low-flow period. Upstream flow generally is the largest contributor to the water budget, and its relative contribution tends to increase during lower flow periods. The importance of tributary flow tends to increase as streamflow increases and may become insignificant during a drought. Streambed seepage generally is positive, indicating that the Republican River is typically a gaining stream. Streambed seepage typically increases in importance as streamflow decreases; however, during times of drought, it may become negative, indicating that the river is a losing stream. Evaporation from the Republican River, while commonly less than 1 percent of the water budget, can become important during periods of drought.

Components of streamflow that are more affected by human activity in the study area (reservoir releases, canal return flow, and surfacewater diversions) collectively were generally a small proportion of the water budget, averaging about 6 percent when combined for October 1980 through September 1995, and generally resulted in a small net increase in the amount of water in the budget. Individually, components that are more affected by human activity within the study area can become important, especially during 
periods of extreme low flow within the irrigation season. During those periods, they collectively may either contribute to or remove a substantial percentage from the water budget.

Downstream flow provides a measure of how well the water-budget estimates compared to measured streamflow at Concordia, Kansas. The water budget tended to overestimate measured downstream flow by an average of about 10 percent. This general tendency to overestimation probably can be attributed mostly to overestimates of the streambed-seepage and tributaryflow components. The other water-budget components may have caused smaller errors in the water-budget estimates of downstream flow.

\section{INTRODUCTION}

In 1942, Kansas, Nebraska, and Colorado formed the Republican River Compact to allocate the available water in the Republican River Basin among the three States. Greatly increased water use, beginning in the 1950's, has caused concern by the State of Kansas regarding the compliance with the compact conditions by Nebraska, particularly during decreased flow conditions. This concern has generated a heightened interest in understanding the various components that contribute to Republican River streamflow from the Nebraska State line to Concordia, Kansas (fig.1), where a minimum desirable streamflow (MDS) has been established (Kansas law K.S.A. 82a-703a, 1984). Also of concern is the need to ensure an adequate water supply in Milford Lake to fulfill the instream uses and industrial, municipal, and agricultural needs of downstream users. To help address these regional concerns and increase the knowledge of ground- and surface-water interaction in the Republican River Valley (fig. 1), a 4-year (1994-97) study by the U.S. Geological Survey (USGS), in cooperation with the Kansas Water Office (KWO) and funded in part by the Kansas State Water Plan Fund, was designed to identify and quantify the interaction of the surface- and ground-water systems and their effects on streamflow in the Republican River in the study area, which includes the drainage basin of that part of the Republican River from near Hardy, Nebraska, to Concordia, Kansas (fig. 1).

\section{Background}

Following the droughts and floods of the 1930's, the Bureau of Reclamation (BOR, U.S. Department of the Interior) and U.S. Army Corps of Engineers began construction of a series of dams and surface-water irrigation networks intended to reduce flooding and to provide water for agriculture in the Republican River Basin. Before the completion of Harlan County Dam in November 1951 and Lovewell Reservoir in 1957, floods were an almost annual occurrence in the area. Precipitation was the only source of water for crops in much of the study area until the Kansas Bostwick Irrigation District (KBID), which was built by BOR, began full operation in 1958 . The KBID receives most of its water from requested releases from Harlan County Dam in Nebraska (fig. 1); water generally is not released from Harlan County Dam unless it is requested by an irrigation district, precipitation is plentiful, or in anticipation of increased runoff the following spring.

Water released for the KBID flows down the Republican River and is diverted at Guide Rock, Nebraska, into the Courtland Canal (diversion dam completed in 1952), which transports the water to Lovewell Reservoir in Kansas (fig. 1). Water generally is not released from Lovewell Reservoir unless it is requested by the $\mathrm{KBID}$, precipitation is plentiful, or in anticipation of increased runoff the following spring. Water released from Lovewell Reservoir for use by the KBID is distributed by a network of canals that begin just upstream from the USGS streamflow-gaging station on White Rock Creek at Lovewell (site 6, fig. 1). About 94 percent of the land irrigable by the KBID is located in the uplands west of the Republican River and in part of the valley east of the river (fig. 1); about 6 percent of the land irrigable by KBID is north (upstream) from the study area. The amount of land that can be irrigated by KBID is limited (fig. 1), mostly because the majority of the distribution system is gravity fed.

Beginning in the 1960's, the development of center-pivot and other mechanized sprinkler systems, which allow the irrigation of rolling farmland and growth on more acres of a greater variety of crops with larger water demands (for example, corn and alfalfa), encouraged an increase in both surface- and groundwater use for irrigation within and upstream from the study area.

In 1991, during the drought of 1988-92, flow in the Republican River decreased below the minimum 


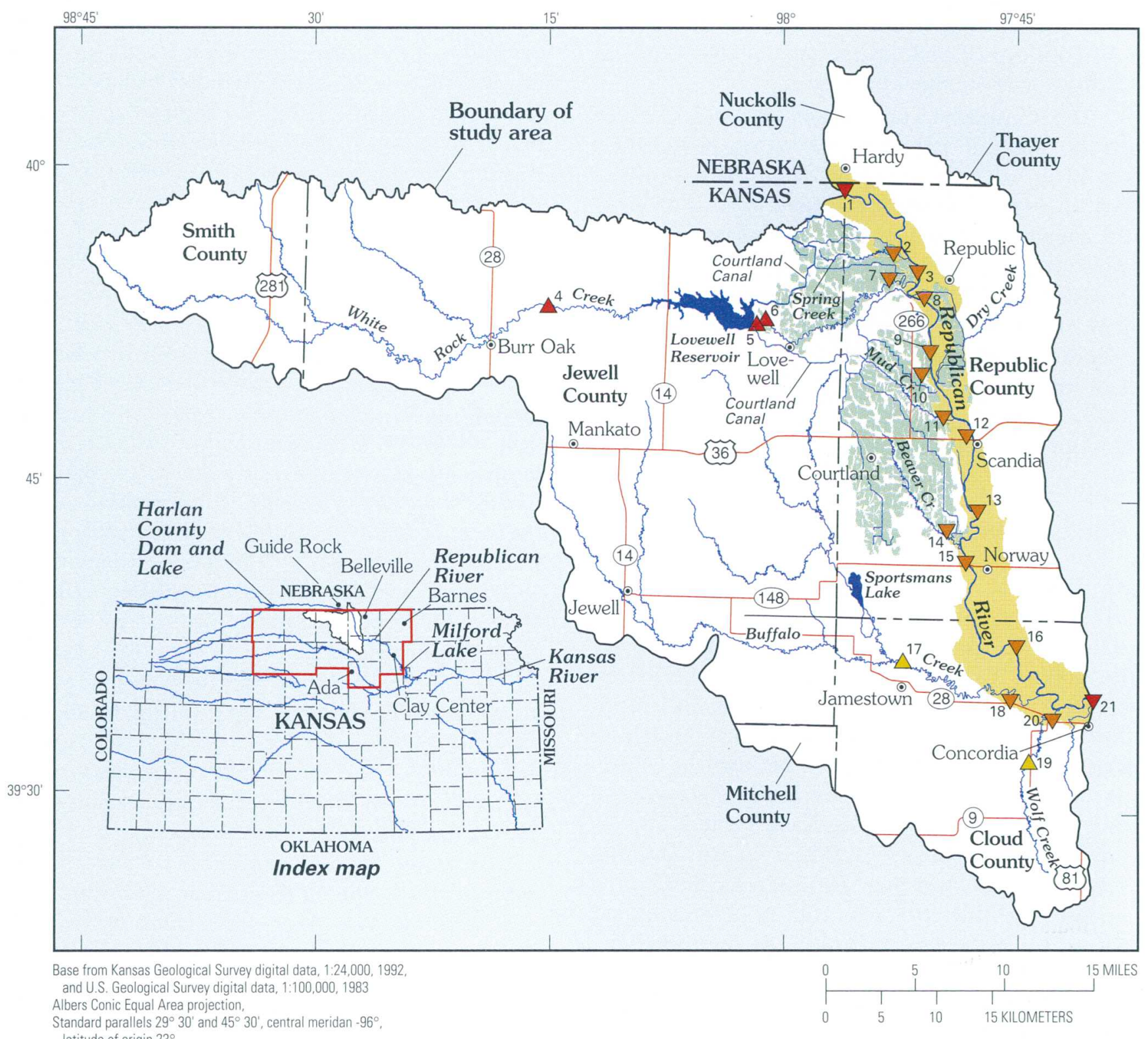

EXPLANATION

Republican River Valley

Land irrigated by Kansas Bostwick Irrigation District (KBID)

- Boundary of area (on index map) used to compute drought indices depicted in figure $3 \mathrm{~F}$ $\nabla^{1}$ U.S. Geological Survey streamflow-gaging station, synoptic seepage-survey site, and site number

$\Delta^{4} \quad$ U.S. Geological Survey streamflow-gaging station and site number

$\nabla^{12}$ Synoptic seepage-survey site and site number

$\triangle^{17}$ Discontinued U.S. Geological Survey streamflowgaging station and site number

Figure 1. Location of Republican River, streamflow-gaging stations, and synoptic seepage-survey sites in study area, northcentral Kansas.

desirable streamflow (MDS) requirement at Concordia, Kansas (established by Kansas law K.S.A. 82a-703a); this caused the DWR to attempt to increase the amount of streamflow in the Republican River by prohibiting about 100 junior permit holders from pumping water from the streams and 
hydraulically connected alluvium in the Republican River Valley in Cloud, Jewell, and Republic Counties during January through June 1992.

DWR instituted a moratorium on permits for new ground- and surface-water diversions in the Republican River Valley beginning in March 1990 because of concern regarding Republican River flow. Although the moratorium ended in April 1993 when new basinwide water-appropriation regulations for the Republican River [K.A.R. 5-3-11 (b) (9)] went into effect, no new permits have been approved since then because, according to these new regulations, all ground and surface water in the Republican River Valley was already fully appropriated (Matt Scherer, Division of Water Resources, written commun., 1998).

\section{Purpose and Scope}

The purpose of this report is to present the results of the 4-year study to quantify the effects of major water-budget components on streamflow in the Republican River from near Hardy, Nebraska, to Concordia, Kansas, for October 1980 through September 1995. The study area includes the drainage basin of that part of the Republican River between the USGS streamflow-gaging stations near Hardy, Nebraska (site 1, fig. 1), and Concordia, Kansas (site 21, fig. 1), and covers approximately $1,155 \mathrm{mi}^{2}$ in parts of Cloud, Jewell, Mitchell, Republic, and Smith Counties in north-central Kansas and a small part of Nuckolls and Thayer Counties in Nebraska (fig. 1). The period of October 1980 through September 1995 was chosen for evaluation because hydrologic and water-use data available for this period are superior to those of earlier times and because this period includes a variety of climatic conditions.

Upstream flow into the study reach, tributary inflow, streambed seepage, evaporation, reservoir releases, irrigation canal return flow, and surfacewater diversions were considered the major waterbudget components for this study. In this report, the emphasis is on streamflow in the Republican River itself, the contributions the river receives from other surface-water sources (tributary streams and canals), the seepage that takes place between the river and the adjacent aquifer, evaporation from the river, and the surface-water diversions that occur in the ungaged part of the study area between the gaging stations near Hardy, Nebraska, and at Concordia, Kansas. Because of this emphasis, the complexity of that part of the sur- face-water system in the study area upstream from the streamflow-gaging stations at White Rock Creek at Lovewell (site 6, fig. 1) and Buffalo Creek near Jamestown (site 17, fig. 1) was simplified to its contribution to the flow in the Republican River-which was considered to be the discharge at these two gaging stations and the canal return flow measured by the KBID.

Monthly water-budget estimates were compared to measured discharge of the Republican River at Concordia during high-flow, normal-flow, low-flow, and extreme low-flow conditions to quantify how well the estimated water-budget components matched measured flows. The proportion that each major component contributed to the water-budget estimates during these flow conditions was quantified by comparing monthly estimates of the major components to those of the water budget. The monthly major-component and water-budget estimates were quantified using measured or reported data available from BOR, KBID, DWR, USGS, and the National Oceanic and Atmospheric Administration.

Also included in this report are the results of 10 synoptic seepage surveys made along the Republican River and its major tributaries (fig. 1) during 1982 and 1995-97. These measurements were made to gain an improved understanding of streambed seepage to and from ground water in the study area.

The increasing public interest in the allocation of water in the Republican River Basin makes this study of regional importance because it addresses the need for more knowledge of the components of streamflow in the Republican River and of ground- and surfacewater interaction in the Republican River Valley required for the wise management of water resources of the region.

\section{Previous Studies}

Numerous reports on the geology and hydrology of all or parts of the study area have been written during the last 70 years. Wing (1930), in his report on the geology of Cloud and Republic Counties, included a short section on the availability of surface-water supplies in the study area. The ground- and surface-water concerns and water-supply potential of the lower Republican River Basin in Kansas in about 1960 were discussed in a report by the Kansas Water Resources Board (1961). Spruill (1985) described the condition of the surface-water system in 1982 for part of the 
lower Republican River Valley in Kansas upstream from Norway in Republic County. In 1994, under contract to KWO, Water Resources Management, Inc. (1994), completed a study of streamflow depletion in the surface-water system of the lower Republican River. Estimates of the major components of streamflow in the Republican River were made by Hansen (1997) using a preliminary version of the water budget developed for this study.

Since 1981 there have been several comprehensive studies of the Republican River Basin that include the study area. The Missouri Basin States Association (1982a,b) completed a comprehensive study of the surface- and ground-water systems in the Missouri Basin. BOR has completed two comprehensive studies-the first was a water-management study of the ground- and surface-water systems of the Republican River Basin that included the results of a numerical ground-water flow model (Bureau of Reclamation, $1985 \mathrm{a}, \mathrm{b}, \mathrm{c})$; the second was a resource-management study of the ground-and surface-water systems in the Republican River Basin that emphasized that part of the surface-water system controlled by BOR (Bureau of Reclamation, 1996).

\section{Acknowledgments}

Several agencies provided data used in this study. The Kansas Bostwick Irrigation District provided detailed data for 1975-95 on water use and discharge from the irrigation district, a map of the land and canals within the irrigation district, and information pertaining to operation of the irrigation district. The Bureau of Reclamation provided 1951-95 data on water use and discharge from the Kansas Bostwick Irrigation District and the Bostwick Irrigation District in Nebraska. The Kansas Department of Agriculture, Division of Water Resources, provided data on surface-water diversions. The Kansas Water Office periodically reviewed the study results and offered helpful suggestions.

\section{ENVIRONMENTAL SETTING}

More than 99 percent of the land in the study area is classified as rural (Helyar, 1996), and most of the regional economy is dependent on raising crops and livestock. The variability and the lack of precipitation during some years have led to poor crop yields or crop failures in the study area. The increased availability of water for irrigation due to developments such as operation of KBID, rolling sprinkler systems, and larger, more efficient pumps, has moderated, but not eliminated, many of the negative effects of drought on the local economy. About 40,000 of the approximately 42,500 irrigable acres within the KBID are in the study area; however, not all acres are irrigated every year.

\section{Physical Setting}

The study area is in the Plains Border section of the Great Plains physiographic province, which is characterized by plateaus that are submaturely to maturely dissected (Fenneman, 1931). The major geographic features in the study area are the Republican River, its valley, and the flat to gently rolling uplands that are to the east and west of the valley and about 200 to $250 \mathrm{ft}$ above the valley floor. The Republican River in the study area is about $43 \mathrm{mi}$ long between the gaging stations near Hardy, Nebraska (site 1, fig. 1), and at Concordia, Kansas (site 21, fig.1). The valley in the study area is about $34 \mathrm{mi}$ long and about 1 to $4.5 \mathrm{mi}$ wide.

Only a small part of the study area lies to the east of the Republican River. The tributaries there are small and dry for most of the year. To the west of the Republican River, the drainage area is larger, and most tributaries are larger (fig. 1). White Rock Creek and Buffalo Creek (fig. 1) are the two main tributaries in the study area; other important tributaries west of the Republican River are Spring, Mud, Beaver, and Wolf Creeks (from north to south, fig. 1), which typically have streamflow greater than $1.0 \mathrm{ft}^{3} / \mathrm{s}$ (as measured during synoptic seepage surveys in 1982 and 1995-97). Other tributaries in the study area commonly have streamflow less than $1.0 \mathrm{ft}^{3} / \mathrm{s}$ or are dry. White Rock Creek, which is the only perennial tributary in the study area, has been dammed to create Lovewell Reservoir; this reservoir is used for storage of irrigation water, flood control, and recreation. Sportsmans Lake (fig. 1), which drains into Buffalo Creek, is regulated by the Kansas Department of Wildlife and Parks for waterfowl and recreational use. 


\section{Hydrologic System}

The hydrologic system of the study area includes both surface and ground water. Sources of water to the hydrologic system from outside the area are the Republican River itself, the Courtland Canal, and the movement of ground water across the study-area boundary (fig. 2). Within the study area, precipitation is the main source of water to the hydrologic system.

For example, precipitation may fall directly into water bodies; move by overland flow into tributaries, canals, or the Republican River; or infiltrate into the ground where it may be used by plants or percolate to the water table (fig. 2). Evaporation from water bodies and the land surface and evaporation and transpiration (evapotranspiration) by plants remove water from the hydrologic system within the study area. Surface water in the Republican River and ground water are also discharged from the hydrologic system at the downstream end of the study area (fig. 2). Water diverted within the study area by humans may be consumed and removed from the system, but some of the diverted water may be returned to the system by per- colation to the water table or through discharges into tributaries, canals, or the Republican River (fig. 2).

Within the study area, there can be movement of water between the ground- and surface-water parts of the hydrologic system. Most of this movement takes place along the Republican River; however, movement can also occur along tributaries and canals in the study area. Usually the Republican River is a gaining stream - that is, the ground water flows into the river from the adjacent aquifer because the water table is higher than the water level in the stream (fig. 2). At times this condition may be reversed, and the Republican River becomes a losing stream-that is, water flows from the river to the aquifer because the water table in the adjacent aquifer is lower than the water level in the river.

\section{Climate and Drought Effects}

Although the climate of the study area is subhumid (Kansas Water Resources Board, 1961, p. 27), precipitation and evaporation in the study area are quite variable, both from year to year and within any year. Precipitation and evaporation generally are

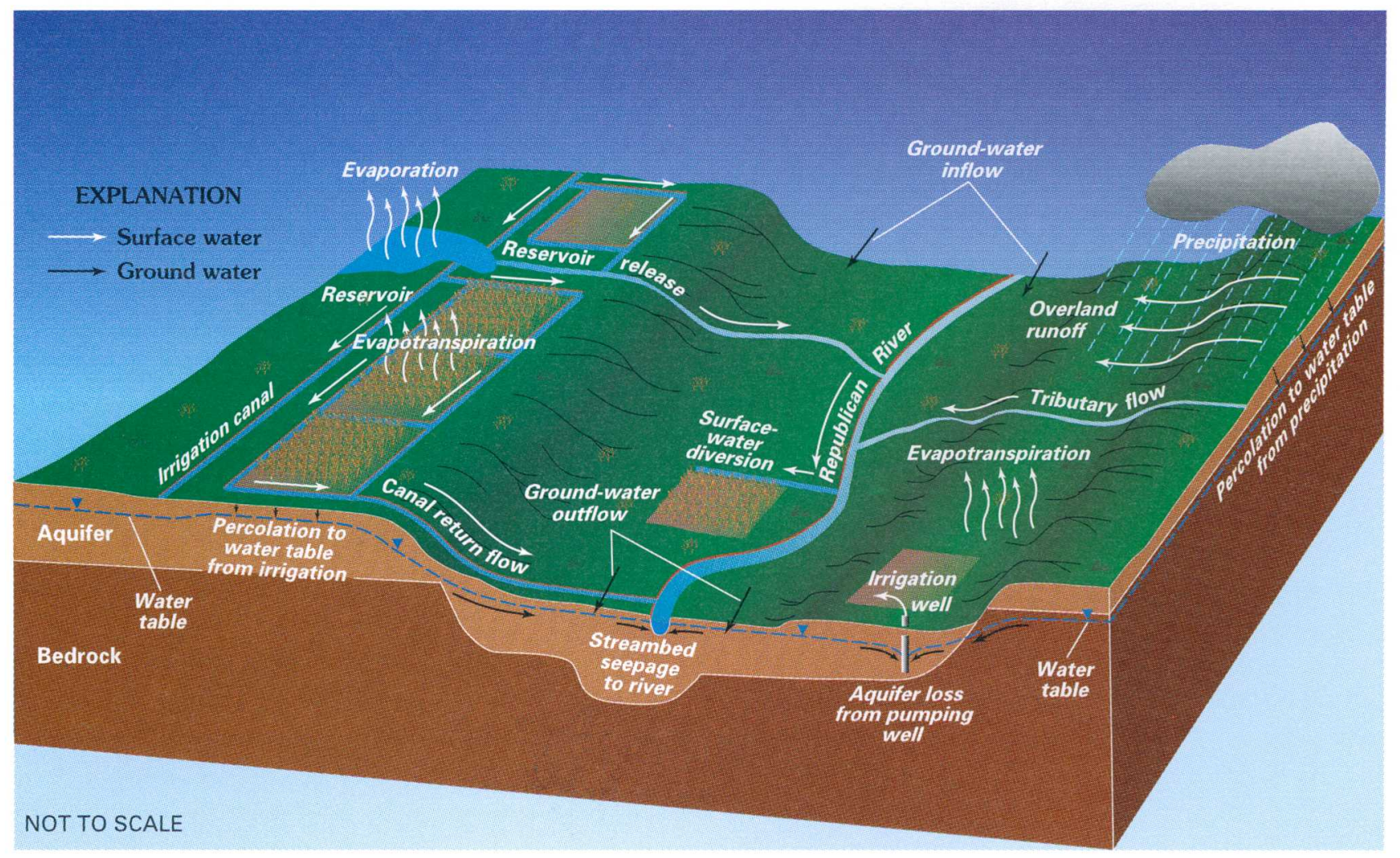

Figure 2. Conceptualized hydrologic system and components of flow in study area.

6 Effects of Water-Budget Components on Streamflow in the Republican River From Near Hardy, Nebraska, to Concordia, Kansas, October 1980-September 1995 
inversely related; during periods of abundant precipitation, evaporation typically is much smaller than during periods of little or no precipitation. Average annual precipitation (1951-80) ranges from 25 to $29 \mathrm{in} / \mathrm{yr}$ from west to east across the study area (Hedman and Engel, 1989). Average annual (1956-70) free watersurface evaporation ranges across the study area from about $48 \mathrm{in} / \mathrm{yr}$ in the east to about $52 \mathrm{in} / \mathrm{yr}$ in the west (Farnsworth and others, 1982). Recorded annual precipitation at the weather station at Concordia, Kansas, during water years 1933-96 ranged from 12.03 in. in 1956 to 50.86 in. in 1993 (fig. $3 A$ ). Average monthly precipitation of 0.65 in. for January, the driest month, was about one-seventh of the average of 4.37 in. for June, which was the wettest month, during water years 1933-96.

Recorded annual pan evaporation at Lovewell Reservoir, Kansas (fig. 1), during water years 1959-95 ranged from $33.55 \mathrm{in} / \mathrm{yr}$ in the extremely wet year of 1993 to $62.63 \mathrm{in} / \mathrm{yr}$ in 1959 (fig. $3 E$ ); however, evaporation typically was recorded only during the months of April through October in any year (National Oceanic and Atmospheric Administration, 1958-96). Generally, monthly average recorded pan evaporation at Lovewell Reservoir was greatest during July and August, when it averaged 13.75 and $13.65 \mathrm{in} / \mathrm{mo}$, respectively, and least in October, when it averaged $6.32 \mathrm{in} / \mathrm{mo}$; pan evaporation probably averaged much less during the months of November-March when it was not recorded and temperatures generally were colder than during the rest of the year.

The continental climate of Kansas is conducive to prolonged droughts and numerous floods. Droughts occur when precipitation is less than average for several consecutive years, whereas floods typically occur during periods of greatly increased rainfall over relatively short time periods of hours or days (Clement, 1991). During periods of drought, evaporation tends to be large and to amplify the effect of the drought. All or part of the five major regional droughts (1929-41, 1952-57, 1962-72, 1974-82, and 1988-92) and four of the five major floods $(1935,1951,1973$, and 1993 shown; 1903 not shown) that have occurred in the study area since 1900 (Clement, 1991; Dennis Lacock, U.S. Geological Survey, oral commun., 1997) are shown in figure $3 F$ and table 1 . Continuous precipitation data beginning in 1886 are available, but streamflow data before 1931 are not available for sites in or near the study area. Although average annual precipitation amounts at Belleville, Kansas, were similar dur- ing the three droughts shown in table 1, average annual streamflow in the Republican River at the nearby gaging station near Hardy, Nebraska, decreased after Harlan County Dam was completed in 1952. Completion of Harlan County Dam just as the drought of 1952-57 was beginning and the filling of the reservoir behind the dam may have exacerbated the reduction in streamflow during this drought.

Although average annual precipitation was greater during the drought of 1988-92 than during the drought of 1952-57 (table 1), average annual streamflow near Hardy, Nebraska, and at Concordia, Kansas, was less during the 1988-92 drought. The decrease in average annual streamflow may be due in part to diversion of water from the Republican River upstream from Hardy for use by KBID and other irrigators and to smaller releases from Harlan County Dam. Some of the decrease in streamflow near Hardy and at Concordia may be due in part to indirect causes. The use of ground water for irrigation may have resulted in the diversion of some water that otherwise would have become streamflow. In addition, farming practices designed to reduce the erosion of top soil, such as the construction of terraces and farm ponds, also may have reduced runoff into streams and contributed to the decrease in average annual streamflow. Average annual streamflow gains between the gaging stations near Hardy, Nebraska (site 1, fig. 1), and at Concordia, Kansas (site 21, fig. 1), during the 1988-92 drought were almost double the gains during the 1952-57 drought (table 1). The larger streamflow gains during the 1988-92 drought probably were caused by canal return flows from KBID, which did not begin full operation until 1958. At times during the 1952-57 and 1988-92 droughts, streamflow at Concordia, Kansas, was less than the MDS. Streamflow at Concordia during September through November 1991 was much less than the MDS than at any time during the drought of 1952-57 (compare figs. $4 A$ and $B$ ).

Comparison of streamflow with precipitation and the Palmer Modified Drought Severity Index (Heddinghouse and Sabol, 1991) (fig. 3) shows that generally the periods of higher and lower streamflow are similar to the wetter and drier periods of precipitation and of the drought index although the intensity may differ between streamflow and the drought index. The difference in intensity probably is due in part to the effect of regulation of the surface-water system in the study area by dams and reservoirs. For example, streamflow was much less during October 1990 
A. Precipitation at Concordia, Kansas

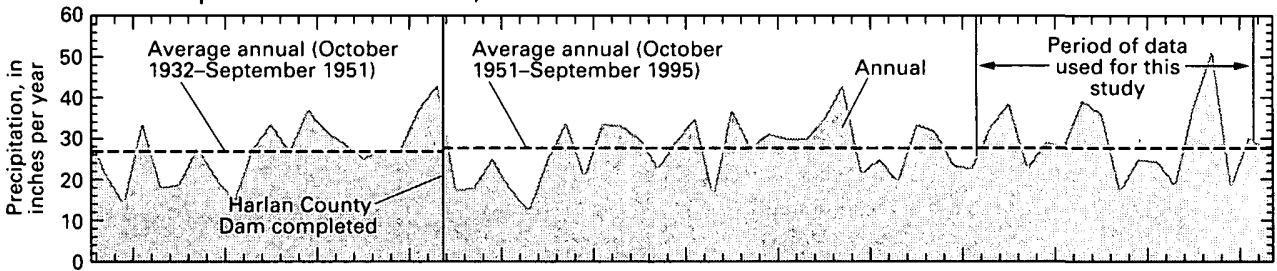

B. Gaged streamflow near Hardy, Nebraska (site 1, fig. 1)

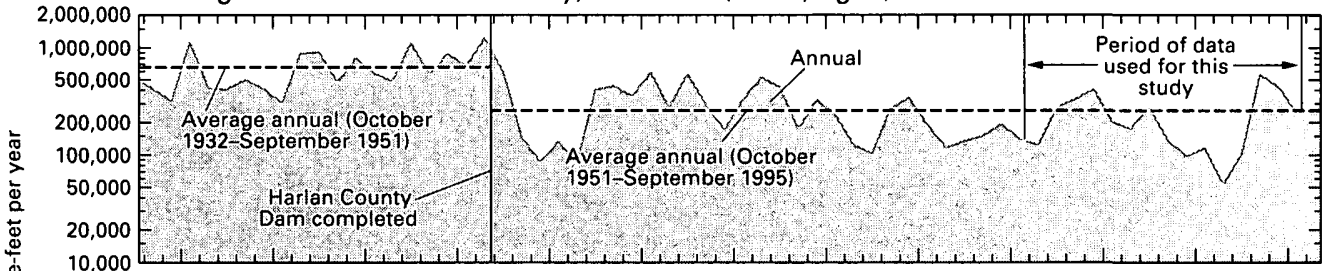

C. Gaged streamflow at Concordia, Kansas (site 21, fig. 1)

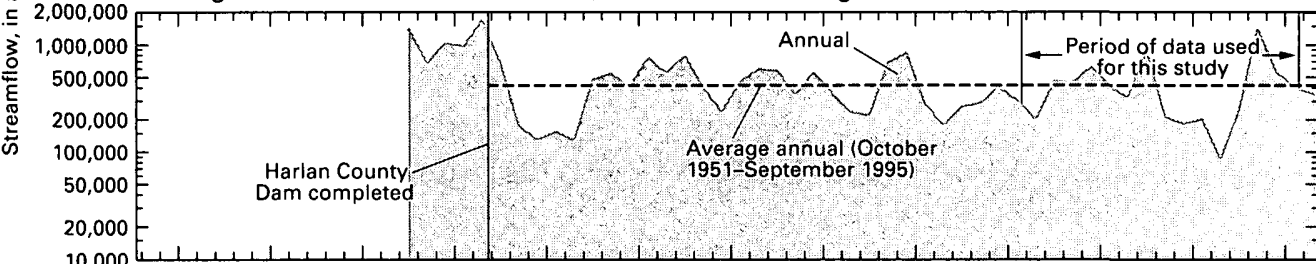

D. Streamflow gain in Republican River from near Hardy, Nebraska to Concordia, Kansas

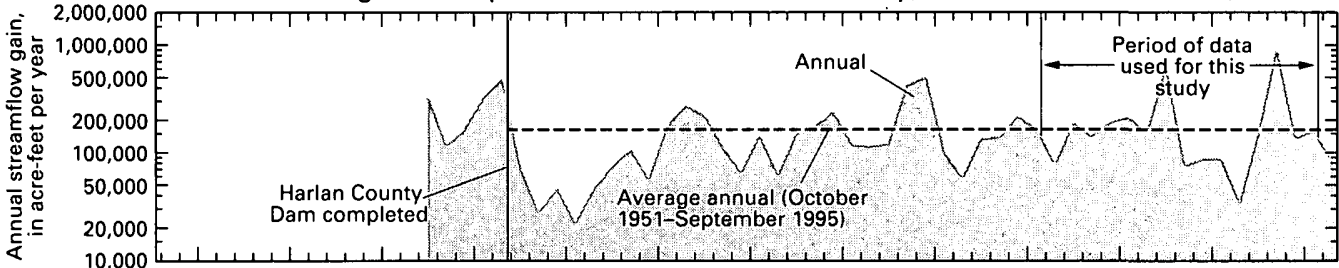

E. Free water-surface evaporation at Lovewell Reservoir, Kansas

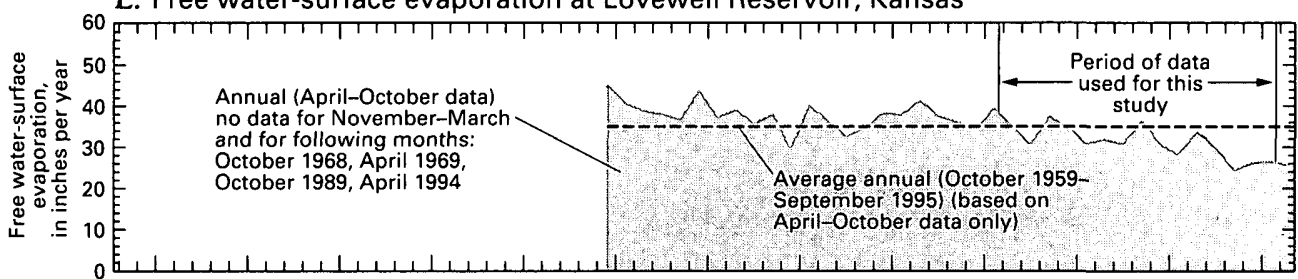

$F$. Drought indices, north-central Kansas-extreme drought, -4 or less; extreme wetness, 4 or more

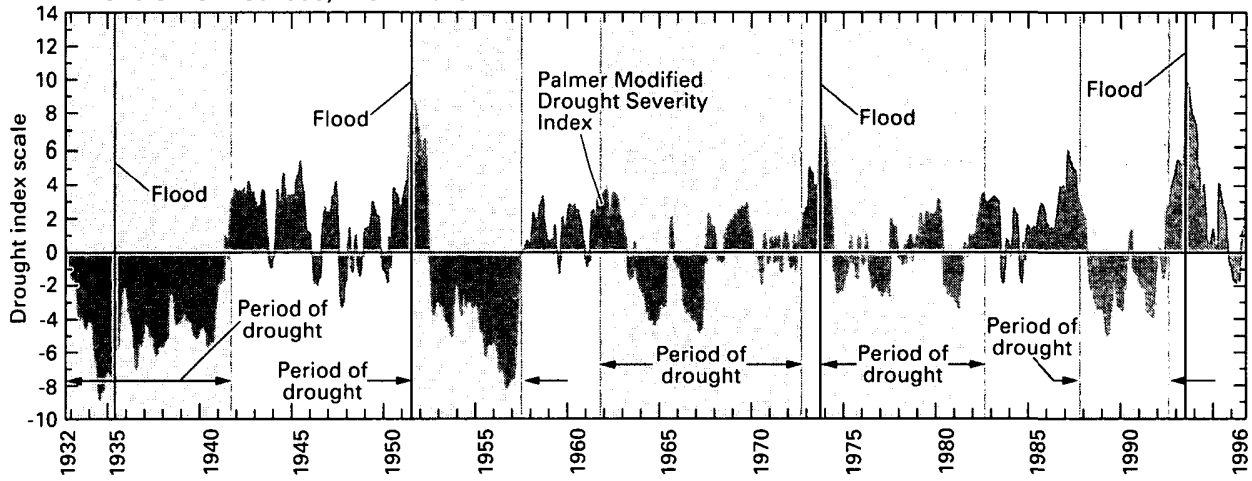

Figure 3. (A) Precipitation at Concordia, Kansas; (B) gaged streamflow of Republican River near Hardy, Nebraska; (C) gaged streamflow at Concordia, Kansas; $(D)$ streamflow gain in Republican River from near Hardy, Nebraska, to Concordia, Kansas; $(E)$ evaporation at Lovewell Reservoir, Kansas; and $(F)$ periods of significant droughts and floods in north-central Kansas, October 1932-September 1996 (sources: $A$ and $F$, precipitation and drought indices from National Climatic Data Center, Asheville, North Carolina; $B, C$, and $D$, streamflow data from U.S. Geological Survey, Lawrence, Kansas; $E$, evaporation data from National Oceanic and Atmospheric Administration, 1958-96; and $F$, droughts and floods before 1990 from Clement, 1991).

8 Effects of Water-Budget Components on Streamflow in the Republican River From Near Hardy, Nebraska, to Concordia, Kansas, October 1980-September 1995 
Table 1. Comparison of average annual precipitation, streamflow, and canal return flow in the Republican River in the study area and average annual surface-water diversions and reservoir releases upstream from the study area during six selected reference periods

[All values except precipitation are average annual values in acre-feet per water year; precipitation is average annual in inches per water year; --, no data; shading indicates drought periods. Precipitation data from National Climatic Data Center, Asheville, North Carolina; streamflow data from U.S. Geological Survey, Lawrence, Kansas; canal return flow data from Kansas Bostwick Irrigation District, Courtland, Kansas, and Bureau of Reclamation, McCook, Nebraska; surface-water diversion data from Bureau of Reclamation, McCook, Nebraska; and reservoir release data from Bureau of Reclamation, McCook, Nebraska, and U.S. Geological Survey, Lincoln, Nebraska]

\begin{tabular}{|c|c|c|c|c|c|c|}
\hline \multirow{2}{*}{$\begin{array}{c}\text { Environmental factors } \\
\text { and locations }\end{array}$} & \multicolumn{6}{|c|}{ Selected reference periods (water years) } \\
\hline & $1933^{-41}$ & $1942-51$ & $1952-57$ & $1958-87$ & $1988-92$ & $1993-95$ \\
\hline Precipitation & (u) & & $+u$ & & & \\
\hline Belleville, Kansas & 2485 & 32.74 & tent 23.12 & 31.87 & 2415 & 36.97 \\
\hline Concordia, Kansas & 21.50 & 31.47 & 18.89 & 29.42 & & 32.76 \\
\hline Streamflow & & & & & & \\
\hline Near Hardy, Nebraska & 531,699 & 763,296 & 238,863 & 273,253 & 100,662 & 407,018 \\
\hline Concordia, Kansas & 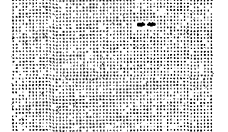 & -- & 285,488, & 450,416 &  & 790,029 \\
\hline $\begin{array}{l}\text { From near Hardy, Nebraska, to Con- } \\
\text { cordia, Kansas } \\
\text { Reservoir releases }\end{array}$ & . & -- & 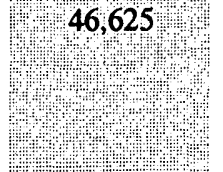 & 177,163 & $\begin{array}{l}83,662+1 \\
+2,\end{array}$ & 383,011 \\
\hline $\begin{array}{l}\text { Harlan County Dam } \\
\text { Surface-water diversions }\end{array}$ & 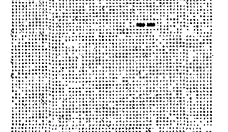 & -- & 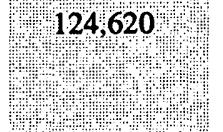 & 223,316 & $\begin{array}{l}989 \text { मीय } \\
\text { मीय }\end{array}$ & 183,308 \\
\hline $\begin{array}{l}\text { Upstream from Hardy, Nebraska, } \\
\text { for Bostwick Irrigation Districts }\end{array}$ & (4) & -- & 43,416 & 113,990 & मा16,841? & 50,501 \\
\hline Canal return flow & in & & He & & गियाय & \\
\hline Downstream from Hardy, Nebraska & m & -- & $14+4-4$ & 6,912 & 6,061 & 6,006 \\
\hline
\end{tabular}

\footnotetext{
${ }^{1}$ The Bostwick Irrigation District in Nebraska and the Kansas Bostwick Irrigation District are authorized to divert water from the
} Republican River in Nebraska for irrigation.

through May 1992 than during September 1988 through September 1989 (fig. 4B) although the drought index and graphs of precipitation show that September 1988 through September 1989 actually was a more intense drought period than was October 1990 through May 1992 (compare figs. 3 and 4B). Streamflows during the drought of September 1988 through September 1989 were supplemented by larger releases from Harlan County Dam, and demands for surface water may have been less in part because of reserves of stored water in the soil and ground from the preceding above-normal precipitation period (fig. $3 A$ and $4 B$ ). During the September 1988 through September 1989 drought and the 2 years of below-normal precipitation following it (fig. 4B), water stored in the soil, ground, and especially reservoirs probably was not replenished, and all reserves most likely were essentially depleted, leaving little or no stored water available to moderate the effect of the drought on streamflow during October 1990 through May 1992.

\section{WATER-BUDGET COMPONENTS OF STREAMFLOW}

A mass-balance model is based on the concept that the input to a system should equal the output from the system if change in storage is zero. A water budget can be used to quantify the input to and output from a hydrologic system. The mass-balance water budget used in this study describes flow in the Republican River only and not the hydrologic system of the entire 
A. October 1951-September 1957
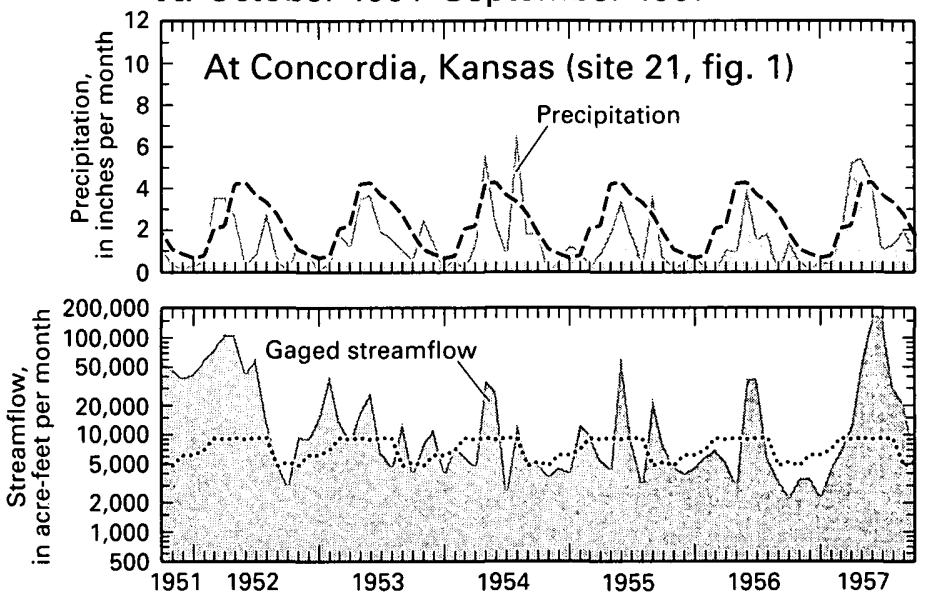

EXPLANATION
B. October 1987-September 1992
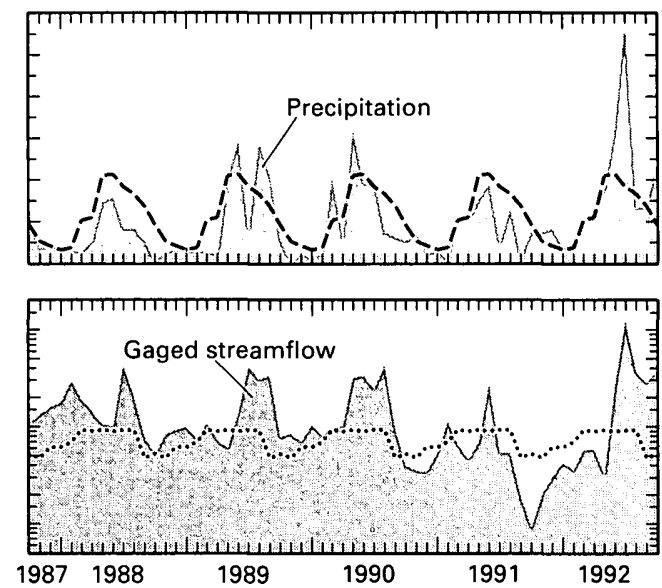

--- Monthly average precipitation (October 1951-September 1992)
......... Monthly minimum desirable streamflow

Figure 4. Monthly precipitation and gaged streamflow at Concordia, Kansas, (A) October 1951-September 1957 and (B) October 1987-September 1992 (sources: precipitation data from National Climatic Data Center, Asheville, North Carolina; streamflow data from U.S. Geological Survey, Lawrence, Kansas).

study area. Therefore, not all components that contributed water to or removed water from the study area (fig. 2) were considered part of the water budget describing flow in the Republican River. Water that enters or leaves the Republican River in the study area through tributaries or canals, through exchange of water between the aquifer and the river by streambed seepage, through evaporation from the Republican River, or through use by humans were considered to be major components of flow to the Republican River and were included in the water budget.

Other components of flow were considered minor and were not included in the water budget because they are included within the major components or are small in comparison. For example, most of the precipitation that falls within the study area becomes part of other components (for example, flow in tributaries) before it reaches the Republican River and, therefore, is accounted for in the contributions made by the major components; the remaining precipitation that falls directly on the Republican River is small and not considered. No municipal or industrial discharges were included in the water budget because all the cities and industries in the study area evaporated or recycled their used water or discharged it outside the study area or upstream from a gaging station on a tributary (included in tributary flow).
The water budget and major components used to describe flow in the Republican River in the study area are upstream flow (UF) near Hardy, Nebraska, plus tributary flow (TF), plus streambed seepage (SS), minus evaporation $(E)$, plus reservoir releases $(R R)$, plus canal return flow (CRF), minus surface-water diversions (SWD), equals water-budget estimate (WBE) of downstream flow (DF), or:

$$
\mathrm{UF}+\mathrm{TF}+\mathrm{SS}-\mathrm{E}+\mathrm{RR}+\mathrm{CRF}-\mathrm{SWD}=\mathrm{WBE} \text { of } \mathrm{DF}
$$

The components of the mass-balance water budget typically can be grouped into components that are less affected by human activity within the study area, including upstream flow, tributary flow, streambed seepage, and evaporation, and components that are more affected by human activity within the study area, including reservoir releases, canal return flow, and surface-water diversions. Components that are more affected by human activity can typically be modified more easily during drought periods to increase streamflow than components less affected by human activity.

Each of the components of flow used in the water budget were quantified on a monthly basis for the period October 1980 through September 1995 (hereinafter referred to as water years 1981-95). The monthly interval was chosen as a compromise among the varying intervals (daily to annual) of the available data to best describe the interaction of the various compo- 
nents in the water budget. These quantified components then were combined to make monthly estimates of flow in the Republican River at Concordia, Kansas, during water years 1981-95 and the estimates were compared with measured streamflow at Concordia.

A variety of sources of measured or reported data were used for the monthly estimates of each major component of the water budget. All the major components of flow were converted, if necessary, from the units in which they were originally reported into acrefeet per month. The methods used to estimate each component and the data used to make these estimates are described in the sections that follow. The monthly estimates of the major components of flow for water years 1981-95 are included in table 5 in the "Supplemental Information" section at the end of this report.

\section{Upstream Flow}

Upstream flow data were collected by USGS at a streamflow-gaging station near Hardy, Nebraska (site 1, fig. 1). These data represented measured inflow for purposes of the water budget. Gaged average daily streamflow data stored in the USGS's National Water Information System (NWIS) were summed by month. Comparison of hydrographs of streamflow near Hardy, Nebraska, and at Concordia, Kansas, show water in the Republican River takes about 1 day to travel from the gaging station near Hardy (site 1, fig. 1) to the gaging station at Concordia (site 21 , fig. 1); therefore, the upstream flow used was for the day previous to that measured at Concordia.

\section{Tributary Flow}

Tributary flow includes streamflow measured by the USGS at gaging stations on White Rock Creek at Lovewell, Kansas (site 6, fig. 1), and on Buffalo Creek near Jamestown, Kansas (site 17, fig. 1); approximately 30 and 28 percent of the study area are upstream from these gaging stations, respectively. Tributary flow in ungaged parts of the study area or during periods of missing streamflow measurements at the gaging stations was estimated as described in the following paragraphs.

The streamflow for the ungaged part of the study area was computed by multiplying the average of the monthly streamflow for the unregulated, gaged part of the study area-as measured or estimated at the gaging stations on White Rock Creek near Burr Oak (site 4, fig. 1) and on Buffalo Creek near Jamestown (site 17, fig. 1)-by the ratio of the ungaged part of the study area to the unregulated, gaged part of the study area. During most of water years 1981-95, about 42 percent of the study area was ungaged, and about 48 percent of the study area was unregulated and upstream from the gaging stations on White Rock Creek near Burr Oak and on Buffalo Creek near Jamestown; the remaining approximately 10 percent of the study area was in the gaged and regulated part of the White Rock Creek drainage between the gages near Burr Oak and at Lovewell, Kansas (sites 4 and 6, fig. 1). Following June 1990, when the streamflow gage on Buffalo Creek near Jamestown was discontinued, the ungaged part of the study area increased to about 70 percent and the unregulated, gaged part of the study area decreased to about 20 percent.

Streamflow for Buffalo Creek during that part of water years 1981-95 when it was ungaged near Jamestown (July 1990 through September 1995) was estimated using stepwise multiple linear regression analysis (Statware, Inc., 1990) of monthly runoff data during July 1959 through June 1990 from the gage on Buffalo Creek near Jamestown with that from several of the closest streamflow-gaging stations on unregulated streams. The nearby streamflow gages used in the stepwise multiple linear regression were White Rock Creek near Burr Oak, Kansas (site 4, fig. 1); Salt Creek near Ada, Kansas (index map, fig. 1); and Little Blue River near Barnes, Kansas (index map, fig. 1). The correlation coefficient ( $r$ ) of this stepwise multiple linear regression was 0.86 . The equation that resulted from the stepwise multiple linear regression was used to estimate streamflow at the gaging station on Buffalo Creek near Jamestown during the ungaged period (1990-95). To test how well estimated streamflow for Buffalo Creek compared to measured flows, this same equation then was used to estimate streamflow for Buffalo Creek during the period when the gage was operating (1959-90). The strong correlation (r equals 0.82 ) of the measured and estimated streamflows at the gage on Buffalo Creek near Jamestown during the gaged period is shown in figure 5 .

Because White Rock Creek is regulated upstream from the gaging station at Lovewell, an attempt was made to separate the measured discharge into that which could be considered as released from Lovewell Reservoir and that which could be considered unregulated streamflow. The unregulated streamflow was 


\section{EXPLANATION}

\section{1:1 line}

Measured and estimated stream flow in Buffalo Creek nea Jamestown, Kansas (site 17, fig. 1). Estimated streamflow determined using equation resulting from stepwise regression of monthly runoff data for this gaging station with that for gaging stations at White Rock Creek near Burr Oak, Kansas (site 4, fig. 1), Salt Creek near Ada Kansas (index map, fig. 1), and Little Blue River near

Barnes, Kansas (index map,

fig. 1). Correlation coefficient (r) is $\mathbf{0 . 8 2}$ for comparison of measured and estimated streamflow

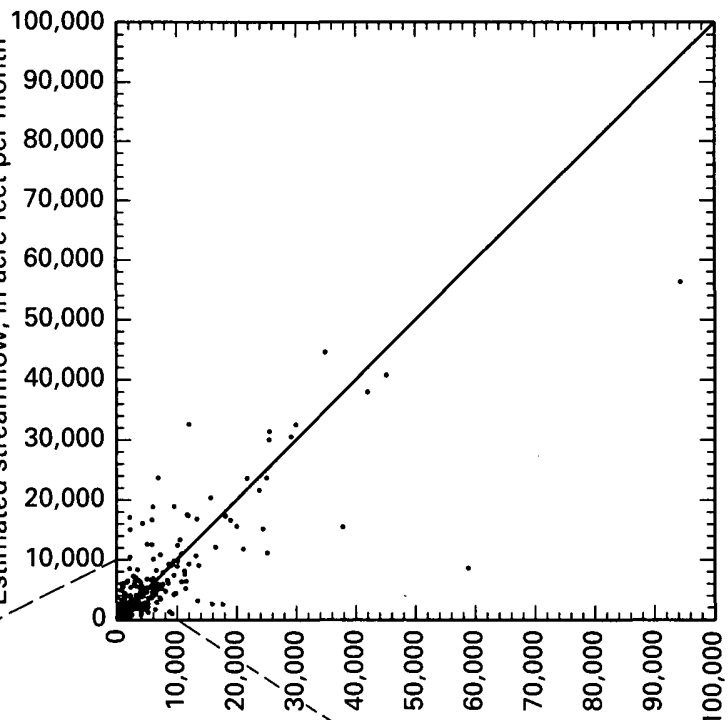

Measured streamflow, in acre-feet per month

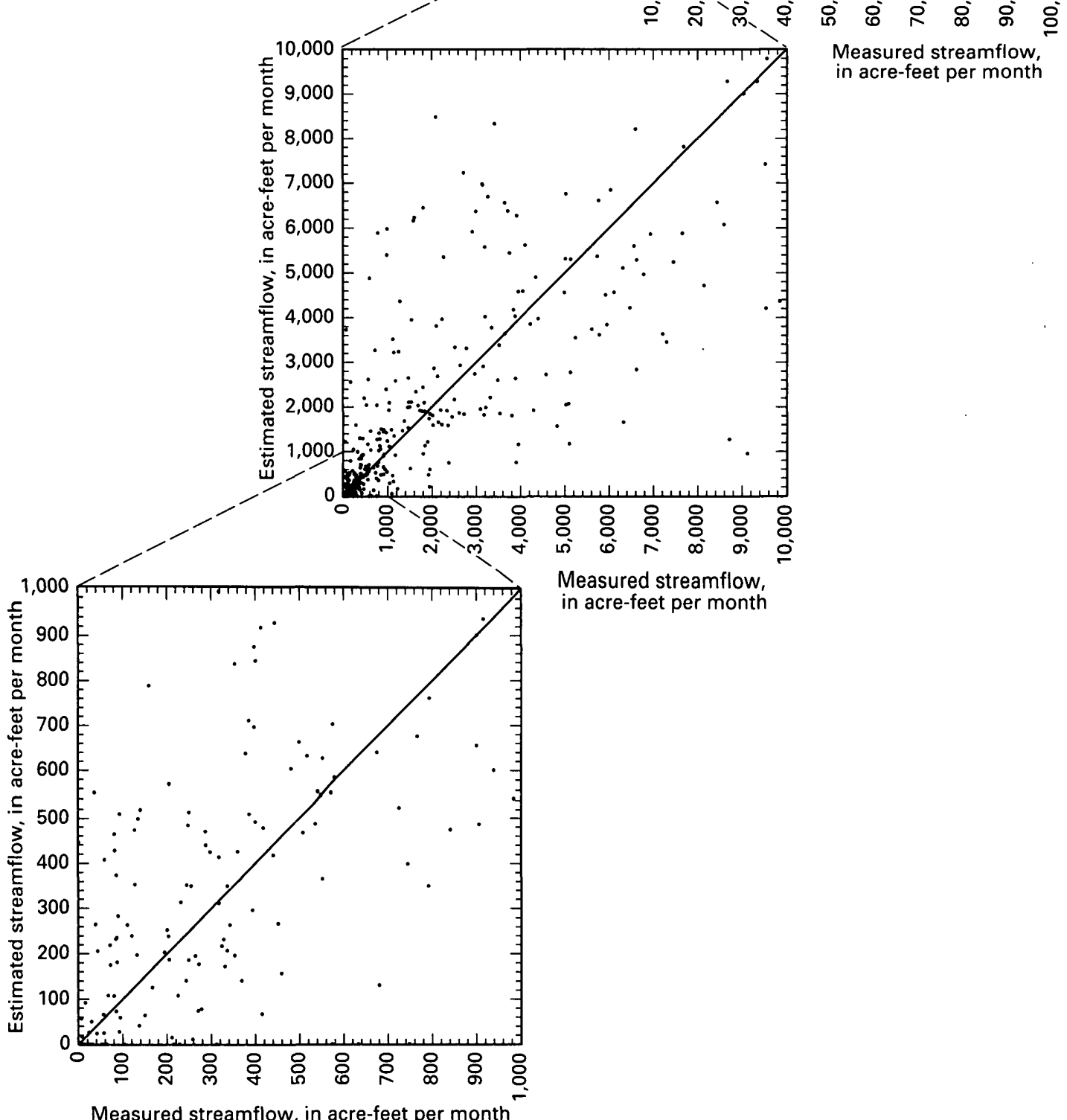

Figure 5. Comparison of measured and estimated streamflow at gaging station on Buffalo Creek near Jamestown, Kansas, July 1959-June 1990 (source of data: U.S. Geological Survey, Lawrence, Kansas). 
estimated as that part of the average daily discharge that was less than or equal to $10 \mathrm{ft}^{3} / \mathrm{s}$ because the gage is only about $1,400 \mathrm{ft}$ downstream from the Lovewell Reservoir dam with no intervening tributaries and because measured flows greater than $10 \mathrm{ft}^{3} / \mathrm{s}$ increase abruptly to (or decline abruptly from) about 100 to $1,000 \mathrm{ft}^{3} / \mathrm{s}$ and may not correspond with periods of precipitation, indicating they are reservoir releases. This estimated, unregulated streamflow was included in the tributary flow component of the water budget. Measured average daily discharge greater than $10 \mathrm{ft}^{3} / \mathrm{s}$ was included in the reservoir release component.

\section{Streambed Seepage}

Streambed seepage is defined in this study as the increase or decrease of flow in the Republican River as a result of seepage between the aquifer and the river. Streambed seepage is typically one of the most difficult water-budget components to accurately quantify. It can be estimated by conducting synoptic seepage surveys or by using hydrograph-separation techniques. Seepage surveys are more accurate but are only practical at lower flows where the difference between the measured inflows and outflows is greater than the potential error of the measurements.

For this water-budget estimate, a relation between seepage-survey data and average daily flow at Concordia, Kansas, was used to compute daily streambed seepage for flow from 150 through $500 \mathrm{ft}^{3} / \mathrm{s}$ at Concordia because seepage data were available for this range in flow, and a hydrograph-separation technique was used for flows less than $150 \mathrm{ft}^{3} / \mathrm{s}$ or greater than $500 \mathrm{ft}^{3} / \mathrm{s}$. Daily seepage flows were summed to get the monthly streambed seepage flows shown in table 5 in the "Supplemental Information" section at the end of this report. Mean daily streamflow at Concordia, Kansas, was less than $150 \mathrm{ft}^{3} / \mathrm{s}$ or exceeded $500 \mathrm{ft}^{3} / \mathrm{s}$ about 45 percent of the time during water years 1981-95.

\section{Synoptic Seepage Surveys}

During this study, USGS personnel made discharge measurements during eight synoptic seepage surveys along the Republican River from near Hardy, Nebraska, to Concordia, Kansas, and on all major tributaries (fig. 1), mostly during relatively low-flow periods. Standard USGS discharge techniques were used (Carter and Davidian, 1977; Buchanan and Somers, 1984). Table 2 is a compilation of the results of these measurements. Two seepage surveys conducted during 1982 and documented in Spruill (1985) also are noted in table 2. Figure 6 is a graphical representation of the dáta from the Republican River synoptic seepage-survey sites listed in table 2. Measurements were not made during the summer irrigation period because of few opportunities with sufficiently low flows during the summer of 1996. Streambed seepage was estimated from the synoptic seepage-survey data as the change in streamflow between near Hardy, Nebraska, and Concordia, Kansas, after subtracting measured tributary flow. Some of the streambed seepage estimates are somewhat overestimated because the smaller tributaries were not measured during all synoptic surveys.

Table 2 and figure 6 confirm that the Republican River between Hardy and Concordia is predominately a gaining stream; that is, streambed seepage is positive, and flow is from ground water to the river. Streambed seepage in this reach for the 10 measurement dates ranged from 17.2 to $126.1 \mathrm{ft}^{3} / \mathrm{s}$ with a median value of $32.6 \mathrm{ft}^{3} / \mathrm{s}$. These values were always greater than the uncertainty associated with the streamflow measurements. Some variability in streambed seepage occurred between measurement dates and between survey sites. Streambed seepage tends to increase with increasing streamflow as demonstrated by the strong correlation between streambed seepage and discharge at Concordia (fig. 7). The seasonal differences in these data are likely a result of the winter measurements being conducted at higher flows (table 2 ).

The results of a linear regression of seepage measurements with streamflow at Concordia, Kansas (fig. 7), was used to estimate daily streambed seepage for streamflows at Concordia ranging from 150 through $500 \mathrm{ft}^{3} / \mathrm{s}$. Streamflow at Concordia between 150 and $500 \mathrm{ft}^{3} / \mathrm{s}$ was used because 9 of the 10 sets of seepage measurements that best agree with the linear regression line (fig. 7) occurred when corresponding streamflow at Concordia was within this range. For much greater streamflows, this relation was not considered reliable because of a lack of seepage measurements and because it produced seepage estimates that in many cases far exceeded the hydrograph-separation technique results. Seepage measurements are rarely made during higher flows because the potential errors involved in measuring the larger flows typically are as large or larger than the amount of streambed seepage. 


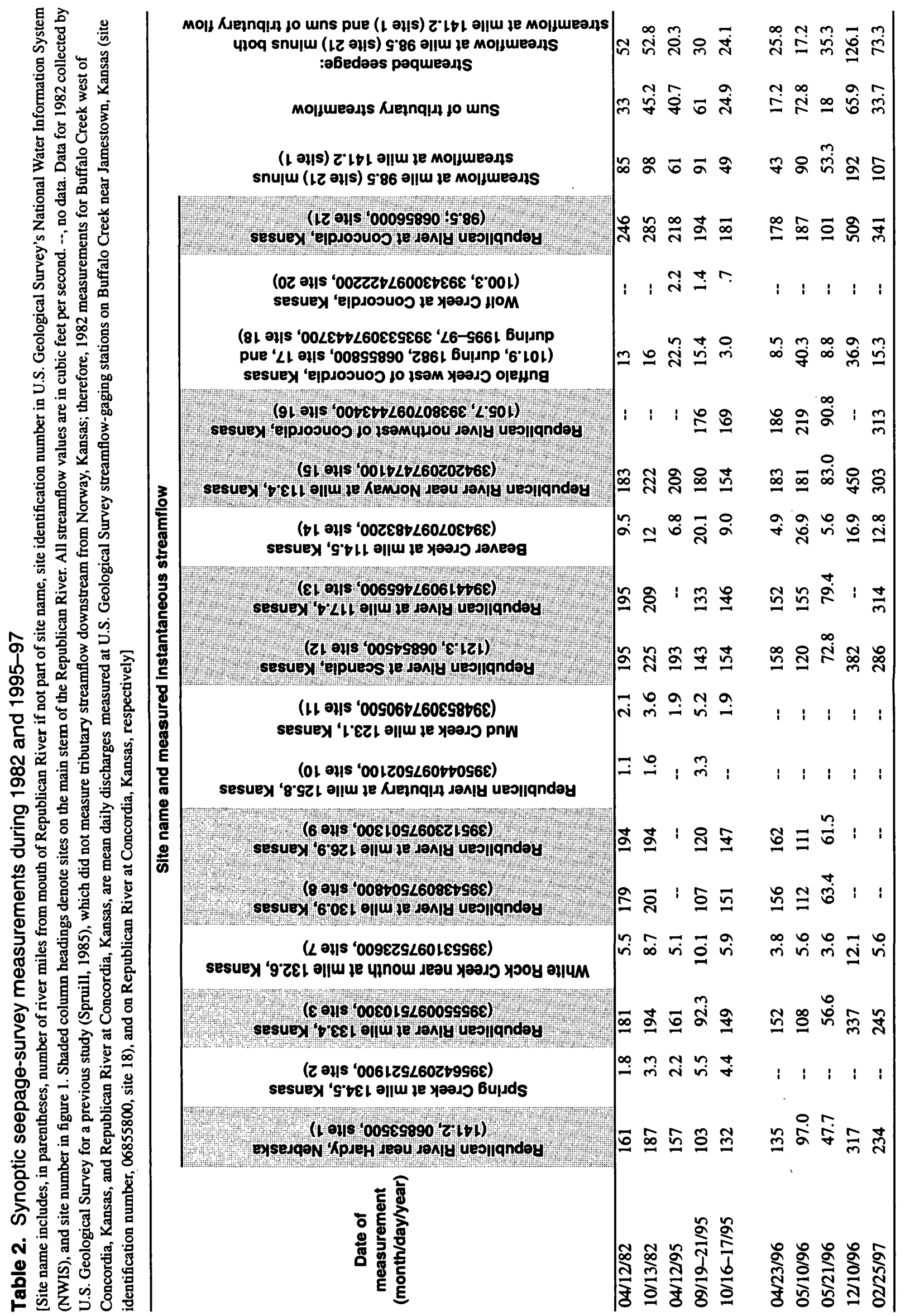

14 Effects of Water-Budget Components on Streamflow in the Republican River From Near Hardy, Nebraska, to Concordla, Kansas, October 1980-September 1995 









Figure 7. Comparison of measured streamflow at Concordia, Kansas, during 1982 and 1995-97 with streambed seepage estimated from synoptic seepage-survey data (sources: Spruill, 1985; U.S. Geological Survey, Lawrence, Kansas).

\section{Hydrograph Separation}

For streamflows in the Republican River at Concordia less than $150 \mathrm{ft}^{3} / \mathrm{s}$ or exceeding $500 \mathrm{ft}^{3} / \mathrm{s}$, streambed seepage was estimated using the computer program BFI4 (Wahl and Wahl, 1995) that computes daily streambed seepage from average daily streamflow. The BFI4 program uses streamflow hydrographseparation techniques to estimate that part of flow in an unregulated stream that is from streambed seepage; these techniques are based on a set of base-flow separation procedures proposed by the Institute of Hydrology $(1980 \mathrm{a}, \mathrm{b})$. The average daily streamflow data collected by the USGS at gaging stations near Hardy, Nebraska (site 1, fig. 1), and at Concordia, Kansas (site 21, fig. 1), were used as input to the program. The BFI4 program also requires specification of the streamflow minimum-increment test interval $(\mathrm{N})$ in days and the turning-point test factor (f). A value of $\mathrm{N}$ equal to 7 days was used in this study because the BFI4 estimates of streambed seepage were typically more consistent and tended to reduce the probable overestimation of streambed seepage by the BFI4 program discussed later in this report. A value of $f$ equal to 0.90 was used in this study because it was proposed for use by the Institute of Hydrology (Wahl and Wahl, 1995). To become a turning point used to estimate the base flow (streambed seepage), the minimum streamflow in an increment test interval multiplied by the value of $f$ must be less than the minimums in both adjacent increment test intervals. An example and detailed discussion of these techniques can be found in Wahl and Wahl (1995).

The Republican River is regulated by Harlan County Dam; however, during most periods the Republican River can be viewed as an unregulated stream because, except during higher flows, either no water is released from Harlan County Lake (about 68 percent of the time during water years 1981-95) or all streamflow and releases from the lake are fully diverted upstream from Guide Rock, Nebraska (about 23 percent of the time during water years 1981-95), for irrigation. About 75 percent of the time during water years 1981-95, the Republican River at Hardy was not affected by releases or diversions; thus, use of hydrograph-separation techniques was similar to their use in estimating streamflow seepage for an unregulated stream.

Contributions to streamflow from regulated sources that occur for periods longer than the minimum increment test interval (7 days) are considered part of the streamflow from which streambed seepage is estimated by the BFI4 program and may cause streambed seepage to be overestimated. Before the BFI4 program was used, the streamflow data from the 
gaging station at Concordia, Kansas, were modified to remove some of the effects of releases by Lovewell Reservoir. No adjustments were made for tributary flow or canal return flow, and as a result, the streambed-seepage component is an overestimate; adjustments were impractical due to insufficient tributary flow and canal return flow data. The net streambed seepage for the Republican River in the study area was then estimated as the BFI4 results for the gaging station near Hardy, Nebraska, subtracted from the BFI4 results for the gaging station at Concordia, Kansas, after compensating for a 1-day traveltime between the two stations. The results from the BFI4 program tended to overestimate streambed seepage when compared to same-day seepage-survey measurements (fig. 8).

\section{Evaporation}

Evaporation from the Republican River was estimated using monthly pan evaporation measured at Lovewell Reservoir, Kansas, and published by the

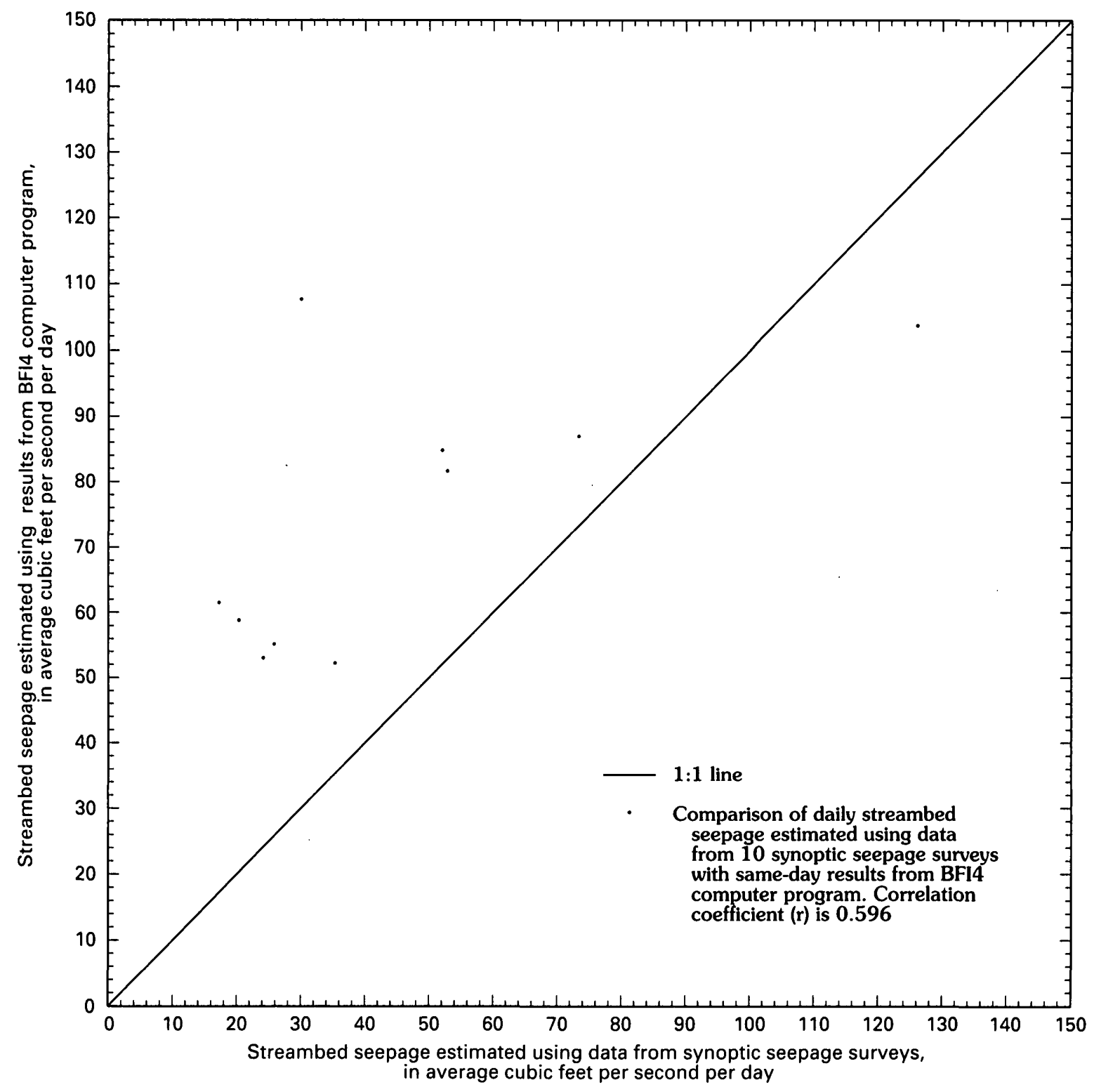

Figure 8. Comparison of streambed seepage estimated using data from 10 synoptic seepage surveys during 1982 and 1995-97 with streambed seepage estimated using BFI4 computer program (Wahl and Wahl, 1995) (sources: Spruill, 1985, and U.S. Geological Survey, Lawrence, Kansas). 
National Oceanic and Atmospheric Administration (1958-96). The free water-surface evaporation in the study area can be estimated by multiplying the pan evaporation at Lovewell Reservoir by the pan coefficient of 0.72 (Farnsworth and others, 1982). The amount of evaporation from the Republican River was estimated as the free water-surface evaporation for the month multiplied by the area of the upper surface of the river. The upper surface of the Republican River in the study area was estimated as $42.7 \mathrm{mi}$ long and $150 \mathrm{ft}$ wide. No evaporation was considered to have occurred during those months (typically November through March) without published values for pan evaporation at Lovewell Reservoir.

\section{Reservoir Releases}

Reservoir releases were estimated conservatively, as previously described in the "Tributary Flow" section, as that part of the average daily discharge greater than $10 \mathrm{ft}^{3} / \mathrm{s}$ measured at the USGS streamflow-gaging station on White Rock Creek at Lovewell, Kansas, which is just downstream from Lovewell Reservoir (fig. 1). That part of the average daily discharge less than or equal to $10 \mathrm{ft}^{3} / \mathrm{s}$ was considered to be unregulated streamflow and was included in the tributary flow component. Diversions from Lovewell Reservoir into the part of the Courtland Canal downstream from Lovewell Reservoir are not included in the gaged discharge because the canal's diversion point is upstream from the gaging station. As a result, most of the estimated reservoir releases occur only during or following periods of abundant precipitation or in anticipation of increased runoff the following spring.

\section{Canal Return Flow}

Canal return flow data were collected by KBID at discharge gates in calibrated manmade channels at the ends of the large canals and of the smaller canals (lateral lines) that divert water from them within the district. Canal return flow from KBID to the Republican River generally occurs only during the months that irrigation is allowed in the district (June through September). Although irrigation does not occur during all 4 months during all years, canal return flow has occurred in July and August every year since 1958.

The discharge of water from KBID canals to the Republican River was based on monthly data provided by KBID. Water discharged from the Courtland Canal directly into Lovewell Reservoir was not included in the canal return flow component, even though it is recorded as return flow by KBID. This is because, as discussed in the "Background" section, the Courtland Canal is used to transfer water from the Republican River upstream from the study area into Lovewell Reservoir for use by KBID. Only 90 percent of the discharge from the lateral lines upstream from Lovewell Reservoir were included in the canal return flow because approximately 10 percent of the KBIDirrigated land upstream from the reservoir is outside the study area. Downstream from Lovewell Reservoir, discharges from both lateral lines and canals were included in canal return flow.

\section{Surface-Water Diversions}

Surface-water diversions, the amount of surface water removed (diverted) by humans, were estimated from annual water-use reports completed and returned to DWR by users. The only uses for which surface water was diverted in the study area were irrigation and recreation; all diversions for municipal and industrial uses in the study area are from ground water. Many of the surface-water diversions (including the large diversions to and from Lovewell Reservoir for $\mathrm{KBID}$ and the diversions for recreation) were upstream from the gaging stations on White Rock Creek at Lovewell or on Buffalo Creek near Jamestown; these diversions already are accounted for in the tributary or canal return flow components. Only surface-water diversions from tributaries in the ungaged part of the study area or directly from the Republican River in the study area were considered to be part of this component. All water from these surface-water diversions was used for irrigation. The annual surface-water irrigation-use data for these diversions were divided into monthly data in the same monthly-to-annual ratios as the data for irrigation deliveries available from KBID.

\section{EFFECTS OF WATER-BUDGET COMPONENTS}

Comparison of the water-budget estimates during various flow conditions was needed to evaluate the importance of each component and how well the water-budget estimates matched downstream flow 
during these conditions. Smaller periods within water years 1981-95 were classified on the basis of streamflow conditions. The effects of the water-budget components on flow during drought conditions, when water demand may exceed water supply in the study area (as occurred during 1991 and 1992), were of special interest.

\section{Streamflow-Class Periods}

The streamflow-class designations were determined by computing monthly discharges using streamflow data from USGS streamflow-gaging stations near Hardy, Nebraska, and at Concordia, Kansas. The period of October 1951 through September 1995 was chosen to include a long enough period to be statistically valid while also avoiding inclusion of streamflow from the unregulated period before the completion of Harlan County Dam when the streamflow regime was different (fig. 3B). The 10-, 25-, 75-, and 90-percent streamflow exceedances during October 1951 through September 1995 were computed for each of the 12 calendar months. The four streamflow classes designated using these percent exceedances were 0-25 percent, high flow; $25-75$ percent, normal flow; 75-90 percent, low flow; and greater than 90 percent, extreme low flow. Each month during water years 1981-95 was assigned to one of the four streamflow classes by comparing the streamflow for the month with the exceedances computed for the corresponding calendar month. Adjacent months with the same streamflow class were grouped into streamflowclass periods. Some streamflow-class periods contain short periods when the flow met the criteria of other streamflow classes; however, these short periods were not considered long enough (less than 6 months) to be designated as separate periods.

During water years 1981-95, there were two highflow streamflow-class periods (September 1983 through June 1984 and February 1993 through March 1994), two periods in the low-flow class (October 1980 through June 1981 and September 1988 through June 1989), and one period in the extreme low-flow class (October 1990 through May 1992); the rest of water years 1981-95 included five periods in the normal-flow class (July 1981 through August 1983, July 1984 through August 1988, July 1989 through September 1990, June 1992 through January 1993, and April 1994 through September 1995). One example from each of the periods in the high-flow (February 1993-March 1994), normal-flow (July 1984-July 1986), low-flow (October 1980-June 1981), and extreme low-flow (October 1990-May 1992) classes were selected (fig. 9) and are discussed in this report with respect to the major components of the water budget. The average monthly value of each major component and downstream flow during the example streamflow-class periods and the percentage of the water-budget estimate these components represent are shown in table 3.

The example high-flow period (fig. 9) of February 1993 through March 1994 was chosen because it includes the flood of July 18-29, 1993, and generally had greater streamflows than the other high-flow period. These greater streamflows provide a better test of the usage of the water budget to estimate downstream flow for periods of high flow. The month of July 1993 was further selected as the period of highest flow. The example 2-year normal-flow period (fig. 9) of July 1984 through July 1986 was separated out of an approximately 4-year normal-flow period to be more similar in length to the other flow periods. The example normal-flow period includes short $(6$ months or less) high- and low-flow periods in addition to normal-flow periods.

The example low-flow period of October 1980 through June 1981 was chosen because it occurred near the end of the 1974-82 drought. The 1974-82 drought was a less intense but more extended drought than the 1988-92 drought (fig. 3F) and, therefore, allowed for a better test of the water budget to estimate downstream flow for these conditions. The example extreme low-flow period of October 1990 through May 1992 is the only extreme low-flow period that occurred within water years 1981-95. During 18 of the 20 months in this extreme low-flow period, the monthly streamflow at Concordia, Kansas, was less than the MDS (fig. 4B). Within the extreme low-flow period, July through August 1991 and September through October 1991 were identified as the critical irrigation period and the lowest flow period, respectively (fig. 9). During the critical irrigaiton period, upstream and downstream flow were low and irrigation demand was high. Streamflow at Concordia, Kansas, was only about 28 percent of MDS during the lowest flow period. 


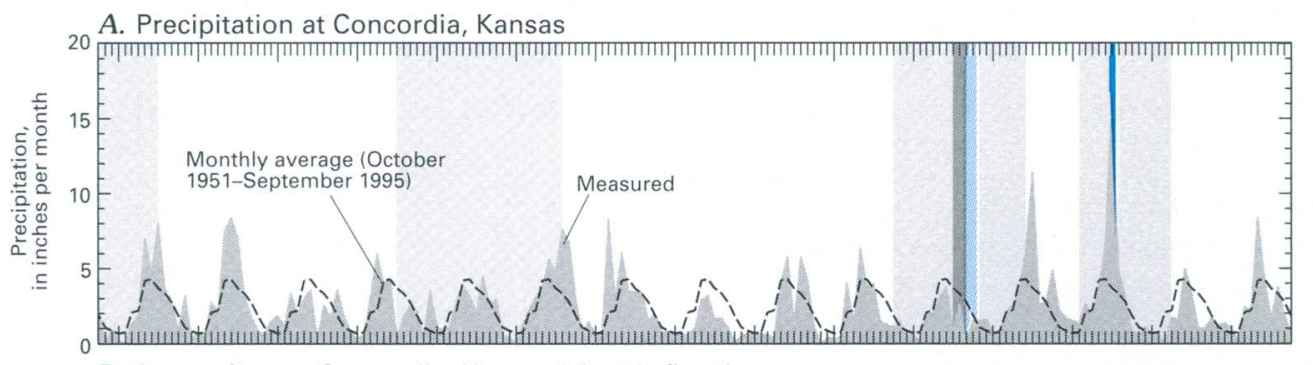

B. Streamflow at Concordia, Kansas (site 21, fig. 1)

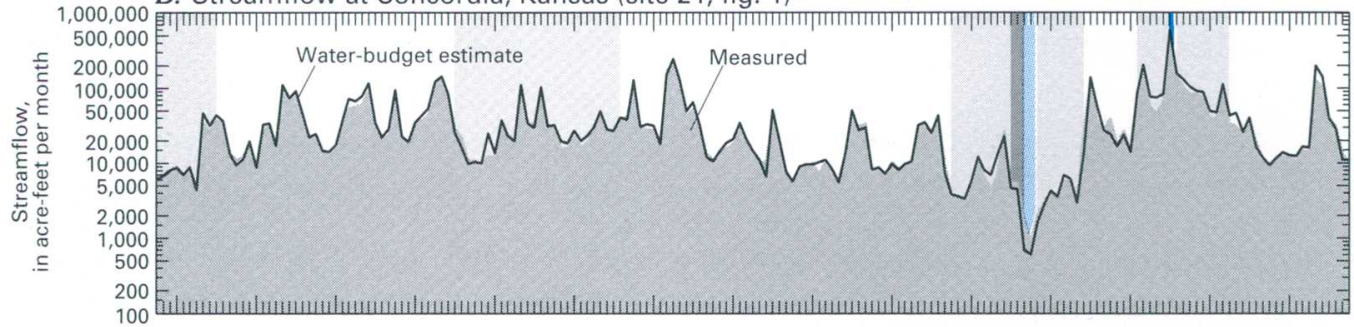

C. Difference between estimated and measured streamflow at Concordia, Kansas (site 21, fig. 1

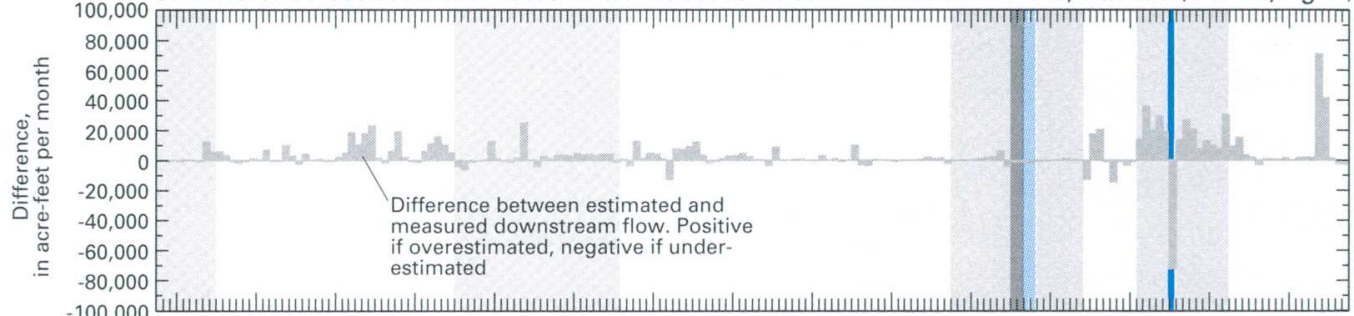

D. Difference between estimated and measured streamflow at Concordia, Kansas (site 21, fig. 1

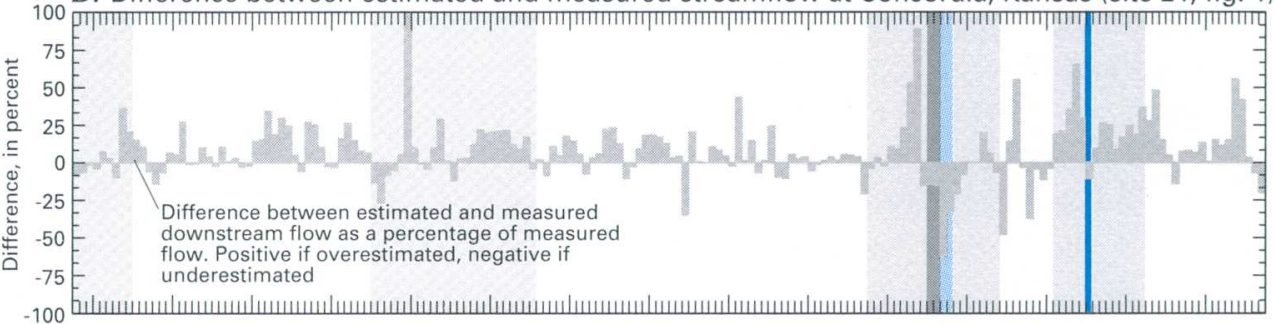

E. Drought index, north-central Kansas

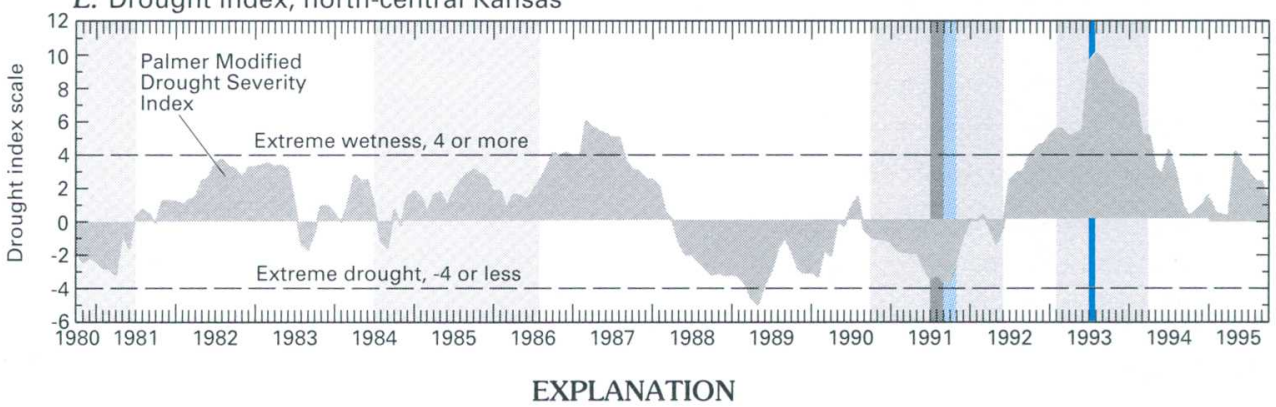

Example streamflow-class periods

Low flow-October 1980-June 1981

Normal flow-July 1984-July 1986

Extreme low flow-October 1990-May 1992

High flow-February 1993-March 1994

$\square$ Critical irrigation-July 1991-August 1991
$\square$ Lowest flow-September 1991-October 1991
Highest flow-July 1993

Figure 9. (A) Monthly precipitation, (B) estimated and measured streamflow, and difference between estimated and measured streamflow by $(C)$ volume and $(D)$ percent at Concordia, Kansas, and (E) Palmer Modified Drought Severity Index for north-central Kansas, with example streamflow-class periods, October 1980-September 1995 (sources: $A$, precipitation data from National Climatic Data Center, Asheville, North Carolina; $B, C$, and $D$, streamflow data from U.S. Geological Survey, Lawrence, Kansas; and E, Palmer Modified Drought Severity Index from National Climatic Data Center, Asheville, North Carolina). 
Table 3. Average monthly precipitation, estimated water-budget components, and measured and estimated downstream flow for example streamflow-class periods, October 1980-September 1995

[All values in table are average monthly values-precipitation values are in inches per month; measured and estimated values of water-budget components and downstream flow are in acre-feet per month; percentages are from average monthly values; <, less than. Sources: precipitation data from National Climatic Data Center, Asheville, North Carolina; streamflow data from U.S. Geological Survey, Lawrence, Kansas; evaporation data from National Oceanic and Atmospheric Administration, 1958-96; canal discharge data from Kansas Bostwick Irrigation District, Courtland, Kansas; surface-water diversion data from Kansas Department of Agriculture, Division of Water Resources, Topeka, Kansas]

\begin{tabular}{|c|c|c|c|c|c|c|c|c|}
\hline \multirow[b]{2}{*}{$\begin{array}{l}\text { Precipitation, water- } \\
\text { budget components, } \\
\text { and downstream flow }\end{array}$} & \multirow[b]{2}{*}{$\begin{array}{c}\text { October } \\
1980- \\
\text { Sep- } \\
\text { tember } \\
1995\end{array}$} & \multicolumn{2}{|c|}{ High-flow period } & \multirow{2}{*}{$\begin{array}{c}\begin{array}{c}\text { Normal- } \\
\text { flow } \\
\text { period }\end{array} \\
\\
\\
\text { July } \\
1984- \\
\text { July } \\
1986\end{array}$} & \multirow{2}{*}{$\begin{array}{c}\begin{array}{c}\text { Low- } \\
\text { flow } \\
\text { period }\end{array} \\
\\
\\
\text { October } \\
1980- \\
\text { June } \\
1981\end{array}$} & \multicolumn{3}{|c|}{ Extreme low-flow period } \\
\hline & & $\begin{array}{c}\text { Febru- } \\
\text { ary } \\
1993- \\
\text { March } \\
1994\end{array}$ & $\begin{array}{l}\text { Highest } \\
\text { flow } \\
\text { period } \\
\text { July } \\
1993\end{array}$ & & & $\begin{array}{l}\text { October } \\
1990- \\
\text { May } \\
1992\end{array}$ & $\begin{array}{c}\text { Critical } \\
\text { irrigation } \\
\text { period } \\
\text { July- } \\
\text { August } \\
1991\end{array}$ & $\begin{array}{c}\text { Lowest } \\
\text { flow } \\
\text { period } \\
\text { Sep- } \\
\text { tember- } \\
\text { October } \\
1991\end{array}$ \\
\hline \multicolumn{9}{|l|}{ Precipitation (inches per month) } \\
\hline Concordia, Kansas & 2.47 & 3.17 & 16.75 & 2.27 & 2.00 & 1.63 & 1.73 & 0.85 \\
\hline \multicolumn{9}{|c|}{ Estimated water-budget components and measured and estimated downstream flow (acre-feet per month) } \\
\hline Upstream flow & 19,477 & 61,767 & 195,740 & 14,545 & 8,025 & 3,506 & 3,460 & 976 \\
\hline Tributary flow & 12,368 & 46,093 & 269,730 & 8,862 & 3,938 & 1,076 & 12 & 2 \\
\hline Streambed seepage & 6,220 & 15,514 & 76,108 & 5,497 & 1,594 & 1,548 & 2,112 & ${ }^{1}-70$ \\
\hline Evaporation $^{2}$ & 167 & 113 & 294 & 192 & 141 & 148 & 408 & 260 \\
\hline Reservoir releases & 2,368 & 12,029 & 45,160 & 2,054 & 708 & $<1$ & 0 & 0 \\
\hline Canal return flow & 553 & 265 & 1,467 & 814 & 216 & 245 & 1,914 & 0 \\
\hline Surface-water diversions ${ }^{2}$ & 353 & 38 & $<1$ & 558 & 83 & 317 & 2,538 & $\cdot 0$ \\
\hline Downstream flow (measured) & 36,740 & 122,993 & 660,321 & 28,585 & 12,425 & 5,658 & 5,358 & 1,380 \\
\hline $\begin{array}{l}\text { Water-budget estimate } \\
\text { of downstream flow }\end{array}$ & 40,466 & 135,517 & 587,911 & 31,022 & 14,257 & 5,911 & 4,552 & 648 \\
\hline \multicolumn{9}{|c|}{ Estimated water-budget components as a percentage of water-budget estimate } \\
\hline Upstream flow & 48.1 & 45.6 & 33.3 & 46.9 & 56.3 & 59.3 & 76.0 & 150.6 \\
\hline Tributary flow & 30.6 & 34.0 & 45.9 & 28.6 & 27.6 & 18.2 & .3 & .3 \\
\hline Streambed seepage & 15.4 & 11.4 & 12.9 & 17.7 & 11.2 & 26.2 & 46.4 & ${ }^{1}-10.8$ \\
\hline Evaporation $^{2}$ & .4 & .1 & $<.1$ & .6 & 1.0 & 2.5 & 9.0 & 40.1 \\
\hline Reservoir releases & 5.9 & 8.9 & 7.7 & 6.6 & 5.0 & $<.1$ & 0 & 0 \\
\hline Canal return flow & 1.4 & .2 & .2 & 2.6 & 1.5 & 4.1 & 42.0 & 0 \\
\hline Surface-water diversions ${ }^{2}$ & .9 & $<.1$ & $<.1$ & 1.8 & .6 & 5.4 & 55.7 & 0 \\
\hline \multicolumn{9}{|c|}{ Water-budget estimate as a percentage of downstream flow } \\
\hline $\begin{array}{l}\text { Water-budget estimate } \\
\text { of downstream flow }\end{array}$ & 110.1 & 110.2 & 89.0 & 108.5 & 114.7 & 104.5 & 85.0 & 47.0 \\
\hline
\end{tabular}

${ }^{1}$ Negative streambed seepage value indicates seepage is from stream to adjacent aquifer.

${ }^{2}$ Evaporation and surface-water diversions are removals from the system when combining the components of flow to make water-budget estimates.

\section{Comparison of Water-Budget Components With Water-Budget Estimates and Measured Downstream Flow During Streamflow-Class Periods}

Table 3 shows each water-budget component for each streamflow-class period and the comparison with the monthly streamflow recorded at the gaging station at Concordia, Kansas. Also, the proportion that each major component contributes to the flow in the Republican River was computed as a percentage of the water-budget estimate for each period. Table 5, in the "Supplemental Information" section, presents estimates of the water budget and major components for each month during October 1980 through September 1995; monthly measured downstream flow, MDS, and precipitation at Concordia, Kansas, are included in table 5 for comparison purposes. 
The water-budget components that are less affected by human activity within the study area (upstream flow, tributary flow, streambed seepage, and evaporation) contributed the largest part of the waterbudget estimate-averaging about 94 percent of the monthly water-budget estimates for water years 1981-95 when combined (table 3). Except during the extreme low-flow period, this combined percentage was relatively constant, ranging from about 91 percent during the high-flow period to about 94 percent during the low-flow period. During the extreme low-flow period, the proportion of the water-budget estimates represented by components that are less affected by human activity was about 101 percent but increased to about 114 percent during the critical irrigation period when the contributions from canal return flow and streambed seepage represented atypically large proportions of the water budget. The proportion of the water budget represented by components that are less affected by human activity decreased to about 100 percent during the lowest flow period when streambed seepage became negative and the contributions from other components that commonly provide water to the budget were small or zero (table 3).

The components that are more affected by human activity within the study area (reservoir releases, canal return flow, and surface-water diversions) collectively were generally a small proportion of the water-budget estimates, averaging about 6 percent when combined for water years 1981-95. These components typically do not occur during all months of any year. For example, canal return flow generally only occurred during months in which irrigation was allowed to take place (June-September) in KBID, and surface-water diversions for irrigation were assumed for this study to occur during the same months as irrigation deliveries were made by KBID. Releases from Lovewell Reservoir do not occur on a regular schedule and are mostly dependent on the amount of precipitation that occurred during or preceding the release period. Individually, the components that are more affected by human activity can become important, especially during periods within the irrigation season (table 3 ). During those periods, they collectively may represent a substantial percentage removal from the system when making water-budget estimates (table 3 ).

\section{Upstream Flow}

Upstream flow was commonly the largest contributor to the water-budget estimates, averaging about
48 percent of the water-budget estimate for water years 1981-95 (table 3). The percentage of the water budget that upstream flow contributes varied throughout the year, typically being greatest, about 61 to 69 percent of the water budget, during the months of November through January. During those months, there generally was no irrigation or associated canal return flow, and tributary flow was small-in part because precipitation was only about 10 pecent of the long-term (October 1951-September 1995) average annual amount (table 4). During the months of September, October, February, and March, upstream flow decreased to about 49 to 56 percent of the water-budget estimate; during these months, precipitation was about 26 percent of the long-term average annual amount (table 4), and tributary flow increased, but little or no irrigation or canal return flow occurred because most plants were dormant or at the beginning or end of their growing cycle. Upstream flow further decreased to only about 41 to 45 percent of the waterbudget estimate during the months of April through August when precipitation increased to about 70 percent of the long-term average annual amount (table 4), resulting in increases in the contributions from tributary flow and streambed seepage; also, most irrigation took place during these months, resulting in more canal return flow.

Upstream flow was about 151 percent of the water-budget estimate and of greatest relative significance during the lowest flow period-even though upstream flow was only about 6 percent of the longterm monthly average for September-October and precipitation was about 37 percent of the long-term monthly average for September-October at Concordia, Kansas (tables 3 and 4). During the highest flow period, when upstream flow was at its greatest (about 560 percent of the long-term average for July) and flooding occurred in the study area, upstream flow was only about 33 percent of the water-budget estimate and of lesser significance than during any other example period (tables 3 and 4).

During the normal-flow period, upstream flow was about 47 percent of the water-budget estimate and about 68 percent of the long-term monthly average upstream flow (tables 3 and 4). Although precipitation and upstream flow increased to about 138 and 290 percent of their respective long-term averages during the high-flow period, upstream flow remained about 46 percent of the water-budget estimate (tables 3 and 4). During the low-flow period, upstream flow was 
Table 4. Average monthly and annual precipitation at Concordia, Kansas, and streamflow near Hardy, Nebraska, and at Concordia, Kansas, during October 1951-September 1995 and October 1980-September 1995

\begin{tabular}{|c|c|c|c|c|c|c|}
\hline \multirow{3}{*}{$\begin{array}{l}\text { Period of } \\
\text { average }\end{array}$} & \multicolumn{3}{|c|}{$\begin{array}{c}\text { Long-term average } \\
\text { (October 1951-September 1995) }\end{array}$} & \multicolumn{3}{|c|}{$\begin{array}{l}\text { Period of data used for this study } \\
\text { (October 1980-September 1995) }\end{array}$} \\
\hline & \multirow{2}{*}{$\begin{array}{c}\text { Precipitation } \\
\text { at Concordla, } \\
\text { Kansas }\end{array}$} & \multicolumn{2}{|c|}{ Streamflow } & \multirow{2}{*}{$\begin{array}{l}\text { Precipitation } \\
\text { at Concordia, } \\
\text { Kansas }\end{array}$} & \multicolumn{2}{|c|}{ Streamflow } \\
\hline & & $\begin{array}{c}\text { Near Hardy, } \\
\text { Nebraska }\end{array}$ & $\begin{array}{l}\text { At Concordia, } \\
\text { Kansas }\end{array}$ & & $\begin{array}{l}\text { Near Hardy, } \\
\text { Nebraska }\end{array}$ & $\begin{array}{l}\text { At Concordia, } \\
\text { Kansas }\end{array}$ \\
\hline \multicolumn{7}{|l|}{ Monthly } \\
\hline January & 0.65 & 11,710 & 15,842 & 0.72 & 10,910 & 16,383 \\
\hline February & .75 & 18,117 & 25,676 & .65 & 14,262 & 23,739 \\
\hline March & 2.06 & 26,296 & 42,735 & 2.44 & 24,673 & 44,408 \\
\hline April & 2.19 & 25,695 & 39,815 & 2.24 & 19,777 & 40,959 \\
\hline May & 4.20 & 29,594 & 47,201 & 4.55 & 31,763 & 56,253 \\
\hline June & 4.27 & 33,322 & 53,874 & 4.82 & 22,518 & 44,209 \\
\hline July & 3.67 & 35,040 & 62,925 & 4.44 & 34,348 & 85,426 \\
\hline August & 3.33 & 18,480 & 35,124 & 3.36 & 18,888 & 41,264 \\
\hline September & 2.74 & 18,157 & 33,096 & 2.33 & 13,902 & 24,218 \\
\hline October & 1.85 & 16,556 & 29,400 & 1.90 & 17,604 & 28,850 \\
\hline November & 1.07 & 12,986 & 18,806 & 1.02 & 12,598 & 17,168 \\
\hline December & .84 & 12,120 & 16,174 & 1.14 & 12,485 & 18,002 \\
\hline All months & 2.30 & 21,506 & 35,056 & 2.47 & 19,477 & 36,740 \\
\hline Annual & 27.62 & 258,071 & 420,668 & 29.61 & 233,726 & 440,878 \\
\hline
\end{tabular}

${ }^{1}$ Streamflow adjusted 1 day for traveltime to Concordia.

about 56 percent of the water-budget estimate when precipitation was about 100 percent of the long-term monthly average for October-June at Concordia and upstream flow was only about 39 percent of the longterm monthly average for October-June (tables 3 and 4). Upstream flow was a larger-than-average percentage of the water-budget estimate during periods of low to lowest flow when streamflow and precipitation were average to smaller-than-average percentages of the long-term norms (tables 3 and 4). This would seem to indicate that, while always important, preserving upstream flow is especially important during times of drought.

\section{Tributary Flow}

Tributary flow was generally the second largest water-budget component and can be a major contributor to the water budget, especially when evapotranspiration is low (winter and early spring) or when precipitation is consistently about $2 \mathrm{in} / \mathrm{mo}$ or more (Hansen, 1997). Tributary flow averaged about 31 percent of the water-budget estimate but varied greatly. Average monthly tributary flow generally was more, ranging from about 31 to 38 percent of the water-budget estimates during the months of March through July when about 55 percent of the annual precipitation took place (table 4).

Tributary flow was about 46 percent of the water budget during the highest flow period when precipitation was about 460 percent of the long-term average for July (tables 3 and 4); this was a larger percentage of the water budget than during any other example period and an even greater percentage than the upstream flow contribution to the water budget (table 3). Tributary flow contributed practically nothing (about 0.3 percent) to the water-budget estimates during the critical irrigation and lowest flow periods (table 3) when precipitation was only about 49 and 37 percent of the long-term monthly averages for July-August and September-October, respectively (tables 3 and 4). Tributary flow can contribute substantial amounts to the water-budget estimates, especially 
during periods of higher flow; however, it cannot be considered a reliable source of water during the critical irrigation months of July and August or during periods when precipitation is consistently much less than normal.

\section{Streambed Seepage}

Streambed seepage generally was positive, indicating that the Republican River is a gaining stream - that is, ground water flows into the river from the adjacent aquifer because the water table is higher than the water level in the river (fig. 2; table 3). A negative streambed-seepage estimate indicates that this situation is reversed and that the river is losing water to the aquifer (for example, lowest flow period in table 3). Streambed seepage generally was the third largest water-budget component and averaged about 15 percent of the water-budget estimates during water years 1981-95. The largest proportion of the waterbudget estimate represented by streambed seepage was about 46 percent during the critical irrigation period; this was probably due to a raised water table resulting from the use of imported surface water irrigation. Streambed seepage represented the smallest proportion of the water-budget estimate (about -11 percent) during the lowest flow period when the Republican River probably became a losing stream.

In general, the importance of streambed seepage is inversely related to the amount of downstream flow, being less important during periods of high flow when contributions from other sources, especially tributary flow, are larger, and being more important during periods of extreme low flow when the tributary flow contribution is small. However, if low-flow conditions are severe enough, streambed seepage may change from a substantial contribution to the water budget to a withdrawal (removal) from it, as may have happened during the period of lowest flow (table 3). Although streambed seepage can contribute substantially to the water-budget estimates during most of a drought, the potential to result in removals from the water-budget estimates means it cannot be considered a reliable source of water during periods of extended drought when streamflow is similar to that during the example lowest flow period.

\section{Evaporation}

Evaporation from the Republican River commonly averaged about 0.4 percent of the water-budget estimates for water years 1981-95 and ranged from about 40 percent of the water budget during the lowest flow period to less than 0.1 percent during the highest flow period (table 3). Evaporation was recorded as occurring in 103 of the 180 months in water years 1981-95-generally only in April through October of any year; for those 103 months, evaporation averaged about 0.6 percent of the water-budget estimates.

Although evaporation is described here and in table 3 as positive numbers, it is a withdrawal of water from the system and is subtracted from the total of the other components used for the water-budget estimates.

Evaporation from the Republican River was 1 percent or less except during the extreme low-flow, critical irrigation, and lowest flow periods, when it was about 2,9 , and 40 percent, respectively. Although the withdrawals from the water-budget estimates represented by evaporation from the Republican River typically were not substantial, these withdrawals may become important during drought periods in the warm season, especially during periods when streambed seepage represents withdrawals from-rather than contributions to - the water-budget estimates and contributions from all other components to the water budget are small or nonexistent.

\section{Reservoir Releases}

Reservoir releases averaged about 6 percent of the water-budget estimates for water years 1981-95 and ranged from an average of 0 percent during the critical irrigation and lowest flow periods when no releases occurred to about 9 percent during the high-flow period (table 3 ). Reservoir releases are sporadic and generally do not occur during all months of a year or of a flow period. Reservoir releases typically are made only during or following periods when precipitation is above average or during the nongrowing season (most likely to lower the level of the reservoir in anticipation of increased runoff during the following spring).

Releases were made in only 52 months of the 180 months in water years 1981-95, and for those months with releases, the average release was about 9 percent of the water-budget estimates.

During water years 1981-95, the longest period when reservoir releases were made during consecutive months was February 1993 through May 1994, which includes the example period of high flow (table 3 ).

During the period of high flow, the average amount of reservoir release was about 510 percent of the average for water years 1981-95 (table 3) and about 150 per- 
cent of the average for all months with releases. Precipitation during the high-flow period was about onethird greater than the average for water years 1981-95 (table 3 ) and was preceded by a 9-month period of predominately above-average precipitation (fig. 9A). During July 1993, the period of highest flow, the amount of reservoir releases was about 550 percent of the average for months with releases, and precipitation was about 450 percent of the long-term average of $3.67 \mathrm{in}$. for the month of July.

During water years 1981-95, the longest period with very small or no releases was during April 1988 through June 1992, which included the extreme lowflow period (table 3); the only month with an appreciable release was June 1991 when precipitation was about 3.77 in. Even with the much reduced Republican River streamflow during June 1991, reservoir releases were still less than 0.1 percent of the water-budget estimate. Reservoir releases, because they are sporadic and typically occur only during or immediately following periods when precipitation is above average or in anticipation of a need for spring flood control, generally are unimportant to streamflow in the Republican River during periods of extreme low flow when water in reservoirs is almost always conserved rather than released.

\section{Canal Return Flow}

Canal return flow averaged about 1 percent of the water-budget estimates for water years 1981-95 and ranged from 0 percent during the lowest flow period to about 42 percent during the critical irrigation period (table 3). Canal return flows only occurred in 58 out of 180 months during water years 1981-95; for those 58 months, canal return flow averaged about 3 percent of the water-budget estimates.

Canal return flow was most important, about 42 percent of the water-budget estimate, during the critical irrigation period, when use of surface water for irrigation was restricted by KBID. As a result, the amounts of water diverted for KBID and the corresponding canal return flow, especially during the months of July and August 1991, may have been much less both in amount and percentage of the water-budget estimate than if the restrictions had not existed. This illustrates the large effect canal return flow may have on the water-budget estimates during the irrigation season during periods of extreme low flow.

Average canal return flow during the highest flow period was only about 0.2 percent, the smallest per- centage shown in table 3 for any of the periods when canal return flow took place. However, the average amount of canal return flow during the highest flow period approached that during the critical irrigation period (table 3), even though the amount of water diverted for irrigation was much less during the former period than during the latter one (data on file with KBID, Courtland, Kansas). The relatively large canal return flow during the highest flow period probably is due to the canals acting as tributaries and routing excess runoff from precipitation to the Republican River. Although canal return flow was zero during most months, during the months it occurred canal return flow generally increased both in amount and as a percentage of the water-budget estimates as upstream and downstream flow decreased; therefore, canal return flow can be an important source of water to the Republican River during the irrigation season when streamflow is similar to that during the example extreme low-flow period.

\section{Surface-Water Diversions}

Surface-water diversions generally were small, averaging about 1 percent of the water-budget estimate for water years 1981-95 and ranged from 0 percent during the lowest flow period to about 56 percent during the critical irrigation period (table 3 ). Surfacewater diversions were considered to have occurred during only 57 out of 180 months during water years 1981-95; for those 57 months, surface-water diversions averaged about 3 percent of the water-budget estimates. Although surface-water diversions are described here and in table 3 as positive numbers, they are withdrawals of water from the system and are subtracted from the total of the other components used for the water-budget estimates.

By far the largest average amount of surface-water diversions and corresponding percentage of the waterbudget estimate-about 56 percent-occurred during the critical irrigation period (table 3). Surface-water diversions were both about one-third more than the amount of canal return flow during this period and larger than the sum of reservoir releases and canal return flow-resulting in a net loss to the water-budget estimate of about 14 percent from the components that are more affected by human activity within the study area (table 3). Surface-water diversions also were more than the sum of reservoir releases and canal return flow during the extreme low-flow period, resulting in a very small net loss to the water budget from 
components that are more affected by human activity (table 3).

Surface-water diversions were equivalent to zero in amount and percentage of the water-budget estimates during the lowest flow period (table 3 ). Surfacewater diversions were not considered to have occurred during the lowest flow period because no deliveries were reported by KBID during this flow period. Although July is usually the height of the irrigation season, no surface-water diversions were considered to have taken place during the highest flow period because no deliveries were reported by KBID; considering precipitation was about 450 percent of the longterm average for July (tables 3 and 4), this was reasonable. Although surface-water diversions generally are small and typically less than the sum of the other components that are more affected by human activity within the study area, surface-water diversions tend to increase as streamflow decreases and can result in large percentage withdrawals of water from the water budget during the irrigation season when streamflow is similar to that during the example extreme low-flow period.

\section{Downstream Flow}

Downstream flow provides a measure of how well the mass-balance water-budget estimates compared to measured streamflow at Concordia, Kansas. The water-budget estimate averaged about 110 percent of measured downstream flow for water years 1981-95 (table 3), indicating that the water budget tended to overestimate the downstream flow by an average of about 10 percent with a standard deviation of about 20 percent. This tendency of the water budget to overestimate downstream flow can be seen in figure $9 C$ and $D$ and graphically for streamflows greater than about 40,000 acre-ft/mo in figure 10 .

The water-budget estimates varied least in percentage from downstream flow during the extreme low-flow and normal-flow periods when the waterbudget estimates were about 104 and 108 percent of downstream flow, respectively (table 3 ), with standard deviations of about 31 and 24 percent, respectively. The water-budget estimate exceeded downstream flow by the largest percentage during the low-flow period when it was about 115 percent of the downstream flow (table 3), with a standard deviation of about 15 percent. However, during the highest and lowest flow periods, when downstream flow was about 1,050 and 4 percent of their respective long-term monthly aver- ages (tables 3 and 4), the water-budget estimates were only about 89 and 47 percent of downstream flow, respectively (table 3 ), indicating that the water budget tended to underestimate the amount of downstream flow when downstream flow varied greatly from normal. This tendency to underestimate extreme streamflow values can be seen graphically in figure 10 .

The water-budget estimates of downstream flow generally are comparable to measured downstream flow (fig. 9B). This is confirmed by the strong correlation ( $r$ equal to 0.983 ) of measured downstream flow with the water-budget estimates, which indicates that the water budget provides relatively good estimates of downstream flow (fig. 10).

There are many potential sources of error that may cause the difference between the measured downstream flow and water-budget estimates. The largest potential errors are associated with the estimated components of the water-budget estimates that are less affected by human activity within the study area because they generally contribute more than 90 percent of the water budget (table 3); smaller potential errors are associated with the components that are more affected by human activity, although these errors may be important when these components become substantial parts of the water-budget estimates.

Even good measurements of streamflow generally have an estimated error of 5 percent, and this error typically increases to about 8 percent for streams with loose sand or mud streambeds, such as the Republican River and its tributaries in the study area (Dennis Lacock, U.S. Geological Survey, oral commun., 1997). These potential errors affect not only downstream flow, to which the water-budget estimates are compared, but also upstream and tributary flow components.

The streambed seepage component is a potentially large source of error in the water-budget estimates because, except for the 10 sets of synoptic seepagesurvey measurements used in this study, no measured data existed in the study area for this component. Streambed seepage probably was overestimated when, for extended periods, tributary flow was large or when canal return flow or reservoir releases were a large proportion of the water budget. This is because the hydrograph-separation techniques used by the BFI4 computer program to estimate the streambed seepage component are general estimation methods that use the total flow measured at a point and assume all flow is from unregulated sources. Contributions, especially 


\section{EXPLANATION}

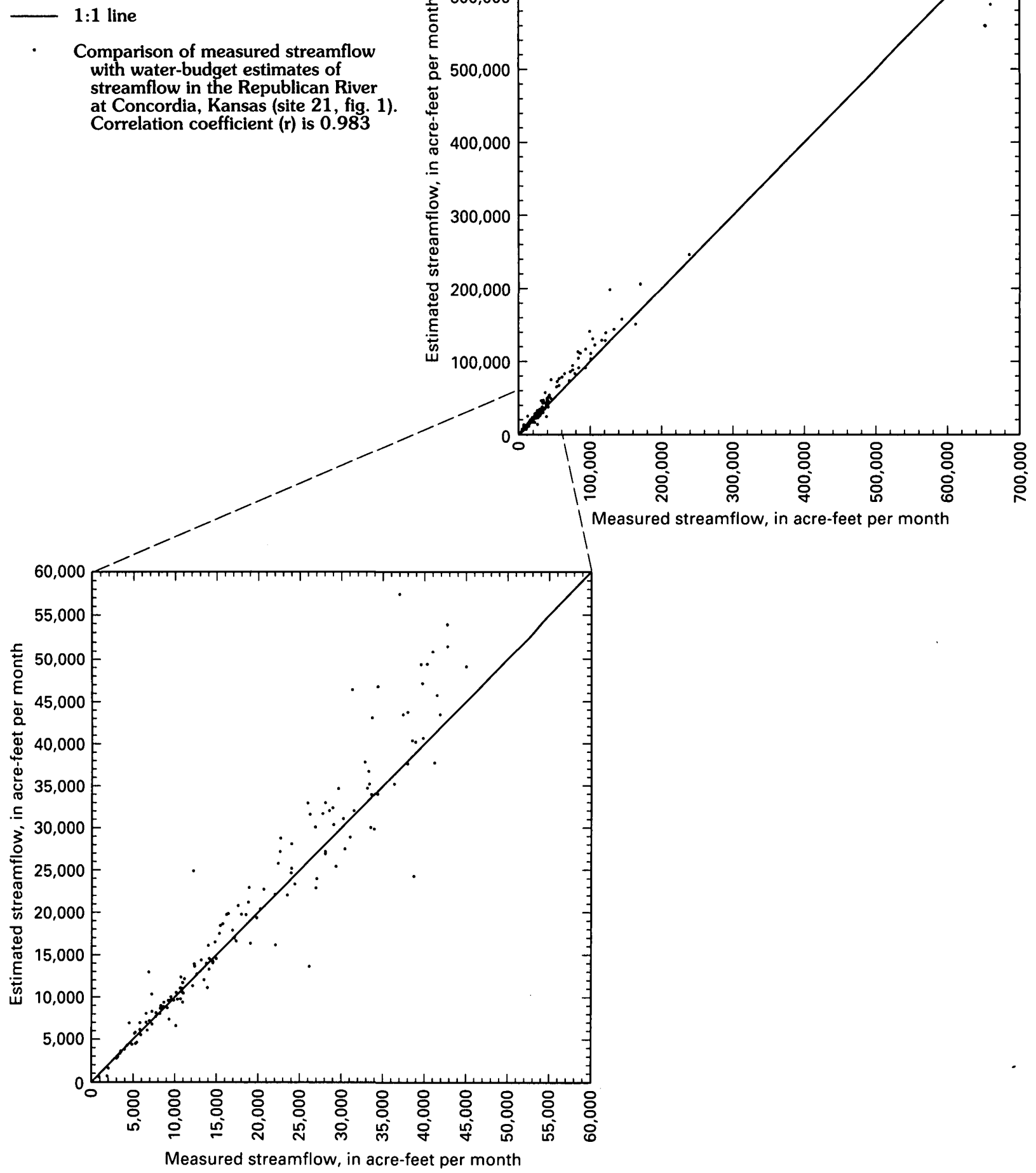

Figure 10. Comparison of measured streamflow with water-budget estimates of streamflow in Republican River at Concordia, Kansas, October 1980-September 1995 (source: U.S. Geological Survey, Lawrence, Kansas).

from regulated sources such as canal return flow or reservoir releases within the study area or undiverted reservoir releases from Harlan County Dam upstream from the study area, that occur for periods longer than the minimum increment test interval ( 7 days), are considered part of the streamflow from which streambed seepage is estimated by the BFI4 program and can cause streambed seepage to be overestimated. 
Another potentially large source of error in the water-budget estimates is the tributary flow component. The ungaged part of the study area that contributed to the tributary flow component increased from about 42 to about 70 percent following June 1990 when the gaging station on Buffalo Creek near Jamestown was removed. Despite the strong correlation between the measured and estimated streamflow at the gaging station on Buffalo Creek near Jamestown, the divergence of the data points from the one-to-one line in figure 5 indicates that there may be relatively large errors associated with the estimates of streamflow in Buffalo Creek during July 1990 through September 1995. The area that was ungaged for all of water years 1981-95, especially that part east of the Republican River, is drained by tributaries that are smaller than those that were measured at streamflowgaging stations in the study area; this may have resulted in an overestimate of tributary flow during much of water years 1981-95.

The reservoir release component may have been slightly underestimated, as some of the average daily streamflow less than $10 \mathrm{ft}^{3} / \mathrm{s}$ measured at the gage on White Rock Creek at Lovewell, Kansas, that was assigned to tributary flow, may have been due to releases from Lovewell Reservoir instead. Errors in reservoir releases also may have resulted in a small error in the streambed seepage component as the estimated daily reservoir releases (after adjusting 2 days for traveltime) were subtracted from downstream flow before the BFI4 computer program was used to estimate streambed seepage at Concordia, Kansas.

The relatively small potential errors associated with the canal return flow, surface-water diversions, and evaporation components are from several sources. Canal return flow may have been underestimated because the assumption was made that all canal return flow from KBID was measured; however, some canal return flow probably drained into tributaries in the ungaged part of the study area where it was neither measured nor included in the estimates of tributary flow. This may account, in part, for the underestimate of downstream flow during the critical irrigation period (table 3, fig. $9 B-D$ ).

Errors in estimates of surface-water diversions may exist because they were based on data from annual water-use reports completed and returned to DWR by users and because monthly surface-water diversions were assumed to occur in the same monthly-to-annual proportions as deliveries made by
KBID. This assumption may have resulted in underestimation of the surface-water diversion component during the months KBID does not allow irrigation (October-May) and overestimation during those months KBID allowed irrigation (June-September), especially during the extreme low-flow period when KBID had to restrict the amount of water available for irrigation. The estimates of evaporation used in this study may have errors associated with them primarily because pan evaporation typically was not measured during November through March and because an estimated constant width of the Republican River was used. The constant river width probably resulted in the evaporation component being overestimated during the critical irrigation and lowest flow periods when this component represented substantial removals from the water-budget estimates.

\section{SUMMARY}

Kansas, Nebraska, and Colorado formed the Republican River Compact in 1942 to allocate the water in the Republican River Basin among the three States. The regulation of the Republican River, which largely began in the 1950's, has decreased average streamflow at the gaging station near Hardy, Nebraska, reduced the frequency of flooding, and provided water for irrigation. Kansas Bostwick Irrigation District, which began full operation in 1958, uses water released from Harlan County Dam for irrigation; the canal return flow contributes to increased streamflow in the Republican River during all or part of the irrigation season (June through September).

The greatly increased water use in the basin, which began in the 1950's, has caused concern by the State of Kansas regarding the compliance of the compact conditions by Nebraska at the State line, the maintenance of streamflow greater than the MDS at Concordia, Kansas, and the ensurance of an adequate water supply in Milford Lake to fulfill the needs of downstream users. To help address these regional concerns, this report presents the results of a 4-year study by the USGS, in cooperation with the Kansas Water Office and funded in part by the Kansas State Water Plan Fund, to quantify the effects of major water-budget components on streamflow in the Republican River from near Hardy, Nebraska, to Concordia, Kansas, for October 1980 through September 1995.

A mass-balance model was used to study the effects of major water-budget components on stream- 
flow. Upstream flow into the study reach, tributary inflow, streambed seepage, evaporation, reservoir releases, irrigation canal return flow, and surfacewater diversions were considered major water-budget components for the model. Monthly water-budget estimates were compared to measured discharge of the Republican River at Concordia during four streamflow-class periods-high-flow, normal-flow, low-flow, and extreme low-flow conditions-to quantify how well the water-budget estimates matched measured flows. The proportion each major component contributed to the water-budget estimates during these four streamflow-class periods was determined.

The components of streamflow that are less affected by human activity within the study area (upstream flow, tributary flow, streambed seepage, and evaporation) typically contributed the largest part of the water-budget estimates—averaging about 94 percent of the monthly water-budget estimates for water years 1981-95. This combined percentage was relatively constant, ranging from about 91 percent during the high-flow period to about 101 percent during the extreme low-flow period. Upstream flow was the largest contributor to water-budget estimates, and its relative contribution during water years 1981-95 tended to increase during lower flow periods. The importance of tributary flow tended to increase as streamflow increased, but it may become insignificant during a drought. Streambed seepage generally was positive, indicating that the Republican River is typically a gaining stream. Streambed seepage typically increased in importance as streamflow decreased; however, during periods of extreme low flow, it may become negative, indicating that the river may become a losing stream. Evaporation from the Republican River, while commonly representing less than 1 percent of the water budget, can become important during periods of drought.

Components of streamflow that are more affected by human activity within the study area (reservoir releases, canal return flow, and surface-water diversions) collectively were generally a small proportion of the water-budget estimates, averaging about 6 percent when combined for water years 1981-95, and generally resulted in a small net increase in the amount of water in the water budget. These streamflow components typically do not occur during all months of any year. Individually, components that are more affected by human activity can become important, especially during the irrigation season during periods of extreme low flow. During those periods, they collectively may contribute a substantial percentage of the water-budget estimate, or collectively they may result in a loss of streamflow.

Reservoir releases generally increase as streamflow increases but typically are unimportant during drought periods because they are zero. Canal return flow typically occurs only during the months of June through September; during those months in which canal return flow occurs, its importance increases as streamflow decreases. Surface-water diversions tend to increase as streamflow decreases and may exceed the sum of reservoir releases and canal return flow during the irrigation season during extreme low-flow periods, resulting in a loss of streamflow from the components that are more affected by human activity.

Downstream flow provides a measure of how well the water-budget estimates compared to measured streamflow at Concordia, Kansas. The water-budget estimate was about 110 percent of downstream flow for the entire study period, indicating that the water budget tended to overestimate measured downstream flow by an average of about 10 percent. Comparison of the monthly water-budget estimates with downstream flow resulted in a strong correlation, indicating that the water-budget estimates are a good indicator of downstream flow.

The largest potential sources of error in the water budget are the streambed seepage and tributary flow components. The streambed seepage component probably was overestimated part of the time because the hydrograph-separation techniques used in the BFI4 computer program include any regulated contributions that continue for longer than the minimum increment test interval ( 7 days for this study) as part of the streamflow from which the streambed seepage is estimated. The tributary flow component probably was overestimated for the 42 to 70 percent of the study area that was ungaged during all or part of water years 1981-95 because it was based on gaged streamflow from tributaries that generally are larger than those in the ungaged part of the study area. Even measured streamflow can be expected to contain errors of 5 to 8 percent.

The rest of the water-budget components probably have smaller errors associated with them. For example, a small amount of error in the water budget may be due to the use of $10 \mathrm{ft}^{3} / \mathrm{s}$ average daily flow as the delineation between natural streamflow in White Rock Creek and reservoir releases from Lovewell Reservoir. 
The canal return flow component, although it was based on measured monthly values, may have been underestimated because some return flow from KBID may have remained unmeasured if it drained into ungaged tributaries instead of the KBID system of canals. It is likely that some small errors exist that are associated with the surface-water diversion component because the monthly estimates of this component were based on annual data reported to DWR by the users. Evaporation may have been underestimated part of the time because evaporation typically was not recorded during November through March and the width of the Republican River was estimated as a single value of $150 \mathrm{ft}$; however, evaporation may have been overestimated during extreme low-flow periods when the width of the river may have been less than $150 \mathrm{ft}$.

\section{SELECTED REFERENCES}

Bayne, C.K., and Walters, K.L., 1959, Geology and groundwater resources of Cloud County, Kansas: Kansas Geological Survey Bulletin 139, 144 p.

Buchanan, T.J., and Somers, W.P., 1984, Discharge measurements at gaging stations (4th ed.): U.S. Geological Survey Techniques of Water-Resources Investigations, book 3, chap. A8, 65 p.

Bureau of Reclamation, 1985a, Special report, in Republican River basin water management study-Colorado, Nebraska, Kansas: Denver, Colorado, Lower Missouri Region, $120 \mathrm{p}$.

— 1985b, Hydrology - volume 1, in Republican River basin water management study - Colorado, Nebraska, Kansas: Denver, Colorado, Lower Missouri Region, various pagination.

1985c, Hydrology - volume 2, in Republican River basin water management study - Colorado, Nebraska, Kansas: Denver, Colorado, Lower Missouri Region, various pagination.

1996, Resource management assessment Republican River basin-water service contract renewal: Grand Island, Nebraska, Great Plains Region, various pagination.

Carter, R.W., and Davidian, Jacob, 1977, General procedure for gaging streams (3d ed.): U.S. Geological Survey Techniques of Water-Resources Investigations, book 3 , chap. A6, 13 p.

Clement, R.W., 1991, Kansas floods and droughts, in Paulson, R.W., Chase, E.B., Roberts, R.S., and Moody, D.W., compilers, National water summary 1988-89-Hydrologic events and floods and droughts:
U.S. Geological Survey Water-Supply Paper 2375, p. 287-294.

Corps of Engineers, 1967, Master manual, in Republican River basin reservoir regulation manual: Kansas City, Missouri, Department of the Army, Kansas City District, v. 1 of 14 , various pagination.

Dunlap, L.E., 1982, Geohydrology of principal aquifers in the Republican River basin, Kansas: U.S. Geological Survey Open-File Report 82-79, 5 sheets, scale 1:250,000.

Fader, S.W., 1968, Ground water in the Republican River area, Cloud, Jewell, and Republic Counties, Kansas: Kansas Geological Survey Bulletin 188, 27 p.

Farnsworth, R.K., Thompson, E.S., and Peck, E.L., 1982, Evaporation atlas for the contiguous 48 United States: National Oceanic and Atmospheric Administration Technical Report NWS 33, 27 p., 4 plates, approximate scale $1: 15,000,000$.

Fenneman, N.M., 1931, Physiography of western United States: New York, McGraw-Hill Book Co., Inc., 534 p.

Fishel, V.C., 1948, Ground-water resources of Republic County and northern Cloud County, Kansas: Kansas Geological Survey Bulletin 73, 194 p.

Fishel, V.C., and Leonard, A.R., 1955, Geology and groundwater resources of Jewell County, Kansas: Kansas Geological Survey Bulletin 115, 152 p.

Hansen, C.V., 1991, Estimates of freshwater storage and potential natural recharge for principal aquifers in Kansas: U.S. Geological Survey Water-Resources Investigations Report 87-4230, $100 \mathrm{p}$.

1997, Major components of flow in the Republican River during drought conditions from near Hardy, Nebraska, to Concordia, Kansas: U.S. Geological Survey Fact Sheet FS-234-96, 6 p.

Heddinghouse, T.R., and Sabol, Paul, 1991, A review of the Palmer Drought Severity Index and where do we go from here?, in Proceedings of the Seventh Conference on Applied Climatology: Boston, Massachusetts, American Meteorological Society, p. 242-246.

Hedman, E.R., and Engel, G.B., 1989, Flow characteristics for selected streams in the Great Plains subregion of the Central Midwest Regional Aquifer System and selected adjacent areas-Kansas and Nebraska, and parts of Colorado, Iowa, Missouri, New Mexico, Oklahoma, South Dakota, Texas and Wyoming: U.S. Geological Survey Hydrologic Investigations Atlas HA-708, 3 sheets, scale 1: 1,000,000.

Helsel, D.R., and, Hirsch, R.M., 1992, Statistical methods in water resources-studies in environmental science 49: New York, Elsevier Science Publ. Co., Inc., 522 p.

Helyar, Thelma, ed., 1996, Kansas statistical abstracts 1993-94: Lawrence, Kansas, Institute for Public Policy and Business Research, University of Kansas, $416 \mathrm{p}$. 
Institute of Hydrology, 1980a, Low flow studies: Wallingford, Oxon, United Kingdom, Report No. 1, 41 p. 1980b, Low flow studies: Wallingford, Oxon, United Kingdom, Report No. 3, p. 12-19.

Kansas Water Resources Board, 1961, Section 9, Lower Republican Unit in State Water Plan studies, part A.-preliminary appraisal of Kansas water problems: Topeka, Kansas, 99 p.

Lohman, S.W., and others, 1972, Definitions of selected ground-water terms-revisions and conceptual refinements: U.S. Geological Survey Water-Supply Paper 1988, $21 \mathrm{p}$.

Missouri Basin States Association, 1982a, Ground water depletion technical paper, in Missouri River basin hydrology study: Omaha, Nebraska, various pagination.

1982b, Transmissivity and stream depletion factor maps, Platte and Kansas River basins, Colorado-Kansas-Nebraska-Wyoming-ground water depletion technical paper, Appendix II, in Missouri River basin hydrology study: Omaha, Nebraska, various pagination.

National Oceanic and Atmospheric Administration, 1958-96, Climatological data, annual summary-Kansas: Asheville, North Carolina, v. 72-110, no. 13, various pagination.

Spruill, T.B., 1985, Statistical evaluation of the effects of irrigation on chemical quality of ground water and base flow in three river valleys in north-central Kansas: U.S. Geological Survey Water-Resources Investigations Report 85-4156, 64 p.
Statware, Inc., 1990, Static statistics reference manual, release 2.3X: Corvallis, Oregon, Statware, Inc., various pagination.

Swan, D.R., and Condie, R., 1983, Computation of the base flow index: Ottawa, Ontario, Water Resources Branch Inland Water Directorate, Environment Canada, 21 p.

U.S. Geological Survey, 1980, National handbook of recommended methods for water-data acquisition, chapter 2-ground water: Reston, Virginia, various pagination.

Wahl, K.L., and Wahl, T.L.,1988, Effects of regional ground-water level declines on streamflow in the Oklahoma Panhandle, in Proceedings of the American Water Resources Association Symposium on WaterUse Data for Water Resources Management, Tucson, Arizona: $11 \mathrm{p}$.

1995, Determining the flow of Comal Springs at New Braunfels, Texas, in Proceedings of Texas Water '95, A Component Conference of the First International Conference on Water Resources Engineering: American Society of Civil Engineers, August 16-17, 1995, San Antonio, Texas, p. 77-86.

Water Resources Management, Inc., 1994, Depletion analysis and modifications of historic record for the Republican River depletion study: Prepared in cooperation with the Kansas Water Office, Topeka, Kansas, 32 p.

Wing, M.E., 1930, Geology of Cloud and Republic Counties, Kansas: Kansas Geological Survey Bulletin 15, $51 \mathrm{p}$. 
32 Effects of Water-Budget Components on Streamflow in the Republican River From Near Hardy, Nebraska, to Concordia, Kansas, October 1980-September 1995 


\section{SUPPLEMENTAL INFORMATION}


Table 5. Monthly, monthly average for water years, and average monthly water-budget estimates of components of flow and of streamflow in the Republican River from near Hardy, Nebraska, to Concordia, Kansas, compared to measured downstream flow, minimum desirable streamflow, and precipitation at Concordia, Kansas, October 1980-September 1995

[All values except precipitation are in acre-feet per month; precipitation is in inches per month]

\begin{tabular}{|c|c|c|c|c|c|c|c|c|c|c|c|c|}
\hline \multirow[b]{2}{*}{$\begin{array}{l}\text { Date } \\
\text { (year- } \\
\text { month) }\end{array}$} & \multicolumn{4}{|c|}{$\begin{array}{c}\text { Components that are less affected by } \\
\text { human activities }\end{array}$} & \multicolumn{3}{|c|}{$\begin{array}{l}\text { Components that are } \\
\text { more affected by } \\
\text { human activities }\end{array}$} & \multicolumn{3}{|c|}{$\begin{array}{l}\text { Estimated and measured } \\
\text { streamflow }\end{array}$} & \multicolumn{2}{|c|}{$\begin{array}{l}\text { Supplemental } \\
\text { data }\end{array}$} \\
\hline & $\begin{array}{l}\text { Upstream } \\
\text { flow }\end{array}$ & $\begin{array}{c}\text { Tribu- } \\
\text { tary } \\
\text { flow } 2\end{array}$ & $\begin{array}{l}\text { Stream- } \\
\text { bed } \\
\text { seep- } \\
\text { age }^{3}\end{array}$ & $\begin{array}{l}\text { Evapo- } \\
\text { ration }\end{array}$ & $\begin{array}{l}\text { Reser- } \\
\text { voir } \\
\text { release }\end{array}$ & $\begin{array}{l}\text { Canal } \\
\text { return } \\
\text { flow }^{6}\end{array}$ & $\begin{array}{l}\text { Sur- } \\
\text { face- } \\
\text { water } \\
\text { diver- } \\
\text { sions }^{7}\end{array}$ & $\begin{array}{c}\text { Water- } \\
\text { budget } \\
\text { estimate }\end{array}$ & $\begin{array}{l}\text { Mea- } \\
\text { sured } \\
\text { down- } \\
\text { stream } \\
\text { flow }^{9}\end{array}$ & $\begin{array}{c}\text { Differ- } \\
\text { ence } \\
\text { be- } \\
\text { tween } \\
\text { water- } \\
\text { budget } \\
\text { esti- } \\
\text { mate } \\
\text { and } \\
\text { down- } \\
\text { stream } \\
\text { flow } 10\end{array}$ & $\begin{array}{l}\text { Mini- } \\
\text { mum } \\
\text { desir- } \\
\text { able } \\
\text { stream- } \\
\text { flow at } \\
\text { Concor- } \\
\text { dia, } \\
\text { Kansas } \\
11\end{array}$ & $\begin{array}{c}\text { Precip- } \\
\text { itation } \\
\text { at Con- } \\
\text { cordia, } \\
\text { Kansas } \\
\mathbf{1 2}\end{array}$ \\
\hline \multicolumn{13}{|c|}{1981 water year } \\
\hline $80-10$ & 5,629 & 146 & 519 & 225 & 0 & 0 & 0 & 6,069 & 6,676 & -607 & 5,227 & 1.98 \\
\hline $80-11$ & 5,851 & 73 & 869 & 0 & 0 & 0 & 0 & 6,793 & 7,258 & -465 & 4,760 & .07 \\
\hline $80-12$ & 6,932 & 117 & 1,010 & 0 & 0 & 0 & 0 & 8,059 & 8,192 & -133 & 6,149 & .97 \\
\hline $81-01$ & 7,289 & 232 & 1,207 & 0 & 0 & 0 & 0 & 8,728 & 9,100 & -372 & 6,149 & .14 \\
\hline $81-02$ & 5,867 & 305 & 845 & 0 & 0 & 0 & 0 & 7,017 & 6,540 & 477 & 6,942 & .07 \\
\hline $81-03$ & 7,137 & 412 & 1,333 & 0 & 0 & 0 & 0 & 8,882 & 8,644 & 238 & 9,223 & 1.30 \\
\hline $81-04$ & 3,053 & 319 & 1,329 . & 312 & 0 & 0 & 3 & 4,586 & 4,860 & -474 & 8,926 & 1.85 \\
\hline $81-05$ & 21,545 & 22,022 & 3,250 & 300 & 278 & 0 & 0 & 46,794 & 34,352 & 12,442 & 9,223 & 6.98 \\
\hline $81-06$ & 8,922 & 11,817 & 3,980 & 435 & 6,097 & 1,948 & 744 & 31,585 & 26,200 & 5,385 & 8,926 & 4.68 \\
\hline $81-07$ & 23,159 & 12,504 & 7,268 & 389 & 0 & 3,149 & 1,962 & 43,729 & 37,946 & 5,783 & 9,223 & 8.02 \\
\hline $81-08$ & 18,191 & 11,049 & 6,762 & 327 & 0 & 1,587 & 562 & 36,700 & 33,244 & 3,457 & 9,223 & 3.61 \\
\hline $81-09$ & 9,624 & 1,084 & 2,583 & 283 & 0 & 380 & 94 & 13,294 & 14,101 & -807 & 4,760 & 2.75 \\
\hline \multicolumn{13}{|c|}{1982 water year } \\
\hline $81-10$ & 7,464 & 580 & 1,521 & 157 & 0 & 0 & 0 & 9,408 & 10,949 & $-1,541$ & 5,227 & .84 \\
\hline $81-11$ & 8,612 & 769 & 1,962 & 0 & 0 & 0 & 0 & 11,343 & 12,139 & -796 & 4,760 & 3.22 \\
\hline $81-12$ & 12,869 & 2,478 & 2,364 & 0 & 2,007 & 0 & 0 & 19,718 & 18,524 & 1,194 & 6,149 & .21 \\
\hline $82-01$ & 6,242 & 1,025 & 1,420 & 0 & 0 & 0 & 0 & 8,687 & 8,251 & 436 & 6,149 & .82 \\
\hline $82-02$ & 23,441 & 7,034 & 2,455 & 0 & 0 & 0 & 0 & 32,930 & 25,924 & 7,006 & 6,942 & .45 \\
\hline $82-03$ & 16,082 & 13,787 & 4,136 & 0 & 0 & 0 & 0 & 34,005 & 34,338 & -333 & 9,223 & 2.81 \\
\hline $82-04$ & 9,872 & 3,948 & 3,440 & 265 & 0 & 0 & 0 & 16,995 & 17,134 & -13.9 & 8,926 & 2.06 \\
\hline $82-05$ & 81,488 & 17,994 & 10,485 & 275 & 1,269 & 0 & 0 & 110,962 & 100,889 & 10,073 & 9,223 & 7.53 \\
\hline $82-06$ & 32,986 & 19,659 & 15,483 & 294 & 5,355 & 218 & 0 & 73,407 & 70,650 & 2,757 & 8,926 & 8.38 \\
\hline $82-07$ & 43,177 & 24,654 & 21,857 & 435 & 0 & 3,517 & 1,472 & 91,298 & 93,437 & $-2,139$ & 9,223 & 7.04 \\
\hline $82-08$ & 18,177 & 4,555 & 15,403 & 321 & 5,768 & 3,740 & 1,568 & 45,754 & 41,475 & 4,279 & 9,223 & 3.17 \\
\hline $82-09$ & 12,266 & 3,763 & 5,235 & 224 & 672 & 503 & 72 & 22,143 & 21,999 & 144 & 4,760 & 1.79 \\
\hline \multicolumn{13}{|c|}{1983 water year } \\
\hline $82-10$ & 13,036 & 7,121 & 3,904 & 177 & 766 & 0 & 0 & 24,649 & 23,943 & 706 & 5,227 & .85 \\
\hline $82-11$ & 9,574 & 2,116 & 2,860 & 0 & 0 & 0 & 0 & 14,550 & 14,973 & -423 & 4,760 & .57 \\
\hline $82-12$ & 9,084 & 2,483 & 2,666 & 0 & 0 & 0 & 0 & 14,233 & 14,559 & -326 & 6,149 & 1.52 \\
\hline $83-01$ & 11,260 & 3,340 & 2,912 & 0 & 0 & 0 & 0 & 17,512 & 15,336 & 2,176 & 6,149 & 1.84 \\
\hline $83-02$ & 18,871 & 12,204 & 6,731 & 0 & 0 & 0 & 0 & 37,806 & 32,795 & 5,011 & 6,942 & 1.09 \\
\hline $83-03$ & 38,674 & 11,428 & 22,257 & 0 & 0 & 0 & 0 & 72,359 & 53,900 & 18,459 & 9,223 & 3.42 \\
\hline $83-04$ & 38,450 & 10,280 & 18,371 & 191 & 0 & 0 & 0 & 66,910 & 56,431 & 10,479 & 8,926 & 1.92 \\
\hline
\end{tabular}

34 Effects of Water-Budget Components on Streamflow in the Republican River From Near Hardy, Nebraska, to Concordia, Kansas, October 1980-September 1995 
Table 5. Monthly, monthly average for water years, and average monthly water-budget estimates of components of flow and of streamflow in the Republican River from near Hardy, Nebraska, to Concordia, Kansas, compared to measured downstream flow, minimum desirable streamflow, and precipitation at Concordia, Kansas, October 1980-September 1995-Continued

\begin{tabular}{|c|c|c|c|c|c|c|c|c|c|c|c|c|}
\hline \multirow[b]{2}{*}{$\begin{array}{l}\text { Date } \\
\text { (year- } \\
\text { month) }\end{array}$} & \multicolumn{4}{|c|}{$\begin{array}{c}\text { Components that are less affected by } \\
\text { human activities }\end{array}$} & \multicolumn{3}{|c|}{$\begin{array}{l}\text { Components that are } \\
\text { more affected by } \\
\text { human activities }\end{array}$} & \multicolumn{3}{|c|}{$\begin{array}{l}\text { Estimated and measured } \\
\text { streamflow }\end{array}$} & \multicolumn{2}{|c|}{$\begin{array}{l}\text { Supplemental } \\
\text { data }\end{array}$} \\
\hline & $\begin{array}{l}\text { Upstream } \\
\text { flow }\end{array}$ & $\begin{array}{l}\text { Tribu- } \\
\text { tary } \\
\text { flow }\end{array}$ & $\begin{array}{l}\text { Stream- } \\
\text { bed } \\
\text { seep- } \\
\text { age }^{3}\end{array}$ & $\begin{array}{l}\text { Evapo- } \\
\text { ration }\end{array}$ & $\begin{array}{l}\text { Reser- } \\
\text { voir } \\
\text { release }\end{array}$ & $\begin{array}{l}\text { Canal } \\
\text { return } \\
\text { flow }\end{array}$ & $\begin{array}{l}\text { Sur- } \\
\text { face- } \\
\text { water } \\
\text { diver- } \\
\text { slons } 7\end{array}$ & $\begin{array}{c}\text { Water- } \\
\text { budget } \\
\text { estimate }\end{array}$ & $\begin{array}{l}\text { Mea- } \\
\text { sured } \\
\text { down- } \\
\text { stream } \\
\text { flow }^{9}\end{array}$ & $\begin{array}{c}\text { Differ- } \\
\text { ence } \\
\text { be- } \\
\text { tween } \\
\text { water- } \\
\text { budget } \\
\text { estl- } \\
\text { mate } \\
\text { and } \\
\text { down- } \\
\text { stream } \\
\text { flow }{ }^{10}\end{array}$ & $\begin{array}{l}\text { Mini- } \\
\text { mum } \\
\text { desir- } \\
\text { able } \\
\text { stream- } \\
\text { flow at } \\
\text { Concor- } \\
\text { dia, } \\
\text { Kansas } \\
11\end{array}$ & $\begin{array}{c}\text { Preclp- } \\
\text { itation } \\
\text { at Con- } \\
\text { cordia, } \\
\text { Kansas } \\
12\end{array}$ \\
\hline \multicolumn{13}{|c|}{1983 water year-Continued } \\
\hline $83-05$ & 39,862 & 18,358 & 20,579 & 296 & 0 & 0 & 0 & 78,503 & 60,586 & 17,917 & 9,223 & 2.98 \\
\hline $83-06$ & 69,984 & 21,125 & 20,943 & 340 & 4,826 & 372 & 16 & 116,894 & 93,740 & 23,154 & 8,926 & 3.59 \\
\hline $83-07$ & 21,884 & 2,048 & 8,921 & 563 & 0 & 4,299 & 1,894 & 34,695 & 33,085 & 1,610 & 9,223 & .16 \\
\hline $83-08$ & 13,385 & 1,576 & 5,142 & 481 & 0 & 3,590 & 1,151 & 22,061 & 23,481 & $-1,420$ & 9,223 & 2.58 \\
\hline $83-09$ & 23,653 & 5,656 & -829 & 364 & 0 & 804 & 141 & 28,779 & 22,671 & 6,108 & 4,760 & 1.72 \\
\hline \multicolumn{13}{|c|}{1984 water year } \\
\hline $83-10$ & 86,792 & 8,183 & -244 & 148 & 0 & 0 & 0 & 94,583 & 75,389 & 19,194 & 5,227 & 3.60 \\
\hline $83-11$ & 15,961 & 2,122 & 4,663 & 0 & 0 & 0 & 0 & 22,746 & 20,662 & 2,084 & 4,760 & 1.84 \\
\hline $83-12$ & 13,234 & 1,777 & 4,335 & 0 & 0 & 0 & 0 & 19,346 & 19,825 & -479 & 6,149 & .85 \\
\hline $84-01$ & 27,791 & 3,563 & 3,852 & 0 & 0 & 0 & 0 & 36,206 & 36,328 & $-1,122$ & 6,149 & .27 \\
\hline $84-02$ & 28,562 & 8,835 & 6,041 & 0 & 0 & 0 & 0 & 43,438 & 37,381 & 6,057 & 6,942 & .55 \\
\hline $84-03$ & 24,705 & 14,869 & 11,825 & 0 & 2,515 & 0 & 0 & 53,914 & 42,725 & 11,189 & 9,223 & 3.09 \\
\hline $84-04$ & 60,415 & 41,021 & 11,152 & 206 & 10,080 & 0 & 0 & 122,463 & 106,673 & 15,790 & 8,926 & 5.98 \\
\hline $84-05$ & 95,363 & 30,526 & 8,929 & 294 & 9,434 & 0 & 0 & 143,957 & 133,589 & 10,368 & 9,223 & 3.98 \\
\hline $84-06$ & 47,043 & 17,255 & 9,238 & 363 & 10,243 & 128 & 6 & 83,538 & 78,420 & 5,118 & 8,926 & 4.36 \\
\hline $84-07$ & 11,625 & 3,899 & 9,379 & 486 & 413 & 4,135 & 3,548 & 25,417 & 29,334 & $-3,917$ & 9,223 & .11 \\
\hline $84-08$ & 8,940 & 1,917 & 4,997 & 435 & 0 & 3,121 & 2,357 & 16,183 & 22,070 & $-5,887$ & 9,223 & 1.85 \\
\hline 84-09 & 5,504 & 689 & 3,261 & 309 & 0 & 850 & 195 & 9,800 & 10,691 & -891 & 4,760 & 2.50 \\
\hline \multicolumn{13}{|c|}{1985 water year } \\
\hline $84-10$ & 3,350 & 3,989 & 3,262 & 138 & 0 & 0 & 0 & 10,463 & 11,032 & -569 & 5,227 & 2.20 \\
\hline $84-11$ & 7,083 & 1,354 & 1,612 & 0 & 0 & 0 & 0 & 10,049 & 9,523 & 526 & 4,760 & .24 \\
\hline $84-12$ & 18,232 & 4,756 & 1,907 & 0 & 0 & 0 & 0 & 24,895 & 12,189 & 12,706 & 6,149 & 3.60 \\
\hline $85-01$ & 9,517 & 2,151 & 1,974 & 0 & 0 & 0 & 0 & 13,642 & 12,377 & 1,265 & 6,149 & 1.14 \\
\hline $85-02$ & 13,805 & 19,987 & 3,822 & 0 & 0 & 0 & 0 & 37,614 & 37,933 & -319 & 6,942 & .86 \\
\hline $85-03$ & 12,915 & 5,479 & 4,965 & 0 & 0 & 0 & 0 & 23,359 & 24,385 & $-1,026$ & 9,223 & 1.04 \\
\hline $85-04$ & 10,866 & 5,337 & 3,812 & 244 & 0 & 0 & 0 & 19,771 & 17,977 & 1,795 & 8,926 & 2.85 \\
\hline $85-05$ & 41,866 & 47,095 & 7,773 & 348 & 14,823 & 0 & 0 & 111,208 & 86,193 & 25,015 & 9,223 & 3.78 \\
\hline $85-06$ & 13,067 & 8,851 & 7,736 & 336 & 3,862 & 1,129 & 369 & 33,940 & 33,563 & 377 & 8,926 & 3.19 \\
\hline $85-07$ & 15,392 & 5,241 & 9,532 & 433 & 0 & 3,408 & 3,305 & 29,835 & 33,916 & $-4,081$ & 9,223 & 2.06 \\
\hline $85-08$ & 42,485 & 27,998 & 21,124 & 293 & 11,508 & 1,148 & 411 & 103,559 & 100,926 & 2,633 & 9,223 & 4.46 \\
\hline $85-09$ & 14,571 & 4,828 & 6,266 & 201 & 5,274 & 490 & 157 & 31,071 & 30,201 & 870 & 4,760 & 2.46 \\
\hline \multicolumn{13}{|c|}{1986 water year } \\
\hline $85-10$ & 15,352 & 8,384 & 6,750 & 155 & 2,037 & 0 & 0 & 32,368 & 28,931 & 3,437 & 5,227 & 2.96 \\
\hline $85-11$ & 12,097 & 4,398 & 3,247 & 0 & 0 & 0 & 0 & 19,742 & 16,195 & 3,547 & 4,760 & .55 \\
\hline
\end{tabular}


Table 5. Monthly, monthly average for water years, and average monthly water-budget estimates of components of flow and of streamflow in the Republican River from near Hardy, Nebraska, to Concordia, Kansas, compared to measured downstream flow, minimum desirable streamflow, and precipitation at Concordia, Kansas, October 1980-September 1995-Continued

\begin{tabular}{|c|c|c|c|c|c|c|c|c|c|c|c|c|}
\hline \multirow[b]{2}{*}{$\begin{array}{c}\text { Date } \\
\text { (year- } \\
\text { month) }\end{array}$} & \multicolumn{4}{|c|}{$\begin{array}{c}\text { Components that are less affected by } \\
\text { human activities }\end{array}$} & \multicolumn{3}{|c|}{$\begin{array}{l}\text { Components that are } \\
\text { more affected by } \\
\text { human activities }\end{array}$} & \multicolumn{3}{|c|}{$\begin{array}{l}\text { Estimated and measured } \\
\text { streamflow }\end{array}$} & \multicolumn{2}{|c|}{$\begin{array}{l}\text { Supplemental } \\
\text { data }\end{array}$} \\
\hline & $\begin{array}{l}\text { Upstream } \\
\text { flow } 1\end{array}$ & $\begin{array}{l}\text { Tribu- } \\
\text { tary } \\
\text { flow }\end{array}$ & $\begin{array}{l}\text { Stream- } \\
\text { bed } \\
\text { seep- } \\
\text { age }^{3}\end{array}$ & $\begin{array}{l}\text { Evapo- } \\
\text { ration } 4\end{array}$ & $\begin{array}{l}\text { Reser- } \\
\text { voir } \\
\text { release }\end{array}$ & $\begin{array}{l}\text { Canal } \\
\text { return } \\
\text { flow }^{6}\end{array}$ & $\begin{array}{l}\text { Sur- } \\
\text { face- } \\
\text { water } \\
\text { diver- } \\
\text { sions } 7\end{array}$ & $\begin{array}{c}\text { Water- } \\
\text { budget } \\
\text { estimate }^{8}\end{array}$ & $\begin{array}{l}\text { Mea- } \\
\text { sured } \\
\text { down- } \\
\text { stream } \\
\text { flow }^{9}\end{array}$ & $\begin{array}{c}\text { Differ- } \\
\text { ence } \\
\text { be- } \\
\text { tween } \\
\text { water- } \\
\text { budget } \\
\text { esti- } \\
\text { mate } \\
\text { and } \\
\text { down- } \\
\text { stream } \\
\text { flow } 10\end{array}$ & $\begin{array}{c}\text { Mini- } \\
\text { mum } \\
\text { desir- } \\
\text { able } \\
\text { stream- } \\
\text { flow at } \\
\text { Concor- } \\
\text { dia, } \\
\text { Kansas } \\
11\end{array}$ & $\begin{array}{c}\text { Precip- } \\
\text { itation } \\
\text { at Con- } \\
\text { cordia, } \\
\text { Kansas } \\
\mathbf{1 2}\end{array}$ \\
\hline \multicolumn{13}{|c|}{1986 water year-Continued } \\
\hline $85-12$ & 11,284 & 4,213 & 2,943 & 0 & 0 & 0 & 0 & 18,440 & 15,436 & 3,004 & 6,149 & 0.42 \\
\hline $86-01$ & 14,753 & 4,420 & 4,264 & 0 & 3,747 & 0 & 0 & 27,184 & 22,610 & 4,574 & 6,149 & 0 \\
\hline $86-02$ & 11,744 & 4,661 & 3,440 & 0 & 0 & 0 & 0 & 19,845 & 16,408 & 3,438 & 6,942 & 1.29 \\
\hline $86-03$ & 12,062 & 3,884 & 4,038 & 0 & 2,969 & 0 & 0 & 22,953 & 18,889 & 4,064 & 9,223 & 2.21 \\
\hline $86-04$ & 17,381 & 9,862 & 3,115 & 272 & 0 & 0 & 0 & 30,086 & 26,835 & 3,251 & 8,926 & 3.11 \\
\hline $86-05$ & 14,410 & 22,903 & 5,380 & 293 & 6,710 & 0 & 0 & 49,110 & 44,992 & 4,118 & 9,223 & 3.63 \\
\hline $86-06$ & 13,141 & 9,406 & 4,914 & 393 & 0 & 2,217 & 1,179 & 28,106 & 23,990 & 4,116 & 8,926 & 5.67 \\
\hline $86-07$ & 12,189 & 5,852 & 7,900 & 465 & 0 & 3,852 & 2,432 & 26,896 & 28,039 & $-1,143$ & 9,223 & 4.69 \\
\hline $86-08$ & 15,939 & 13,056 & 10,638 & 275 & 0 & 1,818 & 522 & 40,654 & 39,799 & 855 & 9,223 & 7.59 \\
\hline $86-09$ & 23,322 & 9,218 & 5,328 & 202 & 0 & 66 & 8 & 37,724 & 41,172 & $-3,448$ & 4,760 & 6.81 \\
\hline \multicolumn{13}{|c|}{1987 water year } \\
\hline $86-10$ & 23,261 & 76,018 & 8,496 & 97 & 21,255 & 0 & 0 & 128,933 & 116,229 & 12,704 & 5,227 & 3.04 \\
\hline $86-11$ & 10,503 & 7,563 & 8,081 & 0 & 4,213 & 0 & 0 & 30,360 & 29,037 & 1,324 & 4,760 & .72 \\
\hline $86-12$ & 12,020 & 13,473 & 7,473 & 0 & 0 & 0 & 0 & 32,966 & 28,039 & 4,927 & 6,149 & 1.42 \\
\hline $87-01$ & 10,893 & 7,202 & 6,615 & 0 & 6,946 & 0 & 0 & 31,657 & 27,727 & 3,930 & 6,149 & .55 \\
\hline $87-02$ & 8,969 & 5,328 & 3,600 & 0 & 0 & 0 & 0 & 17,897 & 16,913 & 984 & 6,942 & .93 \\
\hline $87-03$ & 48,138 & 88,399 & 12,933 & 0 & 1,718 & 0 & 0 & 151,187 & 163,811 & $-12,624$ & 9,223 & 8.32 \\
\hline $87-04$ & 59,870 & 97,125 & 39,733 & 283 & 49,736 & 0 & 0 & 246,181 & 238,556 & 7,625 & 8,926 & 2.90 \\
\hline $87-05$ & 37,835 & 53,362 & 13,552 & 275 & 2,3951 & 0 & 0 & 128,425 & 121,291 & 7,134 & 9,223 & 6.06 \\
\hline $87-06$ & 12,548 & 22,938 & 12,860 & 353 & 728 & 1,454 & 773 & 49,402 & 40,287 & 9,115 & 8,926 & 3.51 \\
\hline $87-07$ & 22,316 & 23,066 & 19,842 & 432 & 0 & 3,659 & 3,343 & 65,108 & 52,844 & 12,264 & 9,223 & 3.45 \\
\hline $87-08$ & 20,589 & 3,799 & 7,035 & 333 & 0 & 1,968 & 1,038 & 32,020 & 28,511 & 3,509 & 9,223 & 3.42 \\
\hline $87-09$ & 8,116 & 1,393 & 2,394 & 210 & 0 & 397 & 37 & 12,053 & 13,504 & $-1,451$ & 4,760 & 1.55 \\
\hline \multicolumn{13}{|c|}{1988 water year } \\
\hline $87-10$ & 7,902 & 1,366 & 1,504 & 164 & 0 & 0 & 0 & 10,608 & 10,893 & -285 & 5,227 & 1.94 \\
\hline $87-11$ & 9,707 & 2,388 & 2,288 & 0 & 0 & 0 & 0 & 14,383 & 13,169 & 1,215 & 4,760 & .72 \\
\hline $87-12$ & 11,978 & 3,620 & 3,043 & 0 & 0 & 0 & 0 & 18,641 & 15,751 & 2,890 & 6,149 & .79 \\
\hline $88-01$ & 11,417 & 5,734 & 3,655 & 0 & 0 & 0 & 0 & 20,806 & 17,578 & 3,228 & 6,149 & .72 \\
\hline $88-02$ & 14,771 & 7,649 & 6,757 & 0 & 5,484 & 0 & 0 & 34,661 & 29,610 & 5,051 & 6,942 & .62 \\
\hline $88-03$ & 12,093 & 3,039 & 3,802 & 0 & 2,281 & 0 & 0 & 21,215 & 18,808 & 2,408 & 9,223 & .55 \\
\hline $88-04$ & 9,144 & 3,086 & 2,591 & 265 & 0 & 0 & 0 & 14,556 & 14,125 & 432 & 8,926 & .99 \\
\hline $88-05$ & 6,930 & 1,561 & 2,997 & 399 & 0 & 0 & 0 & 11,089 & 10,640 & 450 & 9,223 & 2.91 \\
\hline $88-06$ & 3,126 & 1,310 & 2,600 & 512 & 0 & 2,215 & 2,133 & 6,606 & 10,132 & $-3,526$ & 8,926 & 3.16 \\
\hline $88-07$ & 31,964 & 13,973 & 5,166 & 403 & 0 & 2,930 & 2,107 & 51,523 & 42,744 & 8,779 & 9,223 & 1.65 \\
\hline
\end{tabular}


Table 5. Monthly, monthly average for water years, and average monthly water-budget estimates of components of flow and of streamflow in the Republican River from near Hardy, Nebraska, to Concordia, Kansas, compared to measured downstream flow, minimum desirable streamflow, and precipitation at Concordia, Kansas, October 1980-September 1995-Continued

\begin{tabular}{|c|c|c|c|c|c|c|c|c|c|c|c|c|}
\hline \multirow[b]{2}{*}{$\begin{array}{l}\text { Date } \\
\text { (year- } \\
\text { month) }\end{array}$} & \multicolumn{4}{|c|}{$\begin{array}{c}\text { Components that are less affected by } \\
\text { human activities }\end{array}$} & \multicolumn{3}{|c|}{$\begin{array}{l}\text { Components that are } \\
\text { more affected by } \\
\text { human activities }\end{array}$} & \multicolumn{3}{|c|}{$\begin{array}{l}\text { Estimated and measured } \\
\text { streamflow }\end{array}$} & \multicolumn{2}{|c|}{$\begin{array}{l}\text { Supplemental } \\
\text { data }\end{array}$} \\
\hline & $\begin{array}{l}\text { Upstream } \\
\text { flow }^{1}\end{array}$ & $\begin{array}{l}\text { Tribu- } \\
\text { tary } \\
\text { flow }\end{array}$ & $\begin{array}{l}\text { Stream- } \\
\text { bed } \\
\text { seep- } \\
\text { age }^{3}\end{array}$ & $\begin{array}{l}\text { Evapo- } \\
\text { ration } 4\end{array}$ & $\begin{array}{l}\text { Reser- } \\
\text { voir } \\
\text { release }\end{array}$ & $\begin{array}{c}\text { Canal } \\
\text { return } \\
\text { flow }^{6}\end{array}$ & $\begin{array}{l}\text { Sur- } \\
\text { face- } \\
\text { water } \\
\text { diver- } \\
\text { sions } 7\end{array}$ & $\begin{array}{c}\text { Water- } \\
\text { budget } \\
\text { estimate }^{8}\end{array}$ & $\begin{array}{l}\text { Mea- } \\
\text { sured } \\
\text { down- } \\
\text { stream } \\
\text { flow }^{9}\end{array}$ & $\begin{array}{c}\text { Differ- } \\
\text { ence } \\
\text { be- } \\
\text { tween } \\
\text { water- } \\
\text { budget } \\
\text { esti- } \\
\text { mate } \\
\text { and } \\
\text { down- } \\
\text { stream } \\
\text { flow }{ }^{10}\end{array}$ & $\begin{array}{c}\text { Mini- } \\
\text { mum } \\
\text { desir- } \\
\text { able } \\
\text { stream- } \\
\text { flow at } \\
\text { Concor- } \\
\text { dla, } \\
\text { Kansas } \\
11\end{array}$ & $\begin{array}{c}\text { Precip- } \\
\text { itation } \\
\text { at Con- } \\
\text { cordia, } \\
\text { Kansas } \\
12\end{array}$ \\
\hline \multicolumn{13}{|c|}{1988 water year-Continued } \\
\hline $88-08$ & 14,412 & 998 & 4,198 & 370 & 0 & 3,000 & 1,830 & 20,408 & 20,244 & 164 & 9,223 & 1.67 \\
\hline $88-09$ & 4,302 & 186 & 2,807 & 235 & 0 & 746 & 98 & 7,708 & 7,702 & 6 & 4,760 & 1.06 \\
\hline \multicolumn{13}{|c|}{1989 water year } \\
\hline $88-10$ & 3,273 & 135 & 2,409 & 130 & 0 & 0 & 0 & 5,687 & 5,149 & 538 & 5,227 & .04 \\
\hline $88-11$ & 6,181 & 320 & 2,491 & 0 & 0 & 0 & 0 & 8,992 & 8,307 & 685 & 4,760 & .54 \\
\hline $88-12$ & 7,139 & 471 & 2,006 & 0 & 0 & 0 & 0 & 9,616 & 9,213 & 403 & 6,149 & .63 \\
\hline $89-01$ & 7,273 & 571 & 1,797 & 0 & 0 & 0 & 0 & 9,641 & 9,870 & -229 & 6,149 & .56 \\
\hline $89-02$ & 7,992 & 492 & 1,866 & 0 & 0 & 0 & 0 & 10,350 & 7,214 & 3,136 & 6,942 & .56 \\
\hline $89-03$ & 8,678 & 734 & 1,614 & 0 & 0 & 0 & 0 & 11,026 & 10,848 & 178 & 9,223 & .55 \\
\hline $89-04$ & 5,590 & 538 & 2,493 & 319 & 0 & 0 & 0 & 8,302 & 7,240 & 1,062 & 8,926 & .37 \\
\hline $89-05$ & 2,120 & 1,487 & 2,227 & 313 & 0 & 0 & 0 & 5,521 & 5,921 & -400 & 9,223 & 4.06 \\
\hline $89-06$ & 4,364 & 7,643 & 1,720 & 327 & 0 & 721 & 131 & 13,990 & 13,766 & 225 & 8,926 & 5.80 \\
\hline $89-07$ & 29,638 & 15,673 & 5,761 & 381 & 0 & 3,050 & 2,854 & 50,887 & 40,963 & 9,924 & 9,223 & 1.40 \\
\hline $89-08$ & 10,842 & 11,811 & 4,445 & 319 & 0 & 2,578 & 1,861 & 27,496 & 30,395 & $-2,899$ & 9,223 & 5.77 \\
\hline $89-09$ & 3,721 & 21,927 & 4,571 & 191 & 0 & 0 & 0 & 30,028 & 33,499 & $-3,471$ & 4,760 & 4.22 \\
\hline \multicolumn{13}{|c|}{1990 water year } \\
\hline $89-10$ & 5,225 & 294 & 2,631 & 0 & 0 & 0 & 0 & 8,150 & 7,728 & 422 & 5,227 & 1.11 \\
\hline $89-11$ & 6,333 & 469 & 1,908 & 0 & 0 & 0 & 0 & 8,710 & 8,513 & 197 & 4,760 & 0 \\
\hline $89-12$ & 5,234 & 497 & 1,456 & 0 & 0 & 0 & 0 & 7,187 & 6,932 & 255 & 6,149 & .42 \\
\hline $90-01$ & 7,698 & 701 & 1,363 & 0 & 0 & 0 & 0 & 9,762 & 10,308 & -546 & 6,149 & .26 \\
\hline $90-02$ & 5,470 & 769 & 1,868 & 0 & 0 & 0 & 0 & 8,107 & 8,192 & -85 & 6,942 & .43 \\
\hline $90-03$ & 5,181 & 2,322 & 2,191 & 0 & 0 & 0 & 0 & 9,694 & 9,568 & 126 & 9,223 & 4.05 \\
\hline $90-04$ & 8,089 & 1,332 & 1,334 & 206 & 0 & 0 & 0 & 10,549 & 10,160 & 390 & 8,926 & 1.15 \\
\hline $90-05$ & 8,904 & 20,032 & 3,338 & 259 & 0 & 0 & 0 & 32,015 & 31,476 & 539 & 9,223 & 6.37 \\
\hline $90-06$ & 17,737 & 13,073 & 4,300 & 417 & 0 & 611 & 119 & 35,185 & 33,321 & 1,864 & 8,926 & 3.78 \\
\hline $90-07$ & 11,181 & 10,223 & 3,896 & 402 & 0 & 3,316 & 3,022 & 25,192 & 23,990 & 1,202 & 9,223 & 3.96 \\
\hline $90-08$ & 30,116 & 8,269 & 4,217 & 305 & 0 & 3,201 & 2,068 & 43,430 & 41,838 & 1,592 & 9,223 & 1.48 \\
\hline $90-09$ & 4,395 & 49 & 2,275 & 226 & 0 & 1,317 & 441 & 7,370 & 9,311 & $-1,941$ & 4,760 & 1.23 \\
\hline \multicolumn{13}{|c|}{1991 water year } \\
\hline $90-10$ & 2,150 & 98 & 1,726 & 172 & 0 & 0 & 0 & 3,802 & 3,955 & -153 & 5,227 & 1.06 \\
\hline $90-11$ & 2,138 & 200 & 1,273 & 0 & 0 & 0 & 0 & 3,611 & 3,495 & 116 & 4,760 & 1.45 \\
\hline $90-12$ & 2,172 & 207 & 961 & 0 & 0 & 0 & 0 & 3,340 & 3,420 & -80 & 6,149 & .45 \\
\hline $91-01$ & 3,800 & 465 & 1,542 & 0 & 0 & 0 & 0 & 5,807 & 5,260 & 547 & 6,149 & .58 \\
\hline $91-02$ & 8,255 & 1,905 & 2,003 & 0 & 0 & 0 & 0 & 12,163 & 11,151 & 1,012 & 6,942 & .15 \\
\hline
\end{tabular}


Table 5. Monthly, monthly average for water years, and average monthly water-budget estimates of components of flow and of streamflow in the Republican River from near Hardy, Nebraska, to Concordia, Kansas, compared to measured downstream flow, minimum desirable streamflow, and precipitation at Concordia, Kansas, October 1980-September 1995-Continued

\begin{tabular}{|c|c|c|c|c|c|c|c|c|c|c|c|c|}
\hline \multirow[b]{2}{*}{$\begin{array}{l}\text { Date } \\
\text { (year- } \\
\text { month) }\end{array}$} & \multicolumn{4}{|c|}{$\begin{array}{c}\text { Components that are less affected by } \\
\text { human activities }\end{array}$} & \multicolumn{3}{|c|}{$\begin{array}{l}\text { Components that are } \\
\text { more affected by } \\
\text { human activities }\end{array}$} & \multicolumn{3}{|c|}{$\begin{array}{l}\text { Estimated and measured } \\
\text { streamflow }\end{array}$} & \multicolumn{2}{|c|}{$\begin{array}{l}\text { Supplemental } \\
\text { data }\end{array}$} \\
\hline & $\begin{array}{l}\text { Upstream } \\
\text { flow } 1\end{array}$ & $\begin{array}{l}\text { Tribu- } \\
\text { tary } \\
\text { flow }\end{array}$ & $\begin{array}{l}\text { Stream- } \\
\text { bed } \\
\text { seep- } \\
\text { age }^{3}\end{array}$ & $\begin{array}{l}\text { Evapo- } \\
\text { ration } 4\end{array}$ & $\begin{array}{l}\text { Reser- } \\
\text { voir } \\
\text { release }^{5}\end{array}$ & $\begin{array}{l}\text { Canal } \\
\text { return } \\
\text { flow }^{6}\end{array}$ & $\begin{array}{l}\text { Sur- } \\
\text { face- } \\
\text { water } \\
\text { diver- } \\
\text { sions } 7\end{array}$ & $\begin{array}{c}\text { Water- } \\
\text { budget } \\
\text { estimate }\end{array}$ & $\begin{array}{l}\text { Mea- } \\
\text { sured } \\
\text { down- } \\
\text { stream } \\
\text { flow }^{9}\end{array}$ & $\begin{array}{c}\text { Differ- } \\
\text { ence } \\
\text { be- } \\
\text { tween } \\
\text { water- } \\
\text { budget } \\
\text { esti- } \\
\text { mate } \\
\text { and } \\
\text { down- } \\
\text { stream } \\
\text { flow }{ }^{10}\end{array}$ & $\begin{array}{c}\text { Mini- } \\
\text { mum } \\
\text { desir- } \\
\text { able } \\
\text { stream- } \\
\text { flow at } \\
\text { Concor- } \\
\text { dia, } \\
\text { Kansas } \\
11\end{array}$ & $\begin{array}{l}\text { Precip- } \\
\text { itation } \\
\text { at Con- } \\
\text { cordia, } \\
\text { Kansas } \\
12\end{array}$ \\
\hline \multicolumn{13}{|c|}{1991 water year-Continued } \\
\hline $91-03$ & 4,274 & 1,580 & 2,214 & 0 & 0 & 0 & 0 & 8,068 & 6,538 & 1,530 & 9,223 & 2.14 \\
\hline $91-04$ & 2,313 & 3,214 & 1,613 & 220 & 0 & 0 & 0 & 6,920 & 4,514 & 2,406 & 8,926 & 1.98 \\
\hline $91-05$ & 5,361 & 5,943 & 1,910 & 262 & 0 & 0 & 0 & 12,952 & 6,849 & 6,103 & 9,223 & 3.02 \\
\hline $91-06$ & 14,236 & 6,333 & 2,917 & 401 & 10 & 1,073 & 1,261 & 22,907 & 26,918 & $-4,011$ & 8,926 & 3.77 \\
\hline $91-07$ & 3,320 & 17 & 2,770 & 461 & 0 & 2,596 & 3,612 & 4,630 & 5,435 & -805 & 9,223 & .86 \\
\hline $91-08$ & 3,600 & 7 & 1,455 & 355 & 0 & 1,233 & 1,463 & 4,478 & 5,282 & -804 & 9,223 & 2.60 \\
\hline $91-09$ & 920 & 3 & 73 & 303 & 0 & 0 & 0 & 694 & 1,864 & $-1,170$ & 4,760 & .21 \\
\hline \multicolumn{13}{|c|}{1992 water year } \\
\hline $91-10$ & 1,033 & 0 & -213 & 218 & 0 & 0 & 0 & 603 & 895 & -292 & 5,227 & 1.49 \\
\hline $91-11$ & 1,333 & 9 & 259 & 0 & 0 & 0 & 0 & 1,601 & 2,021 & -420 & 4,760 & 1.50 \\
\hline $91-12$ & 1,595 & 51 & 1,126 & 0 & 0 & 0 & 0 & 2,771 & 3,013 & -242 & 6,149 & 1.65 \\
\hline $92-01$ & 2,075 & 127 & 2,081 & 0 & 0 & 0 & 0 & 4,283 & 4,267 & 16 & 6,149 & .73 \\
\hline $92-02$ & 1,551 & 94 & 1,906 & 0 & 0 & 0 & 0 & 3,551 & 3,550 & 1 & 6,942 & .88 \\
\hline $92-03$ & 4,417 & 485 & 2,048 & 0 & 0 & 0 & 0 & 6,950 . & 5,794 & 1,156 & 9,223 & 2.06 \\
\hline $92-04$ & 3,739 & 645 & 1,989 & 227 & 0 & 0 & 0 & 6,146 & 5,798 & 348 & 8,926 & 2.58 \\
\hline $92-05$ & 1,835 & 141 & 1,302 & 334 & 0 & 0 & 0 & 2,944 & 3,148 & -204 & 9,223 & 3.49 \\
\hline $92-06$ & 2,793 & 9,132 & 2,029 & 267 & 0 & 103 & 156 & 13,634 & 26,139 & $-12,505$ & 8,926 & 6.31 \\
\hline $92-07$ & 56,551 & 72,720 & 6,716 & 343 & 3,751 & 462 & 697 & 139,160 & 121,959 & 17,201 & 9,223 & 11.43 \\
\hline $92-08$ & 15,253 & 22,756 & 9,540 & 297 & 10,044 & 344 & 212 & 57,429 & 36,986 & 20,443 & 9,223 & 2.63 \\
\hline $92-09$ & 8,549 & 9,129 & 2,368 & 246 & 7,385 & 15 & 11 & 27,188 & 28,053 & -865 & 4,760 & 2.69 \\
\hline \multicolumn{13}{|c|}{1993 water year } \\
\hline $92-10$ & 7,396 & 14,355 & 2,639 & 106 & 0 & 0 & 0 & 24,284 & 38,700 & $-14,416$ & 5,227 & 4.89 \\
\hline $92-11$ & 7,589 & 5,568 & 3,471 & 0 & 0 & 0 & 0 & 16,628 & 17,356 & -728 & 4,760 & 2.17 \\
\hline $92-12$ & 7,488 & 10,710 & 5,777 & 0 & 0 & 0 & 0 & 23,975 & 27,029 & $-3,054$ & 6,149 & 1.66 \\
\hline $93-01$ & 6,982 & 4,400 & 2,666 & 0 & 0 & 0 & 0 & 14,048 & 14,559 & -511 & 6,149 & 1.52 \\
\hline $93-02$ & 28,527 & 43,204 & 7,541 & 0 & 6,665 & 0 & 0 & 85,936 & 72,045 & 13,891 & 6,942 & 1.33 \\
\hline $93-03$ & 96,265 & 82,649 & 4,610 & 0 & 22,503 & 0 & 0 & 206,027 & 170,095 & 35,932 & 9,223 & 2.63 \\
\hline $93-04$ & 33,345 & 32,370 & 6,168 & 161 & 4,669 & 0 & 0 & 76,391 & 56,407 & 19,984 & 8,926 & 1.95 \\
\hline $93-05$ & 28,406 & 32,092 & 13,256 & 218 & 1,394 & 0 & 0 & 74,930 & 45,204 & 29,726 & 9,223 & 3.41 \\
\hline $93-06$ & 19,682 & 47,812 & 12,917 & 342 & 3,045 & 116 & 2 & 83,228 & 64,208 & 19,020 & 8,926 & 6.66 \\
\hline $93-07$ & 195,740 & 269,730 & 76,108 & 294 & 45,160 & 1,467 & 0 & 587,911 & 660,321 & $-72,410$ & 9,223 & 16.75 \\
\hline $93-08$ & 48,274 & 45,255 & 17,317 & 263 & 45,984 & 2,017 & 505 & 158,079 & 144,617 & 13,462 & 9,223 & 4.77 \\
\hline $93-09$ & 74,621 & 28,153 & 11,532 & 179 & 16,529 & 106 & 22 & 130,740 & 103,682 & 27,058 & 4,760 & 3.12 \\
\hline
\end{tabular}


Table 5. Monthly, monthly average for water years, and average monthly water-budget estimates of components of flow and of streamflow in the Republican River from near Hardy, Nebraska, to Concordia, Kansas, compared to measured downstream flow, minimum desirable streamflow, and precipitation at Concordia, Kansas, October 1980-September 1995-Continued

\begin{tabular}{|c|c|c|c|c|c|c|c|c|c|c|c|c|}
\hline \multirow[b]{2}{*}{$\begin{array}{l}\text { Date } \\
\text { (year- } \\
\text { month) }\end{array}$} & \multicolumn{4}{|c|}{$\begin{array}{c}\text { Components that are less affected by } \\
\text { human activities }\end{array}$} & \multicolumn{3}{|c|}{$\begin{array}{l}\text { Components that are } \\
\text { more affected by } \\
\text { human activities. }\end{array}$} & \multicolumn{3}{|c|}{$\begin{array}{l}\text { Estimated and measured } \\
\text { streamflow }\end{array}$} & \multicolumn{2}{|c|}{$\begin{array}{l}\text { Supplemental } \\
\text { data }\end{array}$} \\
\hline & $\begin{array}{l}\text { Upstream } \\
\text { flow }\end{array}$ & $\begin{array}{l}\text { Tribu- } \\
\text { tary } \\
\text { flow }\end{array}$ & $\begin{array}{c}\text { Stream- } \\
\text { bed } \\
\text { seep- } \\
\text { age }^{3}\end{array}$ & $\begin{array}{l}\text { Evapo- } \\
\text { ration }\end{array}$ & $\begin{array}{l}\text { Reser- } \\
\text { voir } \\
\text { release }^{5}\end{array}$ & $\begin{array}{l}\text { Canal } \\
\text { return } \\
\text { flow }^{6}\end{array}$ & $\begin{array}{l}\text { Sur- } \\
\text { face- } \\
\text { water } \\
\text { diver- } \\
\text { sions }\end{array}$ & $\begin{array}{l}\text { Water- } \\
\text { budget } \\
\text { estimate }^{8}\end{array}$ & $\begin{array}{l}\text { Mea- } \\
\text { sured } \\
\text { down- } \\
\text { stream } \\
\text { flow }^{9}\end{array}$ & $\begin{array}{l}\text { Differ- } \\
\text { ence } \\
\text { be- } \\
\text { tween } \\
\text { water- } \\
\text { budget } \\
\text { esti- } \\
\text { mate } \\
\text { and } \\
\text { down- } \\
\text { stream } \\
\text { flow }{ }^{10}\end{array}$ & $\begin{array}{l}\text { Mini- } \\
\text { mum } \\
\text { desir- } \\
\text { able } \\
\text { stream- } \\
\text { flow at } \\
\text { Concor- } \\
\text { dia, } \\
\text { Kansas } \\
11\end{array}$ & $\begin{array}{c}\text { Precip- } \\
\text { itation } \\
\text { at Con- } \\
\text { cordia, } \\
\text { Kansas } \\
12\end{array}$ \\
\hline \multicolumn{13}{|c|}{1994 water year } \\
\hline $93-10$ & 75,413 & 13,024 & 8,850 & 128 & 7,301 & 0 & 0 & 104,460 & 83,599 & 20,861 & 5,227 & 0.86 \\
\hline $93-11$ & 77,872 & 8,970 & 2,592 & 0 & 1,932 & 0 & 0 & 91,366 & 83,922 & 7,444 & 4,760 & .57 \\
\hline $93-12$ & 58,636 & 9,836 & 14,160 & 0 & 5,716 & 0 & 0 & 88,349 & 75,589 & 12,760 & 6,149 & 1.11 \\
\hline $94-01$ & 29,415 & 7,877 & 9,342 & 0 & 2,717 & 0 & 0 & 49,352 & 39,547 & 9,805 & 6,149 & .62 \\
\hline $94-02$ & 28,979 & 6,999 & 8,761 & 0 & 2,414 & 0 & 0 & 47,153 & 39,710 & 7,443 & 6,942 & .53 \\
\hline $94-03$ & 69,557 & 17,331 & 24,037 & 0 & 2,372 & 0 & 0 & 113,298 & 82,956 & 30,342 & 9,223 & .06 \\
\hline $94-04$ & 24,465 & 10,146 & 7,958 & 0 & 470 & 0 & 0 & 43,039 & 33,666 & 9,373 & 8,926 & 1.71 \\
\hline $94-05$ & 22,098 & 12,608 & 9,480 & 319 & 2,551 & 0 & 0 & 46,418 & 31,284 & 15,134 & 9,223 & 1.58 \\
\hline $94-06$ & 8,339 & 11,830 & 4,925 & 353 & 0 & 1,452 & 420 & 25,773 & 22,386 & 3,387 & 8,926 & 5.02 \\
\hline $94-07$ & 16,511 & 13,744 & 8,452 & 364 & 0 & 2,778 & 751 & 40,370 & 38,490 & 1,880 & 9,223 & 3.43 \\
\hline $94-08$ & 8,821 & 2,975 & 4,094 & 309 & 0 & 2,635 & 1,853 & 16,363 & 19,065 & $-2,702$ & 9,223 & 1.02 \\
\hline $94-09$ & 8,483 & 1,169 & 2,259 & 213 & 0 & 39 & 16 & 11,721 & 10,905 & 816 & 4,760 & .98 \\
\hline \multicolumn{13}{|c|}{1995 water year } \\
\hline $94-10$ & 6,780 & 1,160 & 1,571 & 126 & 0 & 0 & 0 & 9,385 & 8,684 & 701 & 5,227 & 1.67 \\
\hline $94-11$ & 8,132 & 1,977 & 1,586 & 0 & 0 & 0 & 0 & 11,695 & 10,953 & 742 & 4,760 & 1.20 \\
\hline $94-12$ & 9,380 & 2,601 & 1,955 & 0 & 0 & 0 & 0 . & 13,936 & 12,316 & 1,620 & 6,149 & 1.33 \\
\hline $95-01$ & 7,236 & 3,440 & 2,054 & 0 & 0 & 0 & 0 & 12,730 & 12,629 & 101 & 6,149 & 1.03 \\
\hline $95-02$ & 7,119 & 2,870 & 2,373 & 0 & 0 & 0 & 0 & 12,362 & 10,721 & 1,641 & 6,942 & .06 \\
\hline $95-03$ & 9,918 & 3,845 & 2,748 & 0 & 0 & 0 & 0 & 16,511 & 14,819 & 1,692 & 9,223 & 2.42 \\
\hline $95-04$ & 10,058 & 3,666 & 2,553 & 163 & 0 & 0 & 0 & 16,114 & 14,006 & 2,109 & 8,926 & 2.19 \\
\hline $95-05$ & 68,417 & 96,336 & 33,640 & 190 & 0 & 0 & 0 & 198,203 & 127,382 & 70,821 & 9,223 & 8.45 \\
\hline $95-06$ & 69,805 & 29,347 & 35,551 & 334 & 6,581 & 202 & 5 & 141,148 & 99,413 & 41,735 & 8,926 & 4.35 \\
\hline $95-07$ & 20,571 & 8,826 & 12,715 & 369 & 0 & 1,470 & 3,015 & 40,198 & 38,891 & 1,308 & 9,223 & 1.56 \\
\hline $95-08$ & 14,299 & 8,249 & 6,794 & 338 & 0 & 2,727 & 2,838 & 28,893 & 31,026 & $-2,133$ & 9,223 & 3.79 \\
\hline $95-09$ & 6,476 & 1,337 & 3,076 & 184 & 0 & 1,052 & 626 & 11,131 & 13,912 & $-2,781$ & 4,760 & 1.88 \\
\hline \multicolumn{13}{|c|}{ Average for water years $1981-95$} \\
\hline $\begin{array}{c}80-10 \\
\text { to } \\
95-09\end{array}$ & 19,477 & 12,368 & 6,220 & 167 & 2,368 & 553 & 353 & 40,466 & 36,740 & 3,726 & 7,394 & 2.47 \\
\hline \multicolumn{13}{|c|}{ Average for water years } \\
\hline 1981 & 10,267 & 5,007 & 2,580 & 186 & 531 & 589 & 280 & 18,503 & 16,426 & 2,077 & 7,394 & 2.70 \\
\hline 1982 & 22,723 & 8,354 & 7,147 & 164 & 1,256 & 665 & 259 & 39,721 & 37,976 & 1,745 & 7,394 & 3.19 \\
\hline 1983 & 25,643 & 8,145 & 9,538 & 201 & 466 & 755 & 267 & 44,079 & 37,125 & 6,954 & 7,394 & 1.85 \\
\hline 1984 & 35,495 & 11,221 & 6,452 & 187 & 2,724 & 686 & 509 & 55,883 & 51,091 & 4,792 & 7,394 & 2.42 \\
\hline
\end{tabular}


Table 5. Monthly, monthly average for water years, and average monthly water-budget estimates of components of flow and of streamflow in the Republican River from near Hardy, Nebraska, to Concordia, Kansas, compared to measured downstream flow, minimum desirable streamflow, and precipitation at Concordia, Kansas, October 1980-September 1995-Continued

\begin{tabular}{|c|c|c|c|c|c|c|c|c|c|c|c|c|}
\hline \multirow[b]{2}{*}{$\begin{array}{l}\text { Date } \\
\text { (year- } \\
\text { month) }\end{array}$} & \multicolumn{4}{|c|}{$\begin{array}{l}\text { Components that are less affected by } \\
\text { human activities }\end{array}$} & \multicolumn{3}{|c|}{$\begin{array}{l}\text { Components that are } \\
\text { more affected by } \\
\text { human activities }\end{array}$} & \multicolumn{3}{|c|}{$\begin{array}{l}\text { Estimated and measured } \\
\text { streamflow }\end{array}$} & \multicolumn{2}{|c|}{$\begin{array}{l}\text { Supplemental } \\
\text { data }\end{array}$} \\
\hline & $\begin{array}{l}\text { Upstream } \\
\text { flow }{ }^{1}\end{array}$ & $\begin{array}{l}\text { Tribu- } \\
\text { tary } \\
\text { flow }^{2}\end{array}$ & $\begin{array}{l}\text { Stream- } \\
\text { bed } \\
\text { seep- } \\
\text { age }^{3}\end{array}$ & $\begin{array}{l}\text { Evapo- } \\
\text { ration } 4\end{array}$ & $\begin{array}{l}\text { Reser- } \\
\text { voir } \\
\text { release }\end{array}$ & $\begin{array}{l}\text { Canal } \\
\text { return } \\
\text { flow }\end{array}$ & $\begin{array}{l}\text { Sur- } \\
\text { face- } \\
\text { water } \\
\text { diver- } \\
\text { sions }\end{array}$ & $\begin{array}{c}\text { Water- } \\
\text { budget } \\
\text { estimate }^{8}\end{array}$ & $\begin{array}{l}\text { Mea- } \\
\text { sured } \\
\text { down- } \\
\text { stream } \\
\text { flow }^{9}\end{array}$ & $\begin{array}{c}\text { Differ- } \\
\text { ence } \\
\text { be- } \\
\text { tween } \\
\text { water- } \\
\text { budget } \\
\text { esti- } \\
\text { mate } \\
\text { and } \\
\text { down- } \\
\text { stream } \\
\text { flow }{ }^{10}\end{array}$ & $\begin{array}{l}\text { Mini- } \\
\text { mum } \\
\text { desir- } \\
\text { able } \\
\text { stream- } \\
\text { flow at } \\
\text { Concor- } \\
\text { dia, } \\
\text { Kansas } \\
11\end{array}$ & $\begin{array}{l}\text { Precip- } \\
\text { itation } \\
\text { at Con- } \\
\text { cordia, } \\
\text { Kansas } \\
{ }_{12}\end{array}$ \\
\hline \multicolumn{13}{|c|}{ Average for water years-Continued } \\
\hline 1985 & 16,929 & 11,422 & 6,149 & 166 & 2,956 & 515 & 354 & 37,451 & 34,184 & 3,266 & 7,394 & 2.32 \\
\hline 1986 & 14,473 & 8,355 & 5,163 & 171 & 1,289 & 663 & 345 & 29,426 & 26,941 & 2,484 & 7,394 & 3.24 \\
\hline 1987 & 22,921 & 33,306 & 11,885 & 165 & 9,046 & 623 & 433 & 77,182 & 73,062 & 4,120 & 7,394 & 2.99 \\
\hline 1988 & 11,479 & 3,743 & 3,451 & 196 & 647 & 741 & 514 & 19,350 & 17,616 & 1,734 & 7,394 & 1.40 \\
\hline 1989 & 8,067 & 5,150 & 2,783 & 165 & 0 & 529 & 404 & 15,961 & 15,199 & 763 & 7,394 & 2.04 \\
\hline 1990 & 9,630 & 4,836 & 2,565 & 151 & 0 & 704 & 471 & 17,113 & 16,778 & 335 & 7,394 & 2.02 \\
\hline 1991 & 4,378 & 1,664 & 1,705 & 181 & 1 & 409 & 528 & 7,448 & 7,057 & 391 & 7,394 & 1.52 \\
\hline 1992 & 8,394 & 9,607 & 2,596 & 161 & 1,765 & 77 & 90 & 22,188 & 20,135 & 2,053 & 7,394 & 3.12 \\
\hline 1993 & 46,193 & 51,358 & 13,667 & 130 & 12,162 & 309 & 44 & 123,515 & 117,852 & 5,663 & 7,394 & 4.24 \\
\hline 1994 & 35,716 & 9,709 & 8,743 & 141 & 2,123 & 575 & 253 & 56,472 & 46,760 & 9,712 & 7,394 & 1.42 \\
\hline 1995 & 19,849 & 13,638 & 8,885 & 142 & 548 & 454 & 540 & 42,692 & 32,896 & 9,796 & 7,394 & 2.49 \\
\hline \multicolumn{13}{|c|}{ Average for month } \\
\hline Oct. & 17,604 & 8,990 & 3,022 & 143 & 2,091 & 0 & 0 & 31,563 & 28,850 & 2,713 & 5,227 & 1.90 \\
\hline Nov. & 12,598 & 2,553 & 2,611 & 0 & 410 & 0 & 0 & 18,171 & 17,168 & 1,003 & 4,760 & 1.02 \\
\hline Dec. & 12,485 & 3,819 & 3,545 & 0 & 515 & 0 & 0 & 20,365 & 18,002 & 2,363 & 6,149 & 1.14 \\
\hline Jan. & 10,910 & 3,017 & 3,116 & 0 & 894 & 0 & 0 & 17,936 & 16,383 & 1,553 & 6,149 & .72 \\
\hline Feb. & 14,262 & 8,156 & 4,001 & 0 & 971 & 0 & 0 & 27,389 & 23,739 & 3,650 & 6,942 & .65 \\
\hline Mar. & 24,673 & 16,683 & 6,983 & 0 & 2,291 & 0 & 0 & 50,630 & 44,408 & 6,222 & 9,223 & 2.44 \\
\hline April & 19,777 & 14,859 & 7,177 & 222 & 4,330 & 0 & 0 & 45,921 & 40,959 & 4,962 & 8,926 & 2.24 \\
\hline May & 31,763 & 25,497 & 9,207 & 292 & 4,027 & 0 & 0 & 70,202 & 56,253 & 13,949 & 9,223 & 4.55 \\
\hline June & 22,518 & 15,835 & 9,474 & 364 & 2,716 & 931 & 488 & 50,623 & 44,209 & 6,414 & 8,926 & 4.74 \\
\hline July & 34,348 & 32,145 & 13,752 & 415 & 3,288 & 2,939 & 2,268 & 83,790 & 85,426 & $-1,636$ & 9,223 & 4.44 \\
\hline Aug. & 18,888 & 10,951 & 8,211 & 335 & 4,887 & 2,314 & 1,349 & 43,567 & 41,264 & 2,303 & 9,223 & 3.36 \\
\hline Sept. & 13,902 & 5,906 & 3,547 & 238 & 1,991 & 451 & 128 & 25,430 & 24,218 & 1,212 & 4,760 & 2.33 \\
\hline
\end{tabular}

${ }^{1}$ Measured streamflow in Republican River near Hardy, Nebraska, after adjusting 1 day for traveltime to Concordia, Kansas. Streamflow data from U.S. Geological Survey, Lawrence, Kansas.

${ }^{2}$ Tributary inflow to Republican River in study area-includes estimated streamflow for Buffalo Creek near Jamestown, Kansas, after May 1990 and estimated unregulated discharge of less than or equal to 10 cubic feet per second for White Rock Creek at Lovewell, Kansas. Streamflow data from U.S. Geological Survey, Lawrence, Kansas. 
${ }^{3}$ Streambed seepage to or from the Republican River. If mean daily streamflow at Concordia, Kansas, was from 150 through 500 cubic feet per second, daily streambed seepage was estimated using a rearranged form of the regression equation of streamflow at Concordia, Kansas, with streambed seepage estimated from 10 synoptic streambed-seepage surveys. The rearranged equation is: streambed seepage $=(D F-100) / 3.155$, where DF is mean daily streamflow at Concordia, Kansas, in cubic feet per second. If mean daily streamflow at Concordia, Kansas, was less than 150 cubic feet per second or greater than 500 cubic feet per second, streambed seepage to or from the Republican River was estimated as streambed seepage at Concordia minus streambed seepage near Hardy, Nebraska, where the streambed seepage at Concordia and near Hardy were computed using the BFI4 computer program (Wahl and Wahl, 1995). Streambed seepage for near Hardy was computed after adjusting 1 day for traveltime; streambed seepage for Concordia computed after subtracting the part of the average daily releases from Lovewell Reservoir greater than 10 cubic feet per second and adjusted 2 days for traveltime to Concordia. The BFI4 program was used with minimum increment testing interval (N) equal to 7 days and the turning point factor (f) equal to 0.90 .

Streamflow data from U.S. Geological Survey, Lawrence, Kansas.

${ }^{4}$ Evaporation from the Republican River in study area. Estimated by multiplying monthly pan evaporation (in inches) measured at Lovewell Reservoir by the pan-evaporation coefficient for north-central Kansas $(0.72)$ by the estimated length ( 42.7 miles) and width (150 feet) of the Republican River in the study area. Sources: pan evaporation data from National Oceanic and Atmospheric Administration, 1980-96; pan evaporation coefficient from Farnsworth and others, 1982.

${ }^{5}$ Releases from Lovewell Reservoir. Estimated as mean daily streamflow greater than 10 cubic feet per second measured at gaging station on White Rock Creek at Lovewell, Kansas. Streamflow data from U.S. Geological Survey, Lawrence, Kansas.

${ }^{6}$ Canal return flow to Republican River reported by Kansas Bostwick Irrigation District. Source: Kansas Bostwick Irrigation District, Courtland, Kansas.

${ }^{7}$ Surface-water diversions from Republican River and tributaries in ungaged part of study area, proportioned the same as Kansas Bostwick Irrigation District farm deliveries. Surface-water diversion data from Kansas Department of Agriculture, Division of Water Resources; farm delivery data from Kansas Bostwick Irrigation District, Courtland, Kansas.

${ }^{8}$ Water-budget estimate of streamflow in Republican River at Concordia, Kansas. Estimated as sum of upstream flow, tributary flow, streambed seepage, reservoir release, and canal return flow minus evaporation and surface-water diversions.

${ }^{9}$ Measured streamflow in Republican River at Concordia, Kansas. Streamflow data from U.S. Geological Survey, Lawrence, Kansas.

${ }^{10}$ Error in water-budget estimate of downstream flow (at Concordia, Kansas); negative value is underestimate, positive value is overestimate.

"Set by Kansas law K.S.A. 82a-703a, 1984.

${ }^{12}$ Precipitation data from National Climatic Data Center, Asheville, North Carolina. 
